\title{
Novel mechanisms regulating Notch signaling
}

\author{
Citation for published version (APA):
}

Hounjet, J. (2021). Novel mechanisms regulating Notch signaling: the importance of intracellular vesicles: "When Notch, a metal transporter, and an antimalarial drug meet...". [Doctoral Thesis, Maastricht University]. ProefschriftMaken. https://doi.org/10.26481/dis.20210609jh

\section{Document status and date:}

Published: 01/01/2021

DOI:

10.26481/dis.20210609jh

Document Version:

Publisher's PDF, also known as Version of record

\section{Please check the document version of this publication:}

- A submitted manuscript is the version of the article upon submission and before peer-review. There can be important differences between the submitted version and the official published version of record.

People interested in the research are advised to contact the author for the final version of the publication, or visit the DOI to the publisher's website.

- The final author version and the galley proof are versions of the publication after peer review.

- The final published version features the final layout of the paper including the volume, issue and page numbers.

Link to publication

\footnotetext{
General rights rights.

- You may freely distribute the URL identifying the publication in the public portal. please follow below link for the End User Agreement:

www.umlib.nl/taverne-license

Take down policy

If you believe that this document breaches copyright please contact us at:

repository@maastrichtuniversity.nl

providing details and we will investigate your claim.
}

Copyright and moral rights for the publications made accessible in the public portal are retained by the authors and/or other copyright owners and it is a condition of accessing publications that users recognise and abide by the legal requirements associated with these

- Users may download and print one copy of any publication from the public portal for the purpose of private study or research.

- You may not further distribute the material or use it for any profit-making activity or commercial gain

If the publication is distributed under the terms of Article $25 \mathrm{fa}$ of the Dutch Copyright Act, indicated by the "Taverne" license above, 


\section{Novel mechanisms regulating Notch signaling; the importance of intracellular vesicles}

"When Notch, a metal transporter, and an antimalarial drug meet..." 
(C) copyright Judith Hounjet, Maastricht 2021

Printing: ProefschriftMaken || www.proefschriftmaken.nl

All rights reserved. No part of this thesis may be reproduced or distributed in any form or by any means, without the prior written permission of the author or publisher.

ISBN: 978-94-6423-149-6 


\section{Novel mechanisms regulating Notch signaling; the importance of intracellular vesicles}

"When Notch, a metal transporter, and an antimalarial drug meet..."

\section{DISSERTATION}

To obtain the degree of Doctor at Maastricht University, on the authority of the Rector Magnificus, Prof. Dr. Rianne M. Letschert in accordance with the decision of the Board of Deans, to be defended in public on Wednesday June $9^{\text {th }} 2021$ at $16: 00$ hours

by Judith Sophia Johanna Maria Hounjet 
Promoter:

Co-promoter:

Assessment committee:
Prof. dr. M.A.G.G. Vooijs

Dr. ing. A.J. Groot
Prof. dr. L. de Windt (UM, Chair)

Prof. dr. M. Maurice (UMC, Utrecht)

Dr. A. Romano (UM)

Prof. dr. F. Reggiori (UMC, Groningen) 


\section{Table of contents}

Chapter I Introduction and outline of this thesis 7

Chapter II The role of intracellular trafficking of Notch 45

receptors in Notch signaling activation

Chapter III The antimalarial drug chloroquine sensitizes

97

oncogenic NOTCH1 driven human T-ALL to $Y$-secretase inhibition

Chapter IV The isoforms of Divalent metal transporter 1 (Dmt1) differentially control Notch-mediated cell fate decisions

Chapter V Summary and General discussion

Nederlandse samenvatting

Reflection

223

Acknowledgements/Dankwoord

Curriculum Vitae

List of publications

245 


$$
\begin{aligned}
& \text { CHAPTER I } \\
& \text { CHAP TER }
\end{aligned}
$$




\section{Introduction}

\section{Judith Hounjet}

Department of Radiation Oncology (Maastro), GROW School for Oncology, Maastricht University Medical Centre+, Maastricht, The Netherlands

Maastro clinic, Maastricht, The Netherlands 


\section{Cancer}

Cancer is the second leading cause of death worldwide. Each year approximately 10 million people die of cancer (World Health Organization). Since cancer has such a great impact on human mortality, worldwide billions were spent on cancer research over the last 50 years since the National Cancer Act of 1971 was signed. The National Cancer Act declared the "war on cancer" to find a cure for cancer by increasing cancer research in understanding the molecular biology and developing more effective cancer treatments. Although mortality rates are (slightly) declining in most higher-income countries, these trends are lacking in lower-income countries (World Cancer Report, WHO). How can it be that one disease kills so many people each year? Why is this disease not cured after spending millions each year?

Most importantly, cancer is often depicted as one disease. However, cancer is a name for a collection of over a hundred distinct, but related, diseases in which cells of a specific tissue of the human body show uncontrolled growth. As cancer can affect almost each tissue of the human body and within specific tissues different cancers can arise, cancer is not one disease and can simply not be cured with a single drug. Besides, tumor cells deregulate processes in the human body that are used during development and maintenance of adult tissues. As these processes are also required by normal tissues for proper homeostasis, extensive research is required to be able to develop "smart" therapeutics targeting cancer cells, without damaging normal tissues.

\section{Hallmarks of cancer}

Cancer research has generated comprehensive knowledge on the molecular mechanisms of cancer over the last decades. The foundation in the understanding of cancer has been set by the discovery of cancer specific mutations leading to gainof-function of oncogenes, stimulating proliferation and growth, and the loss-offunction of tumor suppressors, which inhibit uncontrolled proliferation and stimulate cell death. Although each cancer acts differently general cancer hallmarks, which are essential and common to all cancers for the initiation and progression of tumor cells, have been introduced 20 years ago. These cancer hallmarks include: self-sufficiency 
in growth signals, insensitivity to growth inhibitory signals, evasion of programmed cell death, limitless replicative potential, sustained angiogenesis, and tissue invasion and metastases (Hanahan and Weinberg, 2000). Genetic reprogramming of cancer cells results in increased proliferation by enhanced production of growth signals, cell cycle checkpoint inhibition by suppression of p53, and reduced induction of programmed cell death, due to increased anti-apoptotic signals. In addition, angiogenesis, the formation of new blood vessels, is activated by an angiogenic switch during tumor progression to supply oxygen and nutrients for further tumor growth and survival. During tumor progression tumor cells can invade and metastasize to distant sites, due to modulation of the surrounding tissues including degradation of cell-cell adhesion molecules and modulation of the extracellular matrix.

Over the last decades, additional hallmarks of cancer were discovered, including reprogramming of energy metabolism and genomic instability to sustain proliferation of tumor cells. Additional hallmarks of cancer cells are evasion of the immune system by modulation of T-cells, B-cells, macrophages, and natural killer cells leading to reduced anti-tumor immune responses. Lastly, tumor cells promote inflammation resulting in increased production of growth, survival, and proangiogenic factors and invasion stimulating processes, supporting tumorigenesis and tumor progression (Hanahan and Weinberg, 2011).

\section{Tumor microenvironment}

Despite the fact that these general hallmarks of cancer make the molecular understanding of tumors complex an additional layer of complexity is applied by the tumor microenvironment. The tumor microenvironment is composed of proliferating tumor cells, surrounding blood vessels, extracellular matrix and non-malignant cells, including: stromal cells, fibroblasts, immune cells, pericytes and adipocytes, which all contribute to the hallmarks of cancer. Stromal cells and cancer-associated fibroblasts (CAFs) produce mitogenic signals, including growth factors and chemokines, which stimulate the proliferation and survival of tumor cells (Hanahan and Coussens, 2012), leading to poor patient prognosis (Räsänen and Vaheri, 2010). 
In addition, CAFs remodel the extracellular matrix (ECM) by producing proteolytic enzymes, including matrix metalloproteinases (MMPs), and regulation of ECM synthesis, promoting tumor growth and invasion and induce angiogenesis by the secretion of pro-angiogenic factors and ECM degradation (Hanahan and Coussens, 2012; Kalluri and Zeisberg, 2006).

The activation of angiogenesis results in the formation of abnormal, disorganized, and leaky blood vessels compared to the normal vasculature, which results in poor oxygen and nutrient supply. As a result, tumor cells become hypoxic due to the lack of oxygen, leading to increased cell survival, decreased apoptosis, and resistance to therapy (Trédan et al., 2007). Moreover, endothelial cells produce growth factors stimulating tumor growth and progression (Butler et al., 2010). Infiltrating immune cells in the tumor environment produce cytokines, chemokines and growth factors, including vascular endothelial growth factor (VEGF), which stimulate proliferation and promote angiogenesis (Balkwill and Mantovani, 2012; Hanahan and Coussens, 2012). Infiltrating immune cells also produce proteolytic enzymes degrading the ECM resulting in stimulation of tumor growth and invasion and bind to adhesion molecules to prevent tumor cell death by loss of tissue integrity (Chen et al., 2011). Tumor-associated macrophages can have both tumor promoting or suppressing functions and can produce cytokines suppressing immune responses against tumor cells (Qian and Pollard, 2010).

\section{The Notch signaling pathway}

Notch signaling is a highly conserved signaling pathway involved in proliferation and differentiation during embryonic development and in adult tissues (Siebel and Lendahl, 2017). During embryonic development Notch signaling plays an essential role in the development of somite-derived organs, including muscle cell differentiation (Buas et al., 2010; Hubaud and Pourquié, 2014; Kopan et al., 1994). Moreover, Notch signaling controls vasculogenesis and vascular branching during angiogenesis (Fischer et al., 2004; Krebs et al., 2000). Besides controlling vascular outgrowth, Notch signaling also regulates cardiac development, like coronary arterial differentiation (Farber et al., 2019), including the regulation of endocardial stem cells 
and proliferation of the myocardium (Grego-Bessa et al., 2007; Kokubo et al., 2005). In addition, Notch signaling regulates hematopoietic stem cell differentiation (Hadland et al., 2004; Han et al., 2002; Radtke et al., 1999) and maintains stem cells of the embryonic central nervous system during development (Gao et al., 2009; Imayoshi et al., 2010). Notch signaling also regulates epidermal proliferation and differentiation in the skin (Massi and Panelos, 2012), kidney development, hair cell differentiation in the cochlea (Brooker et al., 2006; Hartman et al., 2010; Kiernan et al., 2006) and balances the differentiation in the pancreas, in which loss of Notch signaling promotes endocrine differentiation (Apelqvist et al., 1999; Lammert et al., 2000).

During adult life Notch signaling also plays an essential role in tissue homeostasis. First of all, Notch signaling maintains stem cells in the intestinal crypts and promotes enterocyte differentiation by blocking secretory cell differentiation (Milano et al., 2004; van Es et al., 2005). Notch signaling does not only regulate cellfates decisions in the intestine, but also controls differentiation of B- and T-cells (Han et al., 2002; Pui et al., 1999), regulates cell fate decisions in skeletal muscle (Buas et al., 2010; Nofziger et al., 1999), lung (Mori et al., 2015; Rock et al., 2011), skin (Blanpain et al., 2006; Rishikaysh et al., 2014) and liver (Ortica et al., 2014), and maintains the endothelium of the vasculature (Bhattacharyya et al., 2014; Joutel et al., 2004; Sweeney et al., 2004).

The Notch signaling pathway mediates cell-to-cell communication and is activated by Notch ligand binding of a signal-sending cell to a Notch receptor on a signal-receiving cell. Subsequent proteolytic cleavages lead to the translocation of the cleaved receptor to the nucleus, where it activates its downstream targets. Mammals express four different Notch receptors, Notch1-4 (Figure 1). Notch receptors are single-pass transmembrane proteins composed of a series of specific protein domains. The extracellular region of the Notch receptor consists of a series of up to 36 EGF-like repeats and a negative regulatory region (NRR), which includes three Lin12/Notch repeats (LNRs) and a heterodimerization domain (HD). The intracellular region of the Notch receptor consists of a protein-binding RPBJassociated molecule (RAM) domain, seven ankyrin repeats (ANK), a transcriptional 

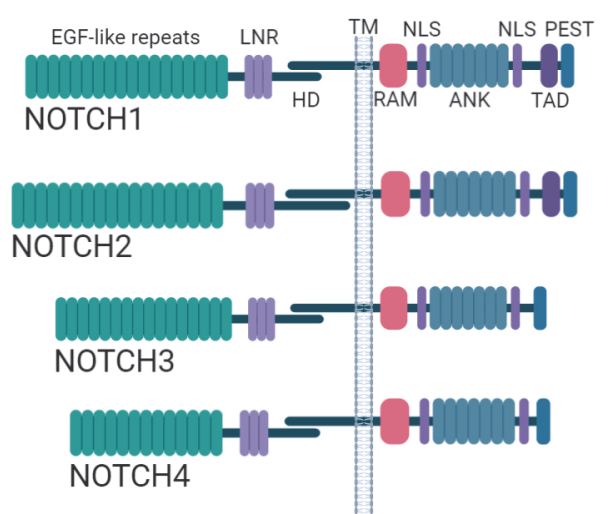

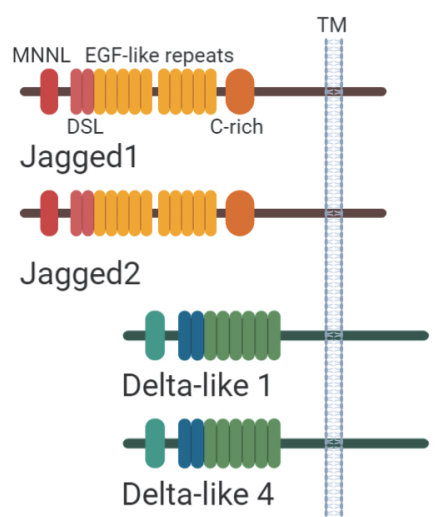

Delta-like 4

Figure 1. Mammalian Notch receptors and ligands. Mammals express four Notch receptors, including Notch1-4 and four Notch ligands, including Jagged1, Jagged2, Delta-like 1, and Delta-like 4. LNR: Lin12/Notch repeats, HD: heterodimerization domain, TM: transmembrane, RAM: protein-binding RPBJ-associated molecule, ANK: ankyrin repeats, TAD: transcriptional activation domain, PEST: C-terminal region rich in proline, glutamate, serine and threonine (adapted from Biorender).

activation domain (TAD), and a C-terminal region rich in proline, glutamate, serine and threonine (PEST domain). Notch receptors require ligands to activate Notch signaling. In mammals four ligands are expressed, which are also single transmembrane proteins. Delta-like 1 (DII1) and Delta-like 4 (DII4) are members of the Delta family of ligands and Jagged1 (Jag1) and Jagged2 (Jag2) are members of the Serrate family of ligands.

The Notch signaling pathway is initiated with the transcription of the Notch receptor in the nucleus (Figure 2). Next, the Notch receptor is transported from the ER to the Golgi apparatus, where it undergoes its first cleavage at the S1-site by furin-like protease. After this first proteolytic cleavage the heterodimeric $\mathrm{NOTCH}$ receptor (TMIC) is transported towards the plasma membrane, where it awaits ligand binding (Kopan and llagan, 2009). In the absence of ligand binding, the negative regulatory region (NRR) masks the S2-cleavage site, which results in auto-inhibition of the Notch receptor (Gordon et al., 2009). Upon ligand binding, the NRR unfolds and unmasks the S2-cleavage site of the Notch receptor (Mumm et al., 2000). The exposure of the S2-cleavage site recruits Adam10, which subsequently cleaves the 
Signal-sending cel

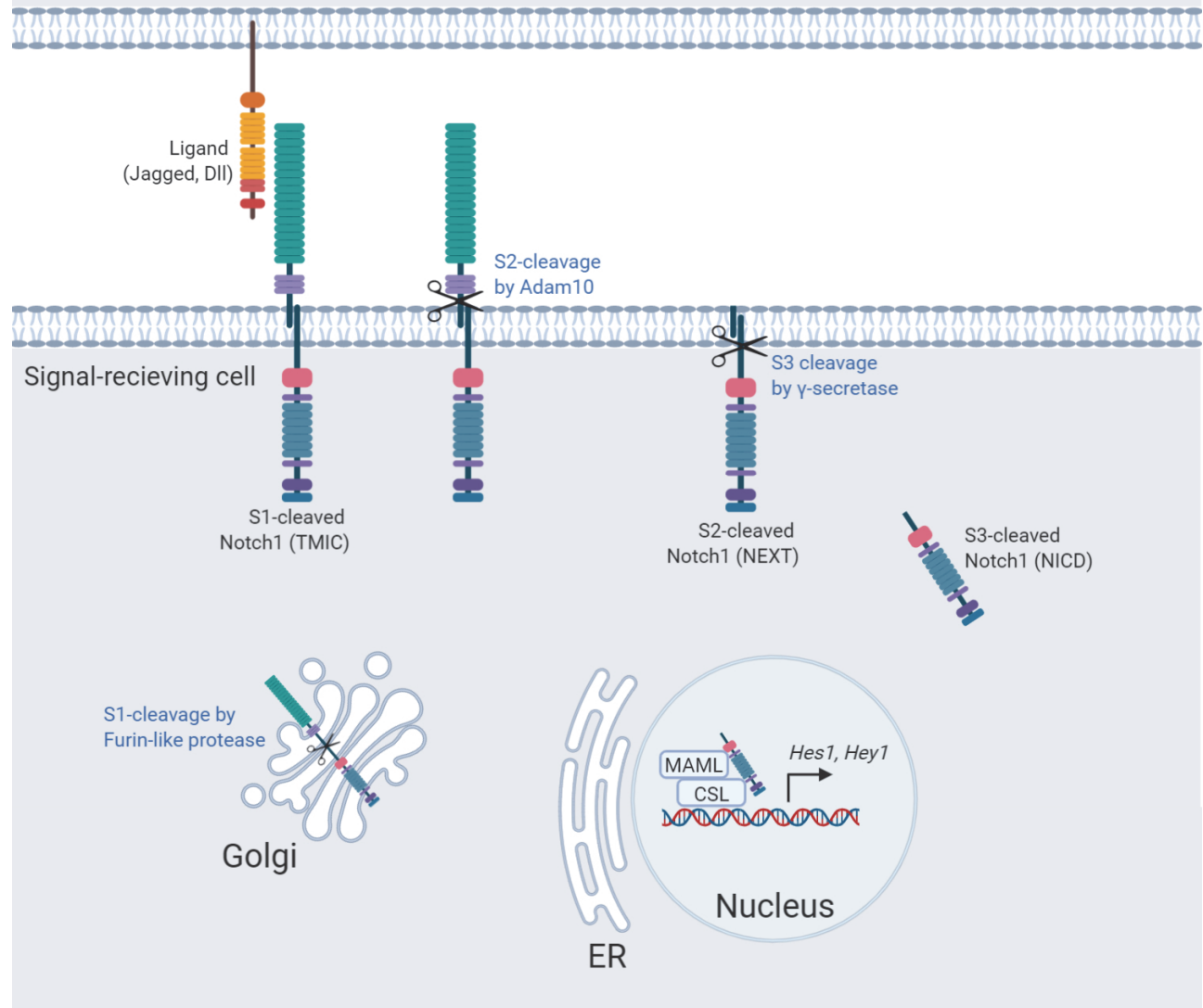

Figure 2. The Notch signaling pathway. Endogenous Notch signaling requires ligand binding, expressed by a signal-sending cell and three sequential cleavages to release the active form of Notch, which activates Notch downstream targets. TMIC: transmembrane intracellular fragment, NEXT: Notch extracellular truncation, NICD: Notch intracellular domain.

Notch receptor at Val1711, resulting in a membrane-tethered truncated Notch receptor (NEXT)(van Tetering et al., 2009). Finally, the Notch receptor is cleaved at Val1744 (S3-cleavage site) by the Y-secretase complex, which consists of four subunits including: presenilin 1 or 2, APH-1a or b, PEN-2 and nicastrin, and releases the Notch intracellular domain (NICD)(Kimberly et al., 2003). The NICD is transported towards the nucleus where it forms the Notch Transcription Complex 
(NTC) together with DNA-binding factor RBPJ (also known as CSL) and co-activators of the mastermind-like (MAML) family and binds to canonical DNA binding sites in the promoters and enhancers of Notch target genes (Kopan and Ilagan, 2009; Wu et al., 2000).

\section{Endocytic trafficking}

Endocytosis is the internalization of molecules by invagination of the plasma membrane and formation of intracellular vesicles, which is essential for the regulation of various pathways in the cell. Endocytosis is used to sort, process, recycle, store, and degrade internalized cargo to fine-tune the activation or silencing of signaling pathways. Endocytosis is initiated with the formation of an early endocytic vesicle from clathrin-coated pits, however, additional clathrin-independent internalization mechanisms exist (Mayor and Pagano, 2007). The majority of internalized cargo is recycled back to the plasma membrane, either direct via the small GTPase family member Rab4 or indirect via recycling endosomes regulated by Rab11 (Huotari and Helenius, 2011; Steinman et al., 1983)(Figure 3). A small proportion of endocytic vesicles fuse with each other and mature into late endosomes during which Rab5 is the main regulator. During endosome maturation Rab5 is exchanged for Rab7, which is the major regulator of intracellular trafficking in late endosomes and lysosomes. During maturation, early endosomes can form intraluminal vesicles, which require the recruitment of the components of the endosomal sorting complexes required for transport (ESCRT), leading to the formation of multivesicular bodies (MVBs) with double membranes (Huotari and Helenius, 2011). Sorting of internalized proteins is regulated by ubiquitination. ESCRT complexes recognize ubiquitinated cargo proteins and sort them into intraluminal vesicles in the MVBs. The formation of MVBs is important for the proper sorting of cargo for degradation in lysosomes and endosome maturation. Due to the formation of MVBs internalized cargo is retained from the cytosol and easily accessible for hydrolases once delivered to the lysosomes. During endocytic trafficking, the microenvironment of endosomes and lysosomes changes, due to ion in- and efflux (Scott and Gruenberg, 2011). Upon 


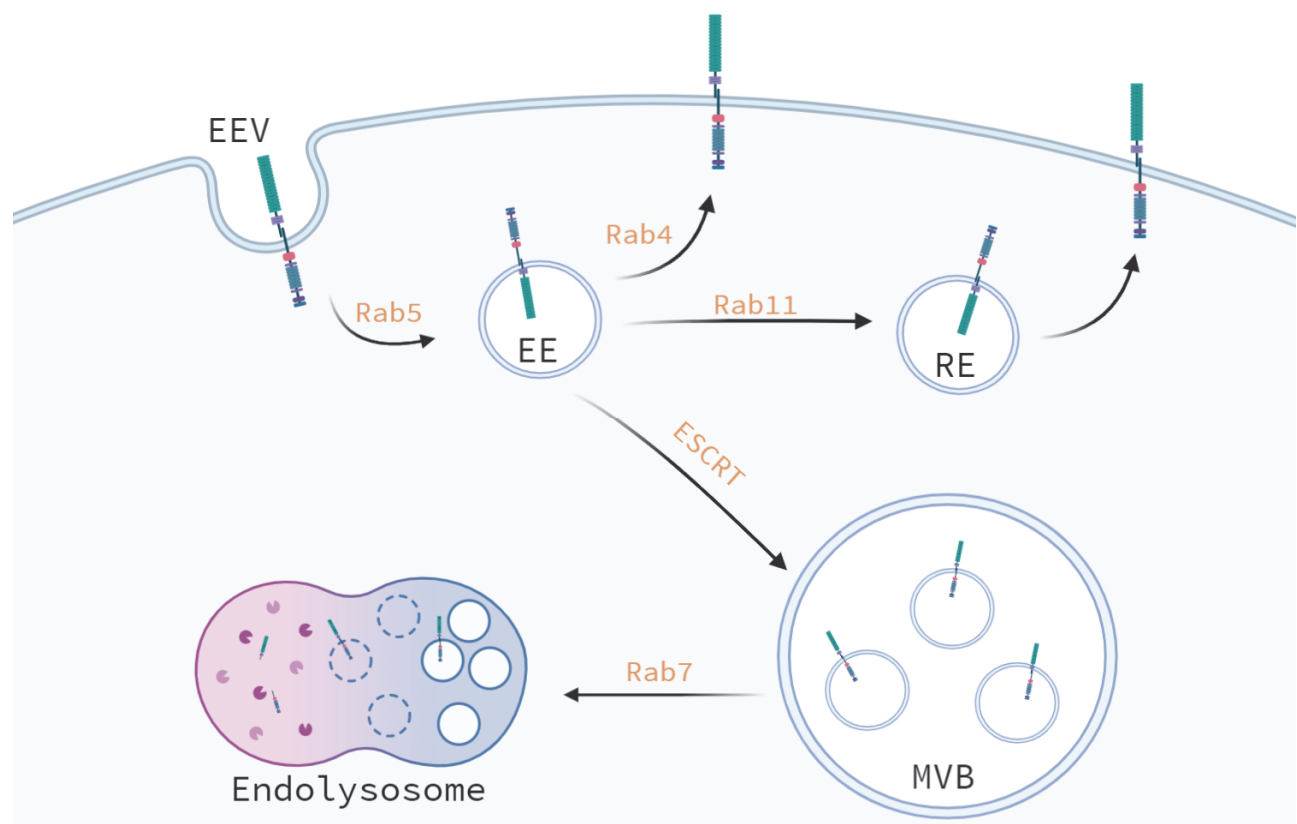

Figure 3. Endocytosis and intracellular trafficking. Membrane-tethered proteins are continuously internalized. While the majority of membrane-tethered proteins are directly transported back to the plasma membrane, the minority of membrane-tethered proteins are further transported towards the endocytic compartments and either recycled to the plasma membrane via recycling endosomes or degraded in the lysosomes. EEV: early endosomal vesicles, EE: early endosomes, RE: recycling endosomes, MVB: multivesicular bodies.

endosome maturation, endosomes become gradually more acidic due to increased $\mathrm{H}^{+}$-ion influx by the V-ATPase (Marshansky and Futai, 2008; Yan et al., 2009). These changes in $\mathrm{pH}$ affect protein-protein interactions, enzymatic activity and protein degradation during endocytic trafficking.

\section{Intracellular trafficking of the Notch signaling}

Although the Notch signaling pathway is already quite complex, due to the requirement of ligand-binding from an adjacent cell and subsequent proteolytic cleavages, an additional layer of complexity is added by the intracellular trafficking of Notch ligands and receptors. Intracellular trafficking has been shown to be essential for Notch signal activation in both signal-sending and signal-receiving cells 
as defects in endocytic trafficking lead to enhanced or reduced Notch activation dependent on the site of endocytic inhibition.

Currently, there are two models on the role of ligand endocytosis in the activation of Notch signaling: the "pulling force" and the "dissociation" model. The "pulling force" model states that endocytosis following the interaction between Notch ligand and receptor generates a mechanical force leading to conformational changes in the Notch receptor, revealing the S2-cleavage site for Adam cleavage and further Notch activation (Gordon et al., 2015). On the other hand, the "dissociation" model suggests that ligand endocytosis upon receptor binding induces mechanical forces, which physically dissociate the Notch receptor after which S2-cleavage and Notch receptor activation can proceed (Nichols et al., 2007).

Endocytic trafficking of Notch receptors can result in both activation or suppression of Notch signaling. Notch receptors, like other transmembrane bound proteins, are internalized for activation or degradation (Huotari and Helenius, 2011). Notch receptors are continuously internalized by clathrin- and dynamin dependent endocytosis (Chastagner et al., 2008; Vaccari et al., 2008). While the majority of receptors is transported back to the plasma membrane to await ligand binding, the minority of internalized Notch receptors travel further in the endocytic pathway, where they can either be activated in maturing endosomes or degraded in lysosomes. We review the endocytic trafficking of the Notch receptor in both Drosophila and mammals in more detail in chapter II.

\section{Chloroquine: disrupter of intracellular trafficking}

To study the role of intracellular trafficking in Notch activation and signaling we used chloroquine to disrupt intracellular trafficking and studied its effects on oncogenic Notch signaling in chapter III. The anti-malarial drug chloroquine was first produced in 1934 and was selected for its anti-malaria activity. Chloroquine acts on the early stages of malaria infection which enhances clearance of parasites, preventing further parasite production and development of clinical illness (Gregson and Plowe, 2005). In 1951 chloroquine became also a standard therapy for lupus erythematosus, due to its anti-inflammatory effects (Wolf et al., 2000), which resulted in further testing of 
chloroquine treatment in non-malarial diseases, showing effectiveness in a variety of dermatologic, immunologic, and rheumatologic disorders.

Chloroquine, which is a weak base, has been shown to affect several processes in the cell by elevating the $\mathrm{pH}$ in intracellular vesicles, including lysosomes (Ohkuma and Poole, 1978; Wolf et al., 2000). Various physiologic functions that depend on an acidic $\mathrm{pH}$ are affected by chloroquine, including immunomodulation by inhibition of antigen-presentation, cytokine production, surface-receptor recycling, and apoptosis of immune cells. Chloroquine has also been shown to reduce inflammation, increase nitric oxide production, block DNA, RNA and protein synthesis, and induce rapid degradation of ribosomes (Wolf et al., 2000).

An additional catabolic mechanism which is inhibited by chloroquine is autophagy, due to blockage of the fusion of auto-phagosomes with lysosomes. Autophagy allows the cell to recycle intracellular organelles and macromolecules to sustain growth and survival during stress (Rubinsztein et al., 2012; White, 2012). However, autophagy is also a survival mechanism for cancer cells. The anti-cancer efficacy of chloroquine has been shown in a broad range of malignancies, especially in combination with chemotherapy or radiotherapy in preclinical studies (Ding et al., 2011; Liang et al., 2014; Ratikan et al., 2013; Rouschop et al., 2010; Verbaanderd et al., 2017). As a result, clinical trials are ongoing to evaluate the safety and efficacy of hydroxychloroquine, a less toxic derivative of chloroquine (Browning, 2014), in a broad range of cancers, including brain, breast, bone, prostate, lung and colorectal cancer (Shi et al., 2017; Verbaanderd et al., 2017). However, chloroquine exhibits also autophagy independent effects on tumor progression, including tumor vessel normalization by the induction of Notch signaling in endothelial cells reducing tumor invasion and metastasis (Maes et al., 2014). Although chloroquine affects various physiological processes by elevating the cellular $\mathrm{pH}$, short-term administration rarely causes severe side effects. However, long term exposure shows more severe adverse effects in some cases, including: cardiomyopathy (Tönnesmann et al., 2013), retinal toxicity (Costedoat-Chalumeau et al., 2015), and induction of leukemia (Nagaratnam et al., 1978). Since chloroquine targets intracellular trafficking in vesicles and both Notch signaling and $\mathrm{pH}$ in vesicles is important, other processes 
that regulate vesicular $\mathrm{pH}$ may impact Notch signaling as well. One such process may be iron metabolism and transport, key to all living organisms.

\section{Iron homeostasis}

Iron is an essential nutrient for all organisms, facilitating proliferation and growth. Iron regulates oxygen transport by hemoglobin, oxygenation of muscles, oxidative phosphorylation, and DNA synthesis. Moreover, iron is an essential cofactor for many enzymes. Upon intestinal absorption, $\mathrm{Fe}^{3+}$ (non-heme) iron is reduced to $\mathrm{Fe}^{2+}$ by cytochrome $\mathrm{B}$, which is transported by the proton-coupled Divalent metal transporter 1 (Dmt1) across the apical membrane (Canonne-Hergaux et al., 1999; Fleming et al., 1997)(Figure 4). After intracellular trafficking, $\mathrm{Fe}^{2+}$ is exported by ferroportin across the basolateral membrane into the circulation accompanied by the re-oxidation of $\mathrm{Fe}^{2+}$ to $\mathrm{Fe}^{3+}$ to enable binding to transferrin (Abboud and Haile, 2000; Gkouvatsos et al., 2012). Ferroportin expression is regulated by hepcidin, a hormone, which binds to ferroportin and induces its internalization and degradation (Nemeth et al., 2004). Cellular iron uptake is mediated by the interaction of transferrin-bound iron to the transferrin receptor 1 (TfR1) and the subsequent internalization of this complex. The gradual acidification of the endosome triggers a conformational change in transferrin, resulting in the release of $\mathrm{Fe}^{3+}$ (Klausner et al., 1983). Following a second reduction to $\mathrm{Fe}^{2+}$, iron is transported by Dmt1 across the endosomal membrane to the cytosol and the Tf-TfR1 complex is recycled back to the plasma membrane, where Tf is released into the circulation. Iron in the cytosol is believed to enter the labile iron pool (LIP) where it provides iron for metabolic processes and proliferation. Cellular iron which is not immediately required for metabolic processes or enzymatic reactions, is sequestered in the cytosol within ferritin for storage (Gkouvatsos et al., 2012). Iron uptake, transport and storage are tightly regulated, which is essential as excess of iron is toxic due to its ability to catalyze the formation of free radicals via the Fenton reaction leading to cellular damage. Iron homeostasis is regulated by the iron response element (IRE)/iron regulatory protein (IRP) system. Most proteins involved in iron homeostasis are encoded by mRNAs containing one or more IREs in their untranslated regions 


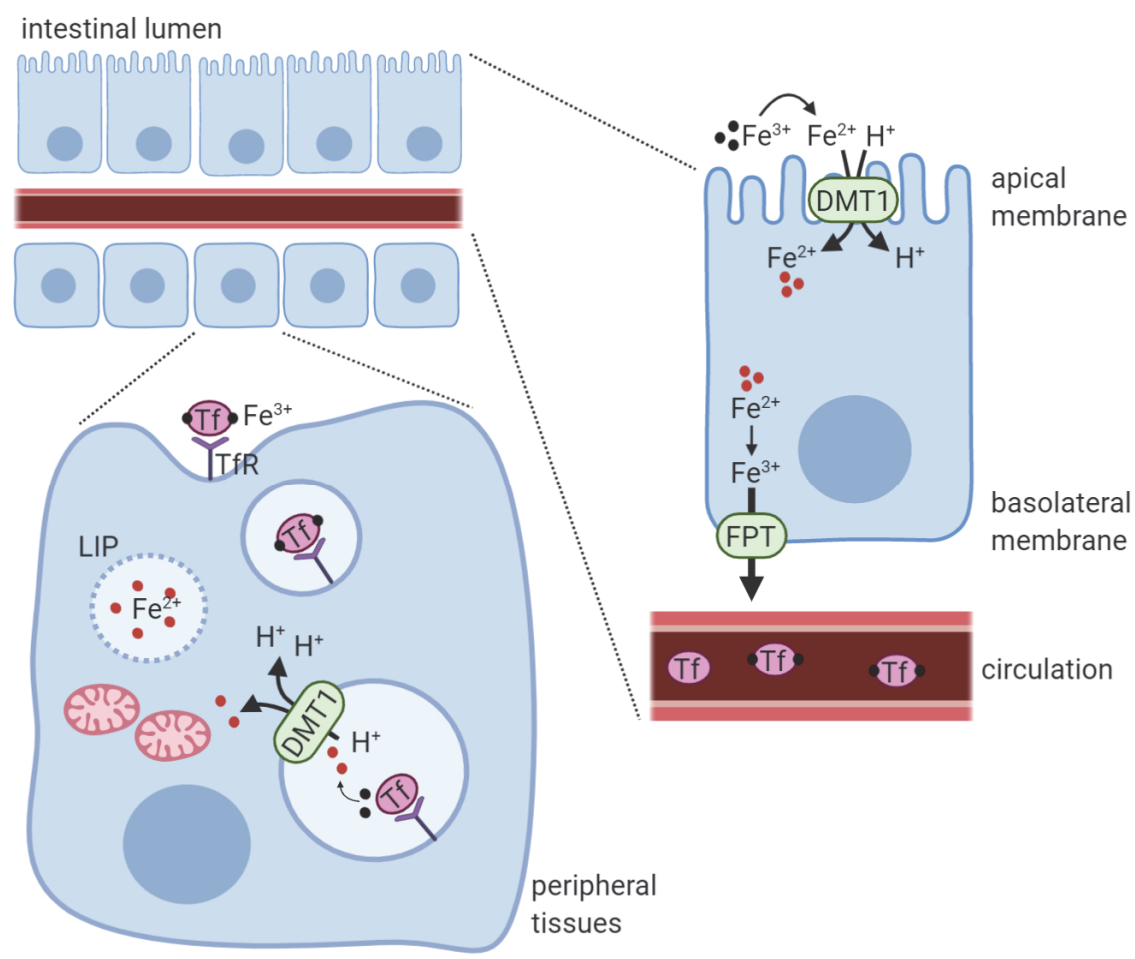

Figure 4. Iron homeostasis. Iron is absorbed in the intestine via transport across the apical membrane by Divalent metal transporter 1 (DMT1). Ferroportin (FPT) exports iron from the basolateral membrane of the enterocyte into the circulation. In the blood iron is bound to transferrin (Tf), which transports iron to adjacent cells via transferrin receptor (TfR)-mediated endocytosis. Iron is released into the cytosol by DMT1. LIP: labile iron pool.

(UTRs). These IREs are binding sites for iron regulatory proteins (IRP1 and IRP2), which sense iron levels in the labile iron pool and are activated in iron starved cells (Eisenstein, 2000; Rouault, 2006).

\section{Iron and cancer}

Although iron is essential for proper functioning of various processes in the cell, including proliferation and growth, iron can also have detrimental effects on cellular homeostasis due to its ability of forming free radicals, which may result in oxidative stress, inflammation, and DNA damage. Therefore, it is not surprising that iron 
homeostasis is often deregulated in malignant cancers (Kwok and Richardson, 2002; Steegmann-Olmedillas, 2011). Iron deficiency and iron deficiency-related anemia are reported in $40-70 \%$ of all cancer patients (Ludwig et al., 2015), which result from the excessive need of iron by tumor cells. Mouse models for mammary carcinoma show loss of iron storage in the liver and spleen due to accumulation of iron in tumor and stromal cells, especially in invasive, angiogenic, and necrotic regions (Freitas et al., 2007). Mechanistically, tumor cells do not only require iron to sustain their proliferative mode (Kwok and Richardson, 2002), but also use iron to remodel the extracellular matrix and increase their motility to promote invasion and metastasis (Fischer-Fodor et al., 2015). In contrast, an iron-deficient diet prior to breast cancer cell implanting in mice resulted in increased tumor volumes and metastasis due to increased Notch target gene expression leading to the activation of epithelial-tomesenchymal transition, which was reversed by iron therapy (Jian et al., 2013). However, only the expression of Notch2, Notch3, and Notch4 receptors was assessed and elevated. Changes in Notch1 receptor expression upon iron-deficient diet were not reported.

To sustain their increased iron demand, tumor cells adjust their intracellular iron metabolism by regulating the expression of iron regulatory genes to increase iron uptake and storage and decrease iron export. Increased expression of TfR1 has been reported in several cancers (Basuli et al., 2017; Högemann-Savellano et al., 2003). Elevated expression levels of the TfR 1 lead to increased uptake of transferrin bound iron (Habeshaw et al., 1983; Prutki et al., 2006; Shindelman et al., 1981). As a result, TfR1 expression is correlated with poor patient prognosis (Greene et al., 2017; Habashy et al., 2010). Increased iron levels have also been reported in colorectal cancers with concomitant overexpression of Dmt1 and TfR1 (Brookes et al., 2006). In addition, tumor cells also block iron efflux by ferroportin by up-regulation of hepcidin, which increases the degradation of ferroportin. Hepcidin expression has been reported to be elevated in a broad range of human malignancies, including prostate cancer (Tesfay et al., 2015), lung cancer (Chen et al., 2014), breast cancer (Ciniselli et al., 2015), multiple myeloma (Maes et al., 2010), and renal cell carcinoma (Kamai et al., 2009). The increased levels of hepcidin result in increased degradation 
of ferroportin, which is reported in breast (Pinnix et al., 2010), prostate (Tesfay et al., 2015), and ovarian cancer (Basuli et al., 2017), leading to decreased iron export in tumor cells compared to normal tissues, which correlates with poor patient outcome (Pinnix et al., 2010).

Since iron metabolism is deregulated in many cancers, several iron-targeted cancer therapies have been proposed. Iron chelators have been extensively studied as novel cancer therapeutics. In clinical trials iron chelators showed mild to moderate adverse effects, including gastrointestinal symptoms and fatigue (Cohen et al., 2000; Gattermann et al., 2010; Knox et al., 2007; Minden et al., 2014; Neufeld et al., 2012; Nutting et al., 2009; Yamasaki et al., 2011). Iron chelators showed promising antileukemic effects in advanced leukemia with $70 \%$ of patients showing a $50 \%$ reduction in white blood cell counts by triapine treatment (Giles et al., 2003). Additional iron chelators also showed improved patient outcome (List et al., 2012; Minden et al., 2014). However, solid tumors including metastatic renal cell carcinoma and head and neck tumors showed low anti-tumor efficacy in patients (Knox et al., 2007; Nutting et al., 2009). Although partial responses were reported in hepatocellular carcinoma (Yamasaki et al., 2011) and prostate cancer (Dreicer et al., 1997). Moreover, iron chelators have been combined with chemotherapy to increase therapeutic responses. In neuroblastoma and acute myeloid leukemia combining iron chelators with chemotherapy showed promising results (Donfrancesco et al., 1993; Zeidner et al., 2014), although this combination was ineffective in advanced non-small cell lung cancer (Traynor et al., 2010). Lastly, inhibition of hepcidin expression by neutralizing antibodies or inhibition of inflammatory pathways and ferroportin stabilizers to reactivate iron efflux in tumor cells are also being tested as a therapeutic approach (Gardenghi et al., 2010; Jayatilaka et al., 2017). Altogether, iron-targeting in cancer may be a promising therapeutic approach, however, antitumor efficacy may depend on the level of iron-addition of the tumor and proper patient selection might be required to increase the therapeutic efficacy. 


\section{Notch signaling affecting the hallmarks of cancer}

Notch signaling is a cell-cell communication pathway, which can promote or suppress cell proliferation, cell death, and induce specific cell fates or differentiation processes during development and self-renewing of adult tissues. As Notch signaling controls cell proliferation and differentiation, it is not surprising that deregulation of Notch signaling, which results in aberrant cell growth, is found in a broad range of malignancies. Notch signaling can affect all hallmarks of cancer depending on the tissue type, acting as a tumor oncogene of suppressor (Aster et al., 2017). First of all, Notch signaling sustains proliferation of tumor cells by activating c-Myc, which stimulates cell cycle progression and proliferation and inhibits cell death (Palomero et al., 2006). Moreover, Notch signaling activates other pro-growth signaling pathways, including PI3K-Akt signaling by repression of Pten (Palomero et al., 2007). Akt signaling also activates MDM2, which results in TP53 degradation and prevents the activation of the DNA damage response and a cell cycle arrest upon DNA damage further sustaining tumor growth and enhancing genomic instability (Gottlieb et al., 2002). In addition to sustaining tumor growth, Akt signaling also promotes tumor cell survival by increasing the expression of NF-K $\beta$ and inhibition of cell death (Manning and Cantley, 2007). Moreover, stromal cells expressing Notch ligands in the microenvironment may support proliferation of tumor cells in the metastatic niche by activation of Notch signaling.

In addition to sustaining proliferation, survival, and inhibition of tumor cell death, Notch signaling has also been reported to promote epithelial-to-mesenchymal transition, by inducing the expression of TGF- $\beta$ and Snail (Sahlgren et al., 2008; Timmerman et al., 2004), promoting tumor invasion and metastasis. Moreover, Notch signaling has an essential role in angiogenesis and vessel maintenance during development (Gridley, 2007) and suppression of Notch signaling by targeting DII4 has been shown to result in excessive, non-functional tumor angiogenesis, reducing tumor growth (Kuhnert et al., 2011). Furthermore, accumulating evidence suggests that Notch signaling maintains cancer cells in the stem cell niche in a broad range of malignancies, including glioblastoma, ovarian cancer, and breast cancer. Notch inhibition in these malignancies results in decreased expression of stem cell markers, 
reduces tumor growth, and induces treatment sensitivity (D'Angelo et al., 2015; Fan et al., 2010; McAuliffe et al., 2012; Yahyanejad et al., 2016; Zhu et al., 2011).

\section{Notch signaling in human malignancies}

Aberrant Notch signaling has been found in a broad range of human malignancies. First of all, T-cell acute lymphoblastic leukemia (T-ALL) is well-known for harboring mutations in NOTCH1 leading to ligand-independent NOTCH1 signaling (Weng et al., 2004). Approximately $60 \%$ of all human T-ALL have activating mutations in the heterodimerization (HD) and PEST domain of NOTCH1. Due to the mutations in the HD domain, the Notch receptor undergoes conformational changes, which unmask the S2-cleavage site making it accessible for cleavage in the absence of ligand binding. HD domain mutations are often combined with PEST domain mutations in the NOTCH receptor, which prevent the rapid degradation of the active NICD, prolonging the constitutive ligand-independent Notch activity. Despite NOTCH1 mutations in T-ALL, inactivating mutations or deletions in the F-box and WD repeat domain-containing ( $F B W 7$ ) gene have also been reported in a selected group of TALL patients. The FBW7 gene encodes for a ubiquitin ligase, which regulates the degradation of NICD (Malecki et al., 2006; O'Neil et al., 2007; Thompson et al., 2007). Therefore, the loss of FBW7 results in the expression of a constitutively active NICD independently of $\mathrm{Y}$-secretase activity in T-ALL. Aberrant Notch signaling has also been reported in other types of leukemia, where Notch can act as an oncogene or tumor suppressor depending on the type of malignancy (Aster et al., 2017).

Secondly, deregulation of NOTCH1 and NOTCH2 due to genomic rearrangements has also been reported in breast cancer, from which the majority was derived from triple-negative breast cancers (Robinson et al., 2011). These rearrangements in NOTCH1 result in a truncated membrane-tethered NOTCH1 receptor, which remains dependent on Y-secretase activity, however, acts independently of ligand binding and S2-cleavage. In NOTCH2 the rearrangements result in a truncated cytoplasmic NICD, which acts independently of $\mathrm{y}$-secretase cleavage. Besides, approximately $10 \%$ of all non-small cell lung cancers (NSCLC) 
also harbor gain-of-function mutations in NOTCH1, which also localize to the HD and PEST domain (Westhoff et al., 2009).

Lastly, Notch signaling is deregulated in a broad range of human malignancies, although mutations or rearrangements in $\mathrm{NOTCH}$ are only found in $\mathrm{T}$ ALL and a selective group of breast and lung cancer patients. In the majority of cancers, $\mathrm{NOTCH}$ deregulation is not due to genetic alterations in $\mathrm{NOTCH}$ itself, but results from mutations or deregulations in the negative regulators of NOTCH signaling. For example, in approximately $50 \%$ of all human breast cancers and in $30 \%$ of all human NSCLC NUMB signaling is lost (Pece et al., 2004; Westhoff et al., 2009). Loss of NUMB, a negative regulator of Notch signaling and tumor suppressor, results in NOTCH signaling activation.

\section{Therapeutic targeting Notch signaling in cancer}

As a consequence of the high frequency of aberrant NOTCH signaling in human malignancies, $Y$-secretase inhibitors (GSI) have been used as small molecule inhibitors to target the NOTCH1 signaling pathway. Unfortunately, GSI showed limited anti-leukemic activity as a result of dose-limiting toxicities in normal tissues as shown in animal models (Milano et al., 2004; Wong et al., 2004). One of the main dose-limiting toxicities induced by GSI is gastrointestinal toxicity, which results from severe goblet cell metaplasia in the intestine leading to diarrhea, nausea, mucositis, and dehydration. This excessive secretory differentiation results from the simultaneous inhibition of Notch1 and Notch2, which function redundantly in regulating the proliferation and differentiation in the intestinal crypt (Milano et al., 2004; Riccio et al., 2008; van Es et al., 2005; Wong et al., 2004). In addition to intestinal toxicity, adverse effects of the inhibition of Notch signaling have also been reported in the skin, causing moderate dermatitis, cell hyperplasia, and inclusion cysts in preclinical studies, due to Notch-mediated keratinocyte differentiation by Notch signaling (Rangarajan et al., 2001). Although Notch inhibition showed adverse side effects on the immune system in preclinical trials (Wong et al., 2004), no severe toxicities are reported in patients. Lastly, inhibition of Notch signaling can also lead to vascular abnormalities and induce vascular tumors (Yan et al., 2010). Indeed, in 
patients, NOTCH inhibition also showed vascular toxicities accounting for cardiac arrest, tachycardia, ventricular dysfunction, and congestive heart failure (Chiorean et al., 2015; Smith et al., 2014).

A lack of predictive biomarkers for patient selection, a shortage of robust pharmacological markers to measure on target activity (Krop et al., 2012), and a lack of specificity of current inhibitors targeting multiple Notch family members lead to low anti-tumor activity and toxicity in normal tissues. Therefore, these current challenges need to be solved to be able to use oncogenic NOTCH signaling as a therapeutic target and improve patient outcome. Importantly, chronic uninterrupted GSI treatment results in high toxicity, while intermittent scheduling remarkably reduces dose-limiting toxicities and shows strong modulation of the $\mathrm{NOTCH}$ signaling pathway resulting in anti-tumor activity in phase I clinical trials (Krop et al., 2012; Tolcher et al., 2012).

Additional Notch targeting strategies have been developed, including the use of monoclonal antibodies against Notch ligands and receptors. Monoclonal antibodies against DIl4, which regulates tumor initiation and angiogenesis (Fischer et al., 2011; Noguera-Troise et al., 2006; Ridgway et al., 2006), were well tolerated and showed anti-tumor activity in phase I clinical trials (Chiorean et al., 2015; Smith et al., 2014). Besides, the development of a Notch1 receptor specific monoclonal antibody showed promising preclinical results, including inhibition of tumor growth, deregulation of angiogenesis, and reduced goblet cell metaplasia compared to panNotch inhibition (Wu et al., 2010). Additional monoclonal antibodies that specifically target activated Notch receptors have also shown promising preclinical results, however, phase II clinical studies are awaited (Tiyanont et al., 2013). Tarextumab, a monoclonal antibody targeting both Notch2 and Notch3, showed inhibition of NOTCH signaling in a phase I trial and was well tolerated using intermittent scheduling (Smith et al., 2019), although combined with chemotherapy failed to improve patient outcome in pancreatic adenocarcinoma (Hu et al., 2019).

Altogether, over the last two decades targeting of NOTCH signaling as a therapeutic approach in human malignancies has evolved from a bulk inhibition with 
severe side effects and dose-limiting toxicity to more specific and better tolerable strategies.

\section{Outline of this thesis}

Although extensive progress has been made over the last two decades in the therapeutic targeting of $\mathrm{NOTCH}$ signaling, it still remains essential to obtain a better understanding in the molecular mechanisms of $\mathrm{NOTCH}$ signaling and its key regulators. Therefore, the aim of this thesis was to extend our knowledge on NOTCH signaling, especially in the differences between $\mathrm{NOTCH}$ signaling in cancer and in normal tissues. These differences could be exploited allowing to specifically target oncogenic NOTCH signaling without affecting physiologic NOTCH signaling in adult tissues, leading to enhanced tumor control, reduced toxicity, and improved patient outcome. In this thesis we used two different approaches to address this aim. First, we used chloroquine, an anti-malarial drug which is cheap and easy to produce, as a repurposed drug in the treatment of NOTCH-driven T-ALL in combination with GSI. Secondly, we performed an shRNA silencing screen to discover novel regulators of Notch signaling and potential targets to broaden our therapeutic landscape for Notch inhibition.

In chapter II we review the current knowledge on intracellular Notch receptor trafficking and activation in both Drosophila and mammals. We focus on ligandindependent Notch signaling in human malignancies, elaborate on the current (proposed) mechanisms of ligand-independent Notch signaling, and discuss the essential role of intracellular trafficking. Finally, we discuss the essence of specific targeting of ligand-independent Notch signaling in cancer and its current challenges.

In chapter III we show that the anti-malarial drug chloroquine (CQ), an inhibitor of endosomal and lysosomal function, sensitizes oncogenic NOTCH1 driven human T-ALL to $Y$-secretase inhibition (GSI). Chloroquine decreases human T-ALL cell viability and proliferation, which is even further enhanced when combined with GSI. Mechanistically, chloroquine impairs the redox balance, inducing DNA damage and activating the DNA damage response leading to a block in cell cycle progression. Besides, we show that chloroquine interferes with ligand-independent NOTCH 
signaling by deregulating $\mathrm{NOTCH}$ receptor trafficking and processing. We show that chloroquine treatment results in enhanced protein levels of full length and cleaved $\mathrm{NOTCH}$ receptors and leads to the accumulation of the $\mathrm{NOTCH}$ receptors in intracellular vesicles, especially when combined with GSI. These effects of chloroquine were not observed in GSI-resistant T-ALL cells.

In chapter IV we performed a shRNA screen in Notch Adam proteasedeficient mouse embryonic fibroblasts to identify novel rate-limiting steps in the Notch1 signaling cascade. We identified Divalent metal transporter 1 (Dmt1) as a novel regulator of Notch-mediated cell fate decisions in muscle, neural, and colorectal cells. We report that the four isoforms of Dmt1 differentially regulate Notch signaling processing and activation. Inhibition of Dmt1b-ire isoforms results in a lossof-function of Notch signaling, while knockdown of Dmt1b+ire isoforms results in an activation of Notch signaling. Moreover, we show that a complete loss of Dmt1 isoforms results in attenuated ligand-induced Notch signaling, which may result from disturbed intracellular trafficking.

To conclude, we summarize our findings of the previous chapters in chapter $\mathbf{V}$ and outline the remaining challenges to be addressed in future research. 


\section{References}

1. Abboud, S., and Haile, D. J. (2000). A novel mammalian iron-regulated protein involved in intracellular iron metabolism. Journal of Biological Chemistry 275, 19906-19912.

2. Apelqvist, A., Li, H., Sommer, L., Beatus, P., Anderson, D. J., Honjo, T., Hrabe de Angelis, M., Lendahl, U., and Edlund, H. (1999). Notch signalling controls pancreatic cell differentiation. Nature 400, 877-881.

3. Aster, J. C., Pear, W. S., and Blacklow, S. C. (2017). The varied roles of Notch in cancer. Annual Review of Pathology: Mechanisms of Disease 12, 245-275.

4. Balkwill, F. R., and Mantovani, A. (2012). Cancer-related inflammation: common themes and therapeutic opportunities. Paper presented at: Seminars in cancer biology (Elsevier).

5. Basuli, D., Tesfay, L., Deng, Z., Paul, B., Yamamoto, Y., Ning, G., Xian, W., McKeon, F., Lynch, M., and Crum, C. P. (2017). Iron addiction: a novel therapeutic target in ovarian cancer. Oncogene 36, 4089-4099.

6. Bhattacharyya, A., Lin, S., Sandig, M., and Mequanint, K. (2014). Regulation of vascular smooth muscle cell phenotype in three-dimensional coculture system by Jagged1selective Notch3 signaling. Tissue Eng Part A 20, 1175-1187.

7. Blanpain, C., Lowry, W. E., Pasolli, H. A., and Fuchs, E. (2006). Canonical notch signaling functions as a commitment switch in the epidermal lineage. Genes Dev 20, 3022-3035.

8. Brooker, R., Hozumi, K., and Lewis, J. (2006). Notch ligands with contrasting functions: Jagged1 and Delta1 in the mouse inner ear. Development 133, 1277-1286.

9. Brookes, M. J., Hughes, S., Turner, F. E., Reynolds, G., Sharma, N., Ismail, T., Berx, G., McKie, A. T., Hotchin, N., and Anderson, G. J. (2006). Modulation of iron transport proteins in human colorectal carcinogenesis. Gut 55, 1449-1460.

10. Browning, D. J. (2014). Pharmacology of chloroquine and hydroxychloroquine. In Hydroxychloroquine and chloroquine retinopathy, (Springer), pp. 35-63.

11. Buas, M. F., Kabak, S., and Kadesch, T. (2010). The Notch effector Hey1 associates with myogenic target genes to repress myogenesis. J Biol Chem 285, 1249-1258.

12. Butler, J. M., Kobayashi, H., and Rafii, S. (2010). Instructive role of the vascular niche in promoting tumour growth and tissue repair by angiocrine factors. Nature Reviews Cancer 10, 138-146.

13. Canonne-Hergaux, F., Gruenheid, S., Ponka, P., and Gros, P. (1999). Cellular and subcellular localization of the Nramp2 iron transporter in the intestinal brush border and 
regulation by dietary iron. Blood, The Journal of the American Society of Hematology 93, 4406-4417.

14. Chastagner, P., Israel, A., and Brou, C. (2008). AIP4/Itch regulates Notch receptor degradation in the absence of ligand. PloS one 3.

15. Chen, Q., Wang, L., Ma, Y., Wu, X., Jin, L., and Yu, F. (2014). Increased hepcidin expression in non-small cell lung cancer tissue and serum is associated with clinical stage. Thorac Cancer 5, 14-24.

16. Chen, Q., Zhang, X. H.-F., and Massagué, J. (2011). Macrophage binding to receptor VCAM-1 transmits survival signals in breast cancer cells that invade the lungs. Cancer cell 20, 538-549.

17. Chiorean, E. G., LoRusso, P., Strother, R. M., Diamond, J. R., Younger, A., Messersmith, W. A., Adriaens, L., Liu, L., Kao, R. J., DiCioccio, A. T., et al. (2015). A Phase I First-in-Human Study of Enoticumab (REGN421), a Fully Human Delta-like Ligand 4 (DII4) Monoclonal Antibody in Patients with Advanced Solid Tumors. Clin Cancer Res 21, 2695-2703.

18. Ciniselli, C. M., De Bortoli, M., Taverna, E., Varinelli, L., Pizzamiglio, S., Veneroni, S., Bonini, C., Orlandi, R., Verderio, P., and Bongarzone, I. (2015). Plasma hepcidin in earlystage breast cancer patients: no relationship with interleukin-6, erythropoietin and erythroferrone. Expert Rev Proteomics 12, 695-701.

19. Cohen, A. R., Galanello, R., Piga, A., Dipalma, A., Vullo, C., and Tricta, F. (2000). Safety profile of the oral iron chelator deferiprone: a multicentre study. British journal of haematology 108, 305-312.

20. Costedoat-Chalumeau, N., Dunogué, B., Leroux, G., Morel, N., Jallouli, M., Le Guern, V., Piette, J. C., Brézin, A. P., Melles, R. B., and Marmor, M. F. (2015). A Critical Review of the Effects of Hydroxychloroquine and Chloroquine on the Eye. Clin Rev Allergy Immunol 49, 317-326.

21. D'Angelo, R. C., Ouzounova, M., Davis, A., Choi, D., Tchuenkam, S. M., Kim, G., Luther, T., Quraishi, A. A., Senbabaoglu, Y., and Conley, S. J. (2015). Notch reporter activity in breast cancer cell lines identifies a subset of cells with stem cell activity. Molecular cancer therapeutics $14,779-787$.

22. Ding, Z.-B., Hui, B., Shi, Y.-H., Zhou, J., Peng, Y.-F., Gu, C.-Y., Yang, H., Shi, G.-M., Ke, A.-W., and Wang, X.-Y. (2011). Autophagy activation in hepatocellular carcinoma contributes to the tolerance of oxaliplatin via reactive oxygen species modulation. Clinical Cancer Research 17, 6229-6238. 
23. Donfrancesco, A., Deb, G., Angioni, A., Maurizio, C., Cozza, R., Jenkner, A., Landolfo, A., Boglino, C., and Helson, L. (1993). D-CECaT: a breakthrough for patients with neuroblastoma. Anti-cancer drugs 4, 317-321.

24. Dreicer, R., Kemp, J. D., Stegink, L. D., Cardillo, T., Davis, C. S., Forest, P. K., and See, W. A. (1997). A phase II trial of deferoxamine in patients with hormone-refractory metastatic prostate cancer. Cancer investigation 15, 311-317.

25. Eisenstein, R. S. (2000). Iron regulatory proteins and the molecular control of mammalian iron metabolism. Annual review of nutrition 20,627-662.

26. Fan, X., Khaki, L., Zhu, T. S., Soules, M. E., Talsma, C. E., Gul, N., Koh, C., Zhang, J., Li, Y. M., and Maciaczyk, J. (2010). NOTCH pathway blockade depletes CD133-positive glioblastoma cells and inhibits growth of tumor neurospheres and xenografts. Stem cells 28, 5-16.

27. Farber, G., Parks, M. M., Lustgarten Guahmich, N., Zhang, Y., Monette, S., Blanchard, S. C., Di Lorenzo, A., and Blobel, C. P. (2019). ADAM10 controls the differentiation of the coronary arterial endothelium. Angiogenesis 22, 237-250.

28. Fischer-Fodor, E., Miklasova, N., Berindan-Neagoe, I., and Saha, B. (2015). Iron, inflammation and invasion of cancer cells. Clujul Med 88, 272-277.

29. Fischer, A., Schumacher, N., Maier, M., Sendtner, M., and Gessler, M. (2004). The Notch target genes Hey1 and Hey2 are required for embryonic vascular development. Genes Dev 18, 901-911.

30. Fischer, M., Yen, W. C., Kapoun, A. M., Wang, M., O'Young, G., Lewicki, J., Gurney, A., and Hoey, T. (2011). Anti-DLL4 inhibits growth and reduces tumor-initiating cell frequency in colorectal tumors with oncogenic KRAS mutations. Cancer research 71, 1520-1525.

31. Fleming, M. D., Trenor, C. C., Su, M. A., Foernzler, D., Beier, D. R., Dietrich, W. F., and Andrews, N. C. (1997). Microcytic anaemia mice have a mutation in Nramp2, a candidate iron transporter gene. Nat Genet 16, 383-386.

32. Freitas, I., Boncompagni, E., Vaccarone, R., Fenoglio, C., Barni, S., and Baronzio, G. F. (2007). Iron accumulation in mammary tumor suggests a tug of war between tumor and host for the microelement. Anticancer Res 27, 3059-3065.

33. Gao, F., Zhang, Q., Zheng, M. H., Liu, H. L., Hu, Y. Y., Zhang, P., Zhang, Z. P., Qin, H. Y., Feng, L., Wang, L., et al. (2009). Transcription factor RBP-J-mediated signaling represses the differentiation of neural stem cells into intermediate neural progenitors. Mol Cell Neurosci 40, 442-450. 
34. Gardenghi, S., Ramos, P., Marongiu, M. F., Melchiori, L., Breda, L., Guy, E., Muirhead, K., Rao, N., Roy, C. N., Andrews, N. C., et al. (2010). Hepcidin as a therapeutic tool to limit iron overload and improve anemia in $\beta$-thalassemic mice. J Clin Invest 120, 44664477.

35. Gattermann, N., Finelli, C., Della Porta, M., Fenaux, P., Ganser, A., Guerci-Bresler, A., Schmid, M., Taylor, K., Vassilieff, D., and Habr, D. (2010). Deferasirox in iron-overloaded patients with transfusion-dependent myelodysplastic syndromes: results from the large 1-year EPIC study. Leukemia research 34, 1143-1150.

36. Giles, F. J., Fracasso, P. M., Kantarjian, H. M., Cortes, J. E., Brown, R. A., Verstovsek, S., Alvarado, Y., Thomas, D. A., Faderl, S., and Garcia-Manero, G. (2003). Phase I and pharmacodynamic study of Triapine $\AA$, a novel ribonucleotide reductase inhibitor, in patients with advanced leukemia. Leukemia research 27, 1077-1083.

37. Gkouvatsos, K., Papanikolaou, G., and Pantopoulos, K. (2012). Regulation of iron transport and the role of transferrin. Biochimica et Biophysica Acta (BBA)-General Subjects $1820,188-202$.

38. Gordon, W. R., Roy, M., Vardar-Ulu, D., Garfinkel, M., Mansour, M. R., Aster, J. C., and Blacklow, S. C. (2009). Structure of the Notch1-negative regulatory region: implications for normal activation and pathogenic signaling in T-ALL. Blood, The Journal of the American Society of Hematology 113, 4381-4390.

39. Gordon, W. R., Zimmerman, B., He, L., Miles, L. J., Huang, J., Tiyanont, K., McArthur, D. G., Aster, J. C., Perrimon, N., and Loparo, J. J. (2015). Mechanical allostery: evidence for a force requirement in the proteolytic activation of Notch. Developmental cell 33, 729736.

40. Gottlieb, T. M., Leal, J. F. M., Seger, R., Taya, Y., and Oren, M. (2002). Cross-talk between Akt, p53 and Mdm2: possible implications for the regulation of apoptosis. Oncogene 21, 1299-1303.

41. Greene, C. J., Attwood, K., Sharma, N. J., Gross, K. W., Smith, G. J., Xu, B., and Kauffman, E. C. (2017). Transferrin receptor 1 upregulation in primary tumor and downregulation in benign kidney is associated with progression and mortality in renal cell carcinoma patients. Oncotarget 8, 107052.

42. Grego-Bessa, J., Luna-Zurita, L., del Monte, G., Bolós, V., Melgar, P., Arandilla, A., Garratt, A. N., Zang, H., Mukouyama, Y. S., Chen, H., et al. (2007). Notch signaling is essential for ventricular chamber development. Dev Cell 12, 415-429.

43. Gregson, A., and Plowe, C. V. (2005). Mechanisms of resistance of malaria parasites to antifolates. Pharmacological reviews 57, 117-145. 
44. Gridley, T. (2007). Notch signaling in vascular development and physiology. Development 134, 2709-2718.

45. Habashy, H. O., Powe, D. G., Staka, C. M., Rakha, E. A., Ball, G., Green, A. R., Aleskandarany, M., Paish, E. C., Macmillan, R. D., and Nicholson, R. I. (2010). Transferrin receptor (CD71) is a marker of poor prognosis in breast cancer and can predict response to tamoxifen. Breast cancer research and treatment 119, 283.

46. Habeshaw, J., Lister, T., Stansfeld, A., and Greaves, M. (1983). Correlation of transferrin receptor expression with histological class and outcome in non-Hodgkin lymphoma. The Lancet 321, 498-501.

47. Hadland, B. K., Huppert, S. S., Kanungo, J., Xue, Y., Jiang, R., Gridley, T., Conlon, R. A., Cheng, A. M., Kopan, R., and Longmore, G. D. (2004). A requirement for Notch1 distinguishes 2 phases of definitive hematopoiesis during development. Blood 104, 3097-3105.

48. Han, H., Tanigaki, K., Yamamoto, N., Kuroda, K., Yoshimoto, M., Nakahata, T., Ikuta, K., and Honjo, T. (2002). Inducible gene knockout of transcription factor recombination signal binding protein-J reveals its essential role in T versus $B$ lineage decision. Int Immunol 14, 637-645.

49. Hanahan, D., and Coussens, L. M. (2012). Accessories to the crime: functions of cells recruited to the tumor microenvironment. Cancer cell 21, 309-322.

50. Hanahan, D., and Weinberg, R. A. (2000). The hallmarks of cancer. cell 100, 57-70.

51. Hanahan, D., and Weinberg, R. A. (2011). Hallmarks of cancer: the next generation. cell 144, 646-674.

52. Hartman, B. H., Reh, T. A., and Bermingham-McDonogh, O. (2010). Notch signaling specifies prosensory domains via lateral induction in the developing mammalian inner ear. Proc Natl Acad Sci U S A 107, 15792-15797.

53. Högemann-Savellano, D., Bos, E., Blondet, C., Sato, F., Abe, T., Josephson, L., Weissleder, R., Gaudet, J., Sgroi, D., and Peters, P. J. (2003). The transferrin receptor: a potential molecular imaging marker for human cancer. Neoplasia (New York, NY) 5 , 495.

54. Hu, Z. I., Bendell, J. C., Bullock, A., LoConte, N. K., Hatoum, H., Ritch, P., Hool, H., Leach, J. W., Sanchez, J., Sohal, D. P. S., et al. (2019). A randomized phase II trial of nab-paclitaxel and gemcitabine with tarextumab or placebo in patients with untreated metastatic pancreatic cancer. Cancer Med 8, 5148-5157.

55. Hubaud, A., and Pourquié, O. (2014). Signalling dynamics in vertebrate segmentation. Nat Rev Mol Cell Biol 15, 709-721. 
56. Huotari, J., and Helenius, A. (2011). Endosome maturation. The EMBO journal 30, 34813500 .

57. Imayoshi, I., Sakamoto, M., Yamaguchi, M., Mori, K., and Kageyama, R. (2010). Essential roles of Notch signaling in maintenance of neural stem cells in developing and adult brains. J Neurosci 30, 3489-3498.

58. Jayatilaka, H., Tyle, P., Chen, J. J., Kwak, M., Ju, J., Kim, H. J., Lee, J. S. H., Wu, P.H., Gilkes, D. M., Fan, R., and Wirtz, D. (2017). Synergistic IL-6 and IL-8 paracrine signalling pathway infers a strategy to inhibit tumour cell migration. Nature Communications 8, 15584.

59. Jian, J., Yang, Q., Shao, Y., Axelrod, D., Smith, J., Singh, B., Krauter, S., Chiriboga, L., Yang, Z., Li, J., and Huang, X. (2013). A link between premenopausal iron deficiency and breast cancer malignancy. BMC Cancer 13, 307.

60. Joutel, A., Monet, M., Domenga, V., Riant, F., and Tournier-Lasserve, E. (2004). Pathogenic mutations associated with cerebral autosomal dominant arteriopathy with subcortical infarcts and leukoencephalopathy differently affect Jagged1 binding and Notch3 activity via the RBP/JK signaling Pathway. Am J Hum Genet 74, 338-347.

61. Kalluri, R., and Zeisberg, M. (2006). Fibroblasts in cancer. Nature Reviews Cancer 6, 392-401.

62. Kamai, T., Tomosugi, N., Abe, H., Arai, K., and Yoshida, K. (2009). Increased serum hepcidin-25 level and increased tumor expression of hepcidin mRNA are associated with metastasis of renal cell carcinoma. BMC Cancer 9, 270.

63. Kiernan, A. E., Xu, J., and Gridley, T. (2006). The Notch ligand JAG1 is required for sensory progenitor development in the mammalian inner ear. PLoS Genet 2, e4.

64. Kimberly, W. T., LaVoie, M. J., Ostaszewski, B. L., Ye, W., Wolfe, M. S., and Selkoe, D. J. (2003). Gamma-secretase is a membrane protein complex comprised of presenilin, nicastrin, Aph-1, and Pen-2. Proc Natl Acad Sci U S A 100, 6382-6387.

65. Klausner, R. D., Ashwell, G., Van Renswoude, J., Harford, J. B., and Bridges, K. R. (1983). Binding of apotransferrin to K562 cells: explanation of the transferrin cycle. Proceedings of the National Academy of Sciences 80, 2263-2266.

66. Knox, J. J., Hotte, S. J., Kollmannsberger, C., Winquist, E., Fisher, B., and Eisenhauer, E. A. (2007). Phase II study of Triapine ${ }^{\circledR}$ in patients with metastatic renal cell carcinoma: a trial of the National Cancer Institute of Canada Clinical Trials Group (NCIC IND. 161). Investigational new drugs 25, 471-477. 
67. Kokubo, H., Miyagawa-Tomita, S., Nakazawa, M., Saga, Y., and Johnson, R. L. (2005). Mouse hesr1 and hesr2 genes are redundantly required to mediate Notch signaling in the developing cardiovascular system. Dev Biol 278, 301-309.

68. Kopan, R., and Ilagan, M. X. G. (2009). The canonical Notch signaling pathway: unfolding the activation mechanism. Cell 137, 216-233.

69. Kopan, R., Nye, J. S., and Weintraub, H. (1994). The intracellular domain of mouse Notch: a constitutively activated repressor of myogenesis directed at the basic helixloop-helix region of MyoD. Development 120, 2385-2396.

70. Krebs, L. T., Xue, Y., Norton, C. R., Shutter, J. R., Maguire, M., Sundberg, J. P., Gallahan, D., Closson, V., Kitajewski, J., Callahan, R., et al. (2000). Notch signaling is essential for vascular morphogenesis in mice. Genes Dev 14, 1343-1352.

71. Krop, I., Demuth, T., Guthrie, T., Wen, P. Y., Mason, W. P., Chinnaiyan, P., Butowski, N., Groves, M. D., Kesari, S., and Freedman, S. J. (2012). Phase I pharmacologic and pharmacodynamic study of the gamma secretase (Notch) inhibitor MK-0752 in adult patients with advanced solid tumors. Journal of clinical oncology 30, 2307-2313.

72. Kuhnert, F., Kirshner, J. R., and Thurston, G. (2011). DIl4-Notch signaling as a therapeutic target in tumor angiogenesis. Vascular cell 3, 20.

73. Kwok, J. C., and Richardson, D. R. (2002). The iron metabolism of neoplastic cells: alterations that facilitate proliferation? Critical Reviews in Oncology/Hematology 42, 6578.

74. Lammert, E., Brown, J., and Melton, D. A. (2000). Notch gene expression during pancreatic organogenesis. Mech Dev 94, 199-203.

75. Liang, X., Tang, J., Liang, Y., Jin, R., and Cai, X. (2014). Suppression of autophagy by chloroquine sensitizes 5 -fluorouracil-mediated cell death in gallbladder carcinoma cells. Cell \& bioscience $4,10$.

76. List, A. F., Baer, M. R., Steensma, D. P., Raza, A., Esposito, J., Martinez-Lopez, N., Paley, C., Feigert, J., and Besa, E. (2012). Deferasirox reduces serum ferritin and labile plasma iron in RBC transfusion-dependent patients with myelodysplastic syndrome. Journal of clinical oncology 30, 2134-2139.

77. Ludwig, H., Evstatiev, R., Kornek, G., Aapro, M., Bauernhofer, T., Buxhofer-Ausch, V., Fridrik, M., Geissler, D., Geissler, K., Gisslinger, H., et al. (2015). Iron metabolism and iron supplementation in cancer patients. Wien Klin Wochenschr 127, 907-919.

78. Maes, H., Kuchnio, A., Peric, A., Moens, S., Nys, K., De Bock, K., Quaegebeur, A., Schoors, S., Georgiadou, M., Wouters, J., et al. (2014). Tumor vessel normalization by chloroquine independent of autophagy. Cancer Cell 26, 190-206. 
79. Maes, K., Nemeth, E., Roodman, G. D., Huston, A., Esteve, F., Freytes, C., Callander, N., Katodritou, E., Tussing-Humphreys, L., Rivera, S., et al. (2010). In anemia of multiple myeloma, hepcidin is induced by increased bone morphogenetic protein 2. Blood 116, 3635-3644.

80. Malecki, M. J., Sanchez-Irizarry, C., Mitchell, J. L., Histen, G., Xu, M. L., Aster, J. C., and Blacklow, S. C. (2006). Leukemia-associated mutations within the NOTCH1 heterodimerization domain fall into at least two distinct mechanistic classes. Molecular and cellular biology 26, 4642-4651.

81. Manning, B. D., and Cantley, L. C. (2007). AKT/PKB signaling: navigating downstream. Cell 129, 1261-1274.

82. Marshansky, V., and Futai, M. (2008). The V-type H+-ATPase in vesicular trafficking: targeting, regulation and function. Current opinion in cell biology 20,415-426.

83. Massi, D., and Panelos, J. (2012). Notch signaling and the developing skin epidermis. Adv Exp Med Biol 727, 131-141.

84. Mayor, S., and Pagano, R. E. (2007). Pathways of clathrin-independent endocytosis. Nature reviews Molecular cell biology 8, 603.

85. McAuliffe, S. M., Morgan, S. L., Wyant, G. A., Tran, L. T., Muto, K. W., Chen, Y. S., Chin, K. T., Partridge, J. C., Poole, B. B., and Cheng, K.-H. (2012). Targeting Notch, a key pathway for ovarian cancer stem cells, sensitizes tumors to platinum therapy. Proceedings of the National Academy of Sciences 109, E2939-E2948.

86. Milano, J., McKay, J., Dagenais, C., Foster-Brown, L., Pognan, F., Gadient, R., Jacobs, R. T., Zacco, A., Greenberg, B., and Ciaccio, P. J. (2004). Modulation of notch processing by $\mathrm{Y}$-secretase inhibitors causes intestinal goblet cell metaplasia and induction of genes known to specify gut secretory lineage differentiation. Toxicological Sciences 82, 341-358.

87. Minden, M. D., Hogge, D. E., Weir, S. J., Kasper, J., Webster, D. A., Patton, L., Jitkova, Y., Hurren, R., Gronda, M., and Goard, C. A. (2014). Oral ciclopirox olamine displays biological activity in a phase I study in patients with advanced hematologic malignancies. American journal of hematology 89, 363-368.

88. Mori, M., Mahoney, J. E., Stupnikov, M. R., Paez-Cortez, J. R., Szymaniak, A. D., Varelas, X., Herrick, D. B., Schwob, J., Zhang, H., and Cardoso, W. V. (2015). Notch3Jagged signaling controls the pool of undifferentiated airway progenitors. Development 142, 258-267. 
89. Mumm, J. S., Schroeter, E. H., Saxena, M. T., Griesemer, A., Tian, X., Pan, D., Ray, W. J., and Kopan, R. (2000). A ligand-induced extracellular cleavage regulates $Y$-secretaselike proteolytic activation of Notch1. Molecular cell 5, 197-206.

90. Nagaratnam, N., Chetiyawardana, A., and Rajiyah, S. (1978). Aplasia and leukaemia following chloroquine therapy. Postgraduate medical journal 54, 108-112.

91. Nemeth, E., Tuttle, M. S., Powelson, J., Vaughn, M. B., Donovan, A., Ward, D. M., Ganz, T., and Kaplan, J. (2004). Hepcidin regulates cellular iron efflux by binding to ferroportin and inducing its internalization. science 306, 2090-2093.

92. Neufeld, E. J., Galanello, R., Viprakasit, V., Aydinok, Y., Piga, A., Harmatz, P., Forni, G. L., Shah, F. T., Grace, R. F., and Porter, J. B. (2012). A phase 2 study of the safety, tolerability, and pharmacodynamics of FBS0701, a novel oral iron chelator, in transfusional iron overload. Blood 119, 3263-3268.

93. Nichols, J. T., Miyamoto, A., Olsen, S. L., D'Souza, B., Yao, C., and Weinmaster, G. (2007). DSL ligand endocytosis physically dissociates Notch1 heterodimers before activating proteolysis can occur. The Journal of cell biology $176,445-458$.

94. Nofziger, D., Miyamoto, A., Lyons, K. M., and Weinmaster, G. (1999). Notch signaling imposes two distinct blocks in the differentiation of C2C12 myoblasts. Development 126 , 1689-1702.

95. Noguera-Troise, I., Daly, C., Papadopoulos, N. J., Coetzee, S., Boland, P., Gale, N. W., Lin, H. C., Yancopoulos, G. D., and Thurston, G. (2006). Blockade of DII4 inhibits tumour growth by promoting non-productive angiogenesis. Nature 444, 1032-1037.

96. Nutting, C., Van Herpen, C., Miah, A., Bhide, S., Machiels, J.-P., Buter, J., Kelly, C., De Raucourt, D., and Harrington, K. (2009). Phase II study of 3-AP Triapine in patients with recurrent or metastatic head and neck squamous cell carcinoma. Annals of oncology 20 , 1275-1279.

97. O'Neil, J., Grim, J., Strack, P., Rao, S., Tibbitts, D., Winter, C., Hardwick, J., Welcker, M., Meijerink, J. P., and Pieters, R. (2007). FBW7 mutations in leukemic cells mediate $\mathrm{NOTCH}$ pathway activation and resistance to $\mathrm{y}$-secretase inhibitors. The Journal of experimental medicine 204, 1813-1824.

98. Ohkuma, S., and Poole, B. (1978). Fluorescence probe measurement of the intralysosomal $\mathrm{pH}$ in living cells and the perturbation of $\mathrm{pH}$ by various agents. Proceedings of the National Academy of Sciences 75, 3327-3331.

99. Ortica, S., Tarantino, N., Aulner, N., Israël, A., and Gupta-Rossi, N. (2014). The 4 Notch receptors play distinct and antagonistic roles in the proliferation and hepatocytic differentiation of liver progenitors. Faseb j 28, 603-614. 
100. Palomero, T., Lim, W. K., Odom, D. T., Sulis, M. L., Real, P. J., Margolin, A., Barnes, K. C., O'Neil, J., Neuberg, D., and Weng, A. P. (2006). NOTCH1 directly regulates C-MYC and activates a feed-forward-loop transcriptional network promoting leukemic cell growth. Proceedings of the National Academy of Sciences 103, 18261-18266.

101. Palomero, T., Sulis, M. L., Cortina, M., Real, P. J., Barnes, K., Ciofani, M., Caparros, E., Buteau, J., Brown, K., and Perkins, S. L. (2007). Mutational loss of PTEN induces resistance to NOTCH1 inhibition in T-cell leukemia. Nature medicine 13, 1203-1210.

102. Pece, S., Serresi, M., Santolini, E., Capra, M., Hulleman, E., Galimberti, V., Zurrida, S., Maisonneuve, P., Viale, G., and Di Fiore, P. P. (2004). Loss of negative regulation by Numb over Notch is relevant to human breast carcinogenesis. The Journal of cell biology $167,215-221$.

103. Pinnix, Z. K., Miller, L. D., Wang, W., D’Agostino, R., Kute, T., Willingham, M. C., Hatcher, H., Tesfay, L., Sui, G., and Di, X. (2010). Ferroportin and iron regulation in breast cancer progression and prognosis. Science translational medicine 2, 43ra5643 ra56.

104. Prutki, M., Poljak-Blazi, M., Jakopovic, M., Tomas, D., Stipancic, I., and Zarkovic, N. (2006). Altered iron metabolism, transferrin receptor 1 and ferritin in patients with colon cancer. Cancer letters 238, 188-196.

105. Pui, J. C., Allman, D., Xu, L., DeRocco, S., Karnell, F. G., Bakkour, S., Lee, J. Y., Kadesch, T., Hardy, R. R., Aster, J. C., and Pear, W. S. (1999). Notch1 expression in early lymphopoiesis influences B versus T lineage determination. Immunity 11, 299-308.

106. Qian, B.-Z., and Pollard, J. W. (2010). Macrophage diversity enhances tumor progression and metastasis. Cell 141, 39-51.

107. Radtke, F., Wilson, A., Stark, G., Bauer, M., van Meerwijk, J., MacDonald, H. R., and Aguet, M. (1999). Deficient T cell fate specification in mice with an induced inactivation of Notch1. Immunity 10, 547-558.

108. Rangarajan, A., Talora, C., Okuyama, R., Nicolas, M., Mammucari, C., Oh, H., Aster, J. C., Krishna, S., Metzger, D., Chambon, P., et al. (2001). Notch signaling is a direct determinant of keratinocyte growth arrest and entry into differentiation. The EMBO journal 20, 3427-3436.

109. Räsänen, K., and Vaheri, A. (2010). Activation of fibroblasts in cancer stroma. Experimental cell research 316, 2713-2722.

110. Ratikan, J. A., Sayre, J. W., and Schaue, D. (2013). Chloroquine engages the immune system to eradicate irradiated breast tumors in mice. International Journal of Radiation Oncology* Biology* Physics 87, 761-768. 
111. Riccio, O., Van Gijn, M. E., Bezdek, A. C., Pellegrinet, L., Van Es, J. H., Zimber-Strobl, U., Strobl, L. J., Honjo, T., Clevers, H., and Radtke, F. (2008). Loss of intestinal crypt progenitor cells owing to inactivation of both Notch1 and Notch2 is accompanied by derepression of CDK inhibitors p27Kip1 and p57Kip2. EMBO reports 9, 377-383.

112. Ridgway, J., Zhang, G., Wu, Y., Stawicki, S., Liang, W.-C., Chanthery, Y., Kowalski, J., Watts, R. J., Callahan, C., and Kasman, I. (2006). Inhibition of DIl4 signalling inhibits tumour growth by deregulating angiogenesis. Nature 444, 1083-1087.

113. Rishikaysh, P., Dev, K., Diaz, D., Qureshi, W. M., Filip, S., and Mokry, J. (2014). Signaling involved in hair follicle morphogenesis and development. Int J Mol Sci 15, 1647-1670.

114. Robinson, D. R., Kalyana-Sundaram, S., Wu, Y.-M., Shankar, S., Cao, X., Ateeq, B., Asangani, I. A., Iyer, M., Maher, C. A., and Grasso, C. S. (2011). Functionally recurrent rearrangements of the MAST kinase and Notch gene families in breast cancer. Nature medicine 17, 1646.

115. Rock, J. R., Gao, X., Xue, Y., Randell, S. H., Kong, Y. Y., and Hogan, B. L. (2011). Notch-dependent differentiation of adult airway basal stem cells. Cell Stem Cell 8, 639648.

116. Rouault, T. A. (2006). The role of iron regulatory proteins in mammalian iron homeostasis and disease. Nature chemical biology 2, 406-414.

117. Rouschop, K. M., Van Den Beucken, T., Dubois, L., Niessen, H., Bussink, J., Savelkouls, K., Keulers, T., Mujcic, H., Landuyt, W., and Voncken, J. W. (2010). The unfolded protein response protects human tumor cells during hypoxia through regulation of the autophagy genes MAP1LC3B and ATG5. The Journal of clinical investigation 120, 127-141.

118. Rubinsztein, D. C., Codogno, P., and Levine, B. (2012). Autophagy modulation as a potential therapeutic target for diverse diseases. Nature reviews Drug discovery 11,709 730.

119. Sahlgren, C., Gustafsson, M. V., Jin, S., Poellinger, L., and Lendahl, U. (2008). Notch signaling mediates hypoxia-induced tumor cell migration and invasion. Proceedings of the National Academy of Sciences 105, 6392-6397.

120. Scott, C. C., and Gruenberg, J. (2011). Ion flux and the function of endosomes and lysosomes: $\mathrm{pH}$ is just the start: the flux of ions across endosomal membranes influences endosome function not only through regulation of the luminal $\mathrm{pH}$. Bioessays $33,103-$ 110. 
121. Shi, T.-T., Yu, X.-X., Yan, L.-J., and Xiao, H.-T. (2017). Research progress of hydroxychloroquine and autophagy inhibitors on cancer. Cancer chemotherapy and pharmacology 79, 287-294.

122. Shindelman, J. E., Ortmeyer, A. E., and Sussman, H. H. (1981). Demonstration of the transferrin receptor in human breast cancer tissue. Potential marker for identifying dividing cells. International journal of cancer 27, 329-334.

123. Siebel, C., and Lendahl, U. (2017). Notch Signaling in Development, Tissue Homeostasis, and Disease. Physiol Rev 97, 1235-1294.

124. Smith, D. C., Chugh, R., Patnaik, A., Papadopoulos, K. P., Wang, M., Kapoun, A. M., Xu, L., Dupont, J., Stagg, R. J., and Tolcher, A. (2019). A phase 1 dose escalation and expansion study of Tarextumab (OMP-59R5) in patients with solid tumors. Invest New Drugs 37, 722-730.

125. Smith, D. C., Eisenberg, P. D., Manikhas, G., Chugh, R., Gubens, M. A., Stagg, R. J., Kapoun, A. M., Xu, L., Dupont, J., and Sikic, B. (2014). A phase I dose escalation and expansion study of the anticancer stem cell agent demcizumab (anti-DLL4) in patients with previously treated solid tumors. Clin Cancer Res 20, 6295-6303.

126. Steegmann-Olmedillas, J. L. (2011). The role of iron in tumour cell proliferation. Clin Transl Oncol 13, 71-76.

127. Steinman, R. M., Mellman, I. S., Muller, W. A., and Cohn, Z. A. (1983). Endocytosis and the recycling of plasma membrane. The Journal of cell biology 96, 1-27.

128. Sweeney, C., Morrow, D., Birney, Y. A., Coyle, S., Hennessy, C., Scheller, A., Cummins, P. M., Walls, D., Redmond, E. M., and Cahill, P. A. (2004). Notch 1 and 3 receptor signaling modulates vascular smooth muscle cell growth, apoptosis, and migration via a CBF-1/RBP-Jk dependent pathway. Faseb j 18, 1421-1423.

129. Tesfay, L., Clausen, K. A., Kim, J. W., Hegde, P., Wang, X., Miller, L. D., Deng, Z., Blanchette, N., Arvedson, T., Miranti, C. K., et al. (2015). Hepcidin regulation in prostate and its disruption in prostate cancer. Cancer Res 75, 2254-2263.

130. Thompson, B. J., Buonamici, S., Sulis, M. L., Palomero, T., Vilimas, T., Basso, G., Ferrando, A., and Aifantis, I. (2007). The SCFFBW7 ubiquitin ligase complex as a tumor suppressor in T cell leukemia. The Journal of experimental medicine 204, 1825-1835.

131. Timmerman, L. A., Grego-Bessa, J., Raya, A., Bertrán, E., Pérez-Pomares, J. M., Díez, J., Aranda, S., Palomo, S., McCormick, F., and Izpisúa-Belmonte, J. C. (2004). Notch promotes epithelial-mesenchymal transition during cardiac development and oncogenic transformation. Genes \& development 18, 99-115. 
132. Tiyanont, K., Wales, T. E., Siebel, C. W., Engen, J. R., and Blacklow, S. C. (2013). Insights into Notch3 activation and inhibition mediated by antibodies directed against its negative regulatory region. $\mathrm{J}$ Mol Biol 425, 3192-3204.

133. Tolcher, A. W., Messersmith, W. A., Mikulski, S. M., Papadopoulos, K. P., Kwak, E. L., Gibbon, D. G., Patnaik, A., Falchook, G. S., Dasari, A., and Shapiro, G. I. (2012). Phase I study of RO4929097, a gamma secretase inhibitor of Notch signaling, in patients with refractory metastatic or locally advanced solid tumors. Journal of clinical oncology 30 , 2348.

134. Tönnesmann, E., Kandolf, R., and Lewalter, T. (2013). Chloroquine cardiomyopathy - a review of the literature. Immunopharmacol Immunotoxicol 35, 434-442.

135. Traynor, A. M., Lee, J.-W., Bayer, G. K., Tate, J. M., Thomas, S. P., Mazurczak, M., Graham, D. L., Kolesar, J. M., and Schiller, J. H. (2010). A phase II trial of Triapine $($ NSC\# 663249) and gemcitabine as second line treatment of advanced nonsmall cell lung cancer: Eastern Cooperative Oncology Group Study 1503. Investigational new drugs 28, 91-97.

136. Trédan, O., Galmarini, C. M., Patel, K., and Tannock, I. F. (2007). Drug resistance and the solid tumor microenvironment. Journal of the National Cancer Institute 99, 14411454.

137. Vaccari, T., Lu, H., Kanwar, R., Fortini, M. E., and Bilder, D. (2008). Endosomal entry regulates Notch receptor activation in Drosophila melanogaster. The Journal of cell biology $180,755-762$.

138. van Es, J. H., van Gijn, M. E., Riccio, O., van den Born, M., Vooijs, M., Begthel, H., Cozijnsen, M., Robine, S., Winton, D. J., Radtke, F., and Clevers, H. (2005). Notch/Ysecretase inhibition turns proliferative cells in intestinal crypts and adenomas into goblet cells. Nature 435, 959-963.

139. van Tetering, G., van Diest, P., Verlaan, I., van der Wall, E., Kopan, R., and Vooijs, M. (2009). Metalloprotease ADAM10 is required for Notch1 site 2 cleavage. Journal of Biological Chemistry 284, 31018-31027.

140. Verbaanderd, C., Maes, H., Schaaf, M. B., Sukhatme, V. P., Pantziarka, P., Sukhatme, V., Agostinis, P., and Bouche, G. (2017). Repurposing Drugs in Oncology (ReDO)— chloroquine and hydroxychloroquine as anti-cancer agents. ecancermedicalscience 11 .

141. Weng, A. P., Ferrando, A. A., Lee, W., Morris, J. P., Silverman, L. B., Sanchez-Irizarry, C., Blacklow, S. C., Look, A. T., and Aster, J. C. (2004). Activating mutations of NOTCH1 in human T cell acute lymphoblastic leukemia. Science 306, 269-271. 
142. Westhoff, B., Colaluca, I. N., D'Ario, G., Donzelli, M., Tosoni, D., Volorio, S., Pelosi, G., Spaggiari, L., Mazzarol, G., and Viale, G. (2009). Alterations of the Notch pathway in lung cancer. Proceedings of the National Academy of Sciences 106, 22293-22298.

143. White, E. (2012). Deconvoluting the context-dependent role for autophagy in cancer. Nature reviews cancer 12, 401-410.

144. Wolf, R., Wolf, D., and Ruocco, V. (2000). Antimalarials: unapproved uses or indications. Clinics in dermatology 18, 17-35.

145. Wong, G. T., Manfra, D., Poulet, F. M., Zhang, Q., Josien, H., Bara, T., Engstrom, L., Pinzon-Ortiz, M., Fine, J. S., and Lee, H.-J. J. (2004). Chronic treatment with the Ysecretase inhibitor LY-411,575 inhibits $\beta$-amyloid peptide production and alters lymphopoiesis and intestinal cell differentiation. Journal of Biological Chemistry 279, 12876-12882.

146. Wu, L., Aster, J. C., Blacklow, S. C., Lake, R., Artavanis-Tsakonas, S., and Griffin, J. D. (2000). MAML1, a human homologue of Drosophila mastermind, is a transcriptional coactivator for NOTCH receptors. Nature genetics $26,484-489$.

147. Wu, Y., Cain-Hom, C., Choy, L., Hagenbeek, T. J., de Leon, G. P., Chen, Y., Finkle, D., Venook, R., Wu, X., and Ridgway, J. (2010). Therapeutic antibody targeting of individual Notch receptors. Nature 464, 1052-1057.

148. Yahyanejad, S., Theys, J., and Vooijs, M. (2016). Targeting Notch to overcome radiation resistance. Oncotarget 7, 7610 .

149. Yamasaki, T., Terai, S., and Sakaida, I. (2011). Deferoxamine for advanced hepatocellular carcinoma. N Engl J Med 365, 576-578.

150. Yan, M., Callahan, C. A., Beyer, J. C., Allamneni, K. P., Zhang, G., Ridgway, J. B., Niessen, K., and Plowman, G. D. (2010). Chronic DLL4 blockade induces vascular neoplasms. Nature 463, E6-7.

151. Yan, Y., Denef, N., and Schüpbach, T. (2009). The vacuolar proton pump, V-ATPase, is required for notch signaling and endosomal trafficking in Drosophila. Developmental cell 17, 387-402.

152. Zeidner, J. F., Karp, J. E., Blackford, A. L., Smith, B. D., Gojo, I., Gore, S. D., Levis, M. J., Carraway, H. E., Greer, J. M., and Ivy, S. P. (2014). A phase II trial of sequential ribonucleotide reductase inhibition in aggressive myeloproliferative neoplasms. Haematologica 99, 672-678.

153. Zhu, T. S., Costello, M. A., Talsma, C. E., Flack, C. G., Crowley, J. G., Hamm, L. L., He, X., Hervey-Jumper, S. L., Heth, J. A., and Muraszko, K. M. (2011). Endothelial cells 
Chapter I

create a stem cell niche in glioblastoma by providing NOTCH ligands that nurture selfrenewal of cancer stem-like cells. Cancer research 71, 6061-6072. 


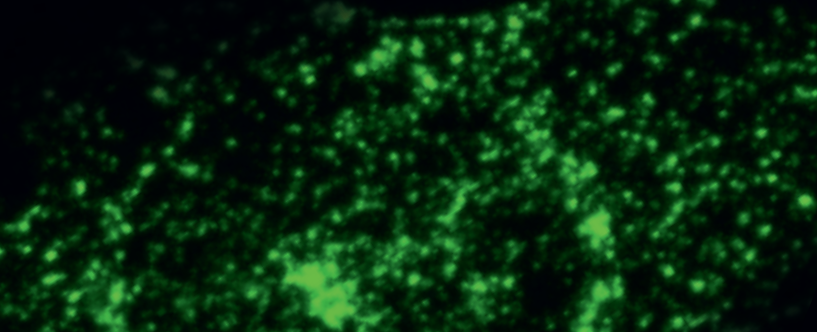

$$
\begin{aligned}
& 3^{3}+0^{2}
\end{aligned}
$$

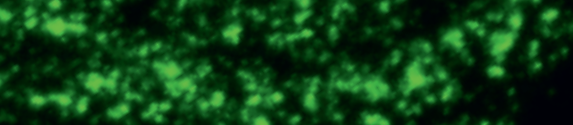

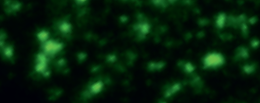

$$
\begin{aligned}
& \text { CHAPTER II }
\end{aligned}
$$




\section{The role of intracellular trafficking of Notch receptors in Notch signaling activation (review)}

\section{Judith Hounjet and Mtarc Vooijs}

Department of Radiation Oncology (Maastro), GROW School for Oncology, Maastricht University Medical Centre+, Maastricht, The Netherlands

Maastro clinic, Maastricht, The Netherlands

\#Corresponding author: marc.vooijs@maastrichtuniversity.nl, Tel: +31 (0)433882912 


$$
\begin{gathered}
\text { C. } \\
\text { CHAPTER || }
\end{gathered}
$$




\section{The antimalarial drug chloroquine sensitizes oncogenic NOTCH1 driven human T-ALL to $\mathrm{Y}$-secretase inhibition}

Judith Hounjet ${ }^{1,2}$, Roger Habets ${ }^{1}$, Marco B. Schaaf', Tessa C. Hendrickx', Lydie M.O. Barbeau', Sanaz Yahyanejad', Kasper M. Rouschop ${ }^{1}$, Arjan J. Groot ${ }^{1}$, and Marc Vooijs ${ }^{1,2 \#}$

${ }^{1}$ Department of Radiation Oncology (Maastro), GROW School for Oncology, Maastricht University Medical Centre+, Maastricht, the Netherlands ${ }^{2}$ Maastro clinic, Maastricht, The Netherlands 


\section{Graphical abstract}

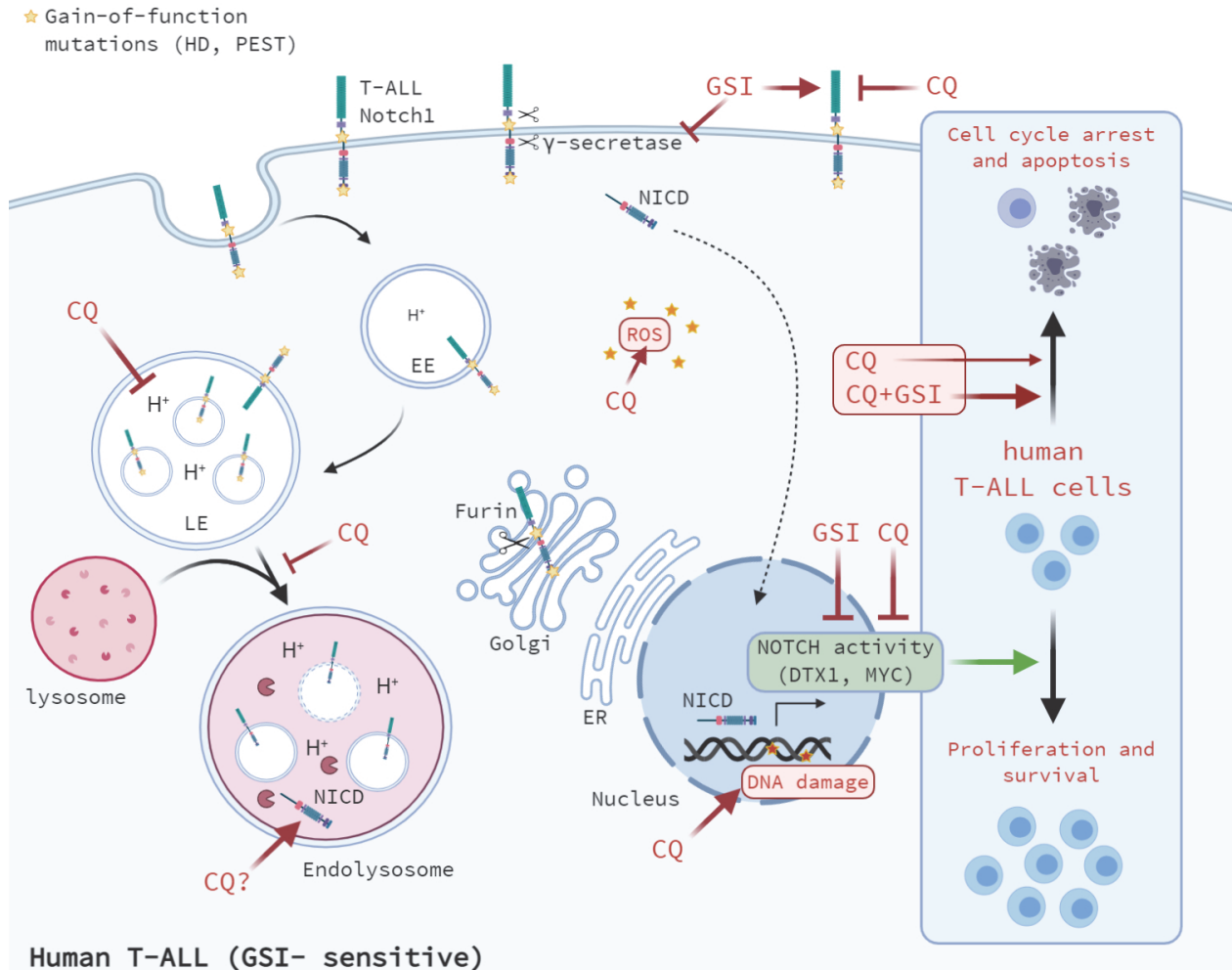




\section{Abstract}

T-cell acute lymphoblastic leukemia (T-ALL) is an aggressive cancer arising from Tcell progenitors. Although current treatments, including chemotherapy and glucocorticoids, have significantly improved survival, T-ALL remains a fatal disease and new treatment options are needed. Since more than $60 \%$ of T-ALL cases bear oncogenic NOTCH1 mutations, small molecule inhibitors of NOTCH1 signalling; $\gamma$ secretase inhibitors (GSI), are being actively investigated for the treatment of T-ALL. Unfortunately, GSI have shown limited clinical efficacy and dose-limiting toxicities. We hypothesized that by combining known drugs, blocking NOTCH activity through another mechanism, may synergize with GSI enabling equal efficacy at a lower concentration. Here, we show that the clinically used antimalarial drug chloroquine (CQ), an inhibitor of lysosomal function and autophagy, decreases T-ALL cell viability and proliferation. This effect of CQ was not observed in GSI-resistant T-ALL cell lines. Mechanistically, CQ impairs the redox balance, induces ds DNA breaks, and activates the DNA damage response. CQ also interferes with intracellular trafficking and processing of oncogenic NOTCH1. Interestingly, we show for the first time that the addition of $C Q$ to $Y$-secretase inhibition has a synergistic therapeutic effect on $T$ ALL and reduces the concentration of GSI required to obtain a reduction in cell viability and a block of proliferation. Overall, our results suggest that $C Q$ may be a promising repurposed drug in the treatment of T-ALL, as a single treatment or in combination with GSI, increasing the therapeutic ratio. 


\section{Introduction}

T-cell acute lymphoblastic leukemia (T-ALL) is a very aggressive, acute cancer that accounts for $15 \%$ of pediatric and $50 \%$ of adult leukemia's. Standard treatment consists of chemotherapy combined with glucocorticoids. While about $80 \%$ of children and $50 \%$ of adults can be cured, a significant percentage is resistant to primary treatment or remains at risk for relapse. Thus, although current treatments have significantly improved survival, T-ALL still remains a fatal disease and new treatment options are required (Marks et al., 2009).

In T-ALL, specific molecular classes exist based on mutations and translocations in multiple T-cell oncogenes (Ferrando et al., 2002). The most common alterations found in T-ALL are mutations in NOTCH1, leading to ligandindependent activation of $\mathrm{NOTCH} 1$ driving proliferation and survival in up to $60 \%$ of T-ALL cases (Mansour et al., 2006; Weng et al., 2004). NOTCH1 has essential roles in cell fate decisions within the hematopoietic system and is required to adopt T-cell fates from lymphoid progenitors, explaining the strong selection for oncogenic NOTCH1 mutations in T-ALL (Radtke et al., 1999). The frequent involvement of NOTCH1 in T-ALL resulted in the development of small molecule inhibitors targeting the NOTCH1 receptor pathway. The most widely used are $\mathrm{Y}$-secretase inhibitors (GSI) that prevent proteolytic cleavage of $\mathrm{NOTCH}$ and the downstream activation of target genes. Unfortunately, clinical trials have shown limited anti-leukemic activity of $y$-secretase inhibition and dose-limiting toxicities in normal tissues, most notably causing goblet cell metaplasia in the intestine resulting in severe diarrhoea (Milano et al., 2004; Wong et al., 2004).

Recent evidence indicates that $\mathrm{Y}$-secretase activity not only occurs at the cell surface, but also in the acidic environment of the lysosomes and endosomes (Kaether et al., 2006; Pasternak et al., 2003; Tagami et al., 2008). Ligand-dependent $\mathrm{NOTCH}$ signalling requires V-ATPase activity, suggesting that acidification is essential for NOTCH signalling (Sethi et al., 2010; Vaccari et al., 2010). In addition, it was shown that a defective endosomal pathway, regulating NOTCH degradation, results in ligand-independent activation within the lysosomes due to accumulation of NOTCH (Childress et al., 2006; Jaekel and Klein, 2006; Maes et al., 2014; Vaccari 
et al., 2010). Interestingly, depletion of Rab7, required for the fusion between the late endosome and the lysosome, suppressed ligand-independent, but not liganddependent signalling (Schneider et al., 2013). Altogether, these findings suggest that endosomes play a key role in the NOTCH signal relay and that fusion with the lysosomes is a prerequisite for ligand-independent signalling. Therefore, a potent intervention to block ligand-independent $\mathrm{NOTCH}$ signalling may be to inhibit lysosomal function by increasing the $\mathrm{pH}$ of the lysosomal lumen.

An FDA-approved drug that has such a mode of action is chloroquine (CQ), which is an extensively clinically used antimalarial drug with an acceptable toxicity profile. Accumulating data indicate that $\mathrm{CQ}$ has anti-cancer activity and has been widely investigated as a sensitizer of radio- and chemotherapy (Ding et al., 2011; Liang et al., 2014; Ratikan et al., 2013; Rouschop et al., 2010; Verbaanderd et al., 2017). Therefore, $C Q$ has recently been included in several clinical trials to investigate safety and efficacy in a broad range of malignancies (Shi et al., 2017).

The anti-cancer activity of $C Q$ was previously mostly attributed to its effect of blocking autophagy (Degenhardt et al., 2006), a major vesicular pathway to recycle damaged/obsolete cytoplasmic components via lysosomes. However, blockade of lysosomal acidification generates additional, autophagy-independent effects as well (Eng et al., 2016). Interestingly, CQ has been shown to phosphorylate ataxia-telangiectasia mutated (ATM), one of the upstream DNA damage response (DDR) kinases, in the absence of detectable DNA damage, leading to activation of the DDR. Subsequent activation of $\mathrm{p} 53$ and its downstream target $\mathrm{p} 21^{\mathrm{CIP} 1}$ have been shown to result in a cell cycle arrest in several cancer types (Bakkenist and Kastan, 2003; Hu et al., 2016; Loehberg et al., 2007; Maclean et al., 2008). Moreover, recent evidence showed that $C Q$ up-regulates $p 53$ expression by reactive oxygen species (ROS) accumulation induced by the loss of lysosomal and mitochondrial membrane potential in colorectal cancer cell lines (Chen et al., 2017). Furthermore, it has been demonstrated that autophagy is up-regulated upon p53 activation, enabling tumour cells to escape from apoptosis in a Myc-induced lymphoma model (Amaravadi et al., 2007). Together these data suggest a complex interaction between autophagy, DNA 
damage response, and redox balance in tumour cell survival creating a therapeutic opportunity for $\mathrm{CQ}$ treatment.

Therefore, we questioned whether $C Q$ would suppress the viability and proliferation of T-ALL cells that rely on ligand-independent NOTCH1 signalling for their survival and whether combined treatment of GSI and CQ would have an additional effect on T-ALL survival as compared to GSI alone. Here, we show for the first time that $C Q$ decreases T-ALL cell viability and proliferation, which was not observed in GSI-resistant T-ALL cell lines. Moreover, CQ treatment decreases the concentration of GSI required to reduce T-ALL cell proliferation and shows an additional effect when combined with $\mathrm{Y}$-secretase inhibitors. Mechanistically, $\mathrm{CQ}$ impairs the redox balance and induces DNA damage with a subsequent activation of the DNA damage response (DDR). When CQ was combined with GSI treatment, a major cell cycle arrest was shown with a synergistic increase in apoptosis. Furthermore, $\mathrm{CQ}$ also interferes with the intracellular trafficking and processing of oncogenic NOTCH1. Together, our findings provide new insights in the mechanisms by which $C Q$ impacts on cancer cell survival and identify opportunities to enhance treatment effects in NOTCH1 driven T-ALL.

\section{Materials and Methods}

\section{Cell lines, compounds and constructs}

All T-ALL cell lines used were kind gifts from J Meijerink (Erasmus MC Rotterdam, The Netherlands). GSI-sensitive (ALL-SIL, HPB-ALL, and DND41) and GSI-resistant (Jurkat and CCRF-CEM) T-ALL cell lines were maintained in RPMI-1640 containing 10\% FBS, 2 mM GlutaMAX ${ }^{\mathrm{TM}}$ (Thermofisher) and 50U/mL Penicillin/Streptomycin. U2OS cells were maintained in DMEM (Dulbecco's Modified Eagle's medium) containing 10\% FBS and 50U/mL Penicillin/Streptomycin. All cell lines were regularly tested for mycoplasma contamination. Cells were once treated with dimethyl sulfoxide (DMSO), $0.2 \mu \mathrm{M}$ of $\mathrm{y}$-secretase inhibitor dibenzazepine (DBZ), $1 \mu \mathrm{M}$ of $\mathrm{N}$ [N-(3,5-Difluorophenacetyl)-L-alanyl]-S-phenylglycine t-butyl ester (DAPT), $1 \mu \mathrm{M}$ of BMS-906024 (a kind gift from Bristol-Myers Squib) prepared in DMSO (Syncom, Groningen, The Netherlands), $15 \mu \mathrm{M}$ of Chloroquine, $1 \mathrm{nM}$ of Bafilomycin A1 (Sigma) 
or a combined treatment at day 0 . After this single treatment, cells were followed up for 4 or 7 days, as indicated. Chloroquine diphosphate salt (Sigma Aldrich) was dissolved in deionized water. PCR amplified fragment from monomeric RFP (Campbell et al., 2002) was Mlu1-Xba1 cloned into the murine N1 $\Delta \mathrm{E}-\mathrm{Myc}$ (van Tetering et al., 2009), replacing the Myc tag with a monomeric RFP tag. The pEGFPLC3 construct (Kabeya et al., 2000) was a kind gift from N. Mizushima, from which GFP-LC3 was cloned into a pQCXIP vector using Agel/EcoRI restriction sites.

\section{Cell viability, proliferation and apoptosis assay}

Trypan blue (Sigma Aldrich) exclusion was used to analyse GSI-sensitive and GSIresistant T-ALL cell viability and living cells using a TC20 ${ }^{\mathrm{TM}}$ Automated Cell Counter (Biorad). To determine cell viability and IC50 values CellTiter-Glo Cell Viability assay (Promega, G9682) was used according to the manufacturer's protocol after T-ALL cells were treated with a dilution range of $D B Z$ or $C Q$. In short, at 7 days posttreatment CellTiter-Glo was added to the medium (1:1). Cells were lysed for $5 \mathrm{~min}$ on an orbital shaker and subsequently incubated for $25 \mathrm{~min}$ at room temperature. Luminescence was measured with an integration time of $0.5 \mathrm{~s}$ using a filter-based multi-mode microplate reader (FLUOstar Omega, BMG Labtech). IC50 values of $D B Z$ and $C Q$ were estimated with the curve of the log (inhibitor) vs. response (Variable slope). To measure apoptosis a Pacific Blue ${ }^{\mathrm{TM}}$ Annexin V/SYTOX ${ }^{\mathrm{TM}}$ AADvanced ${ }^{\mathrm{TM}}$ Apoptosis Kit for flow cytometry (Thermofisher) was used according to the manufacturer's protocol. As a positive control ALL-SIL cells were treated with $10 \mu \mathrm{M}$ of etoposide for 24 hours to induce apoptosis (data not shown). The number of cells in early and late apoptosis was analysed using a FACSCantoll cytometer with BD FACSDiva 6.1.1 software. Using FLowV10.1 doublets and cellular debris were excluded.

\section{Immunoblotting}

Cell lysates were prepared in $1 \mathrm{x}$ Laemlli loading buffer. Proteins were separated on Tris-HCL SDS-PAGE gels and transferred onto PVDF membranes. Membranes were blocked in 5\% dried skimmed milk (Marvel) and 0.05\% Tween20 in TBS. 
Protein detection was performed with subsequent primary antibodies: rabbit anticleaved caspase-3 Asp175 (5A1E)(Cell Signaling, cat. \#9664, 1:1 000), rabbit anticleaved-PARP Asp214 (Cell Signaling, cat. \#9541, 1:1 000), rabbit anti-LC3 (MBL International, cat. \#PM036, 1:1 000), rabbit anti-Notch1 (D1E11) XP (Cell Signaling, cat. \#3608 1:1 000), cleaved Notch1 (Val 1744)(D3B8)(Cell Signaling, \#4147S, 1:1 000), rabbit anti-phospho-ATM (EP1890Y)(Abcam, cat. \# ab81292, 1:1 000), mouse anti-ATM (Sigma Aldrich, cat. \#A1106, 1:1 000), rabbit anti-phospho-Chk2 (T68) (C13C1)(Cell Signaling, cat. \#2197S, 1:1 000), rabbit anti-phospho-Chk1 (Ser345)(133D3) (Cell Signaling, cat. \#2348S, 1:1 000), mouse anti-P53 D0-7 (Santa Cruz, cat. \#sc-47698, 1:1 000), mouse anti-actin clone C4 (MP Biomedicals, cat. \# 691001, 1:20 000) and mouse anti-P62 (BD Biosciences, cat. \# 610832, 1:1 000). Secondary antibodies used were anti-mouse (Cell Signaling, cat. \#7076S, 1:5 000) or rabbit IgG-horseradish peroxidase (Cell Signaling, cat. \#7074S, 1:5 000). Amersham ECL Prime Western Blotting Detection Reagent (GE Healthcare) was used for visualization as described by the manufacturer.

\section{Quantitative PCR}

Total RNA was isolated using NucleoSpin RNA (Macherey-Nagel) from cells treated with DMSO, DBZ, CQ or combinational treatment at 4 days post-treatment according to the manufacturer's protocol. cDNA was obtained using Iscript CDNA synthesis kit (Biorad) followed by SYBR-green based reverse transcription quantitative PCR (RTPCR) using SensiMix SYBR high-ROX kit (GC Biotech). mRNA expression was analysed using $3 \mu \mathrm{M}$ of forward and reverse primers (Supplementary Table 1). Cycle threshold $(\mathrm{Ct})$ values were analysed with CFX Connect Real Time System (Biorad) and RPL13A was used as a housekeeping gene.

\section{NOTCH receptor flow cytometry}

NOTCH receptor availability on the cell surface was analysed by flow cytometry. ALLSIL cells were fixed in 4\% PFA and stained with a PE labelled mouse anti-human $\mathrm{NOTCH} 1$ antibody targeting the extracellular domain of NOTCH1 (Biolegend, cat. \#352105) at 4 days post-treatment. A PE labelled mouse IgG1K was used as an 
isotype control (Biolegend). After staining, cells were analyzed using a FACSCantoll cytometer with BD FACSDiva 6.1.1 software. Using FLowV10.1 doublets and cellular debris were excluded. Mean fluorescent intensity (MFI) was determined and normalized to the control to obtain the Fold-Change in extracellular NOTCH1 receptor expression.

\section{Cell cycle, DNA damage and cytoplasmic ROS analysis}

Cell cycle analysis was performed using Click-iT ${ }^{\mathrm{TM}}$ Plus EdU Pacific Blue ${ }^{\mathrm{TM}}$ Flow Cytometry Assay Kit (Thermofisher) in combination with Propidium lodide (PI) staining. Edu was incorporated for 1 hour at $37^{\circ} \mathrm{C}$ in cell culture conditions. The ClickiT reaction was performed according to the manufacturer's protocol. For PI staining cells were incubated with $1 \mu \mathrm{g} / \mathrm{ml}$ of PI, $100 \mu \mathrm{g} / \mathrm{ml}$ of RNAse A and $0.1 \%$ TritonX-100 in PBS for 30 min at RT. An unstained, PI only, Edu only, and Click-iT only sample were used for compensation and correction for background and auto-fluorescence.

DNA damage was analysed by $\mathrm{YH} 2 \mathrm{AX}$ expression. In short, cells treated with DMSO, DBZ, CQ, and the combinational treatment were fixed in 1\% PFA and stored in $70 \%$ ethanol at $-20^{\circ} \mathrm{C}$ overnight at 4 and 7 days post-treatment. Cells were stained overnight at $4^{\circ} \mathrm{C}$ with $1 \mu \mathrm{g}$ of FITC conjugated mouse anti-phospho-Histone H2A.X (Ser139)(JBW301) (Merck, cat. \#16-202A) in 1\% BSA and 0.2\% Triton X100 in PBS. As a control, ALL-SIL cells were irradiated with $2 \mathrm{~Gy}$ and stained for $\mathrm{YH} 2 \mathrm{AX}$ at 1.5 hours post-irradiation. An unstained sample was used to correct for auto fluorescence.

Cytoplasmic ROS levels were analysed by incubating ALL-SIL cells treated with DMSO, DBZ, CQ, and the combinational treatment with $5 \mu \mathrm{M}$ of CellROX Deep Red Reagent (Thermofisher) in serum free medium at $37^{\circ} \mathrm{C}$ for $30 \mathrm{~min}$. As controls, ALL-SIL cells were (pre-incubated with $10 \mathrm{mM}$ of N-Acetylcysteine (Sigma Aldrich) overnight and) incubated with $250 \mu \mathrm{M}$ of $\mathrm{H}_{2} \mathrm{O}_{2}$ for $15 \mathrm{~min}$ at $37^{\circ} \mathrm{C}$ in serum free medium prior to CellROX staining. For cell cycle, DNA damage, and cytoplasmic ROS analysis a FACSCantoll cytometer with BD FACSDiva 6.1.1 software was used. FlowJo V10.1 was used to: exclude doublets and cellular debris, determine the distribution of cells within G0-G1, S, and G2-M phase, and to analyze the mean 
fluorescent intensity (MFI). MFI was normalized to the DMSO control to obtain the Fold-Change in $\mathrm{yH} 2 \mathrm{AX}$ and cytoplasmic ROS levels.

\section{Transfection and N1ICD staining}

U2OS cells were transfected with Polyethylenimine (Pei)(Polysciences, cat. \#23966) to express $\triangle \mathrm{E}-\mathrm{RFP}$ (and GFP-LC3). At 24h hours post-transfection cells were treated once with DMSO, DBZ, CQ, or combined treatment. Cells were fixed in $4 \%$ paraformaldehyde, incubated in $50 \mathrm{mM}$ of Glycine, and nuclei were stained with Dapi at 24 hours post-treatment. For N1ICD staining, cells were permeabilized with $0.1 \%$ triton $\mathrm{X}$ in PBS after Glycine incubation and blocked in 1\% BSA for 30 min at RT. Cells were incubated with rabbit anti-cleaved Notch1 (Val 1744)(D3B8)(Cell Signaling, cat. \#4147S, 1:100) for 1 hour at RT, washed in PBS, and incubated with goat anti-Rabbit IgG- Alexa Fluor 488 (Invitrogen, cat. \#A11008, 1: 500) for 30 minutes at RT. Microscopic analysis was performed using an inverted Leica SPE confocal microscope and Leica LAS AF Lite software.

\section{Statistical analysis}

Data are presented as mean including the standard error of the mean (SEM) of three independent experiments. Statistical analyses were performed using GraphPad Prism 5 and statistical significance was defined as $p$-value $<0.05$.

\section{Results}

\section{Chloroquine inhibits T-ALL cell proliferation and induces apoptosis}

\section{synergistically when combined with $\mathrm{y}$-secretase inhibition in vitro}

Because recent evidence indicates that $y$-secretase activity not only occurs at the cell surface, but also in vesicles, we addressed whether blocking vesicle function with $C Q$ would attenuate the survival of T-ALL cells requiring ligand-independent NOTCH1 signalling for their survival. To answer this question, GSI-sensitive T-ALL cell lines (ALL-SIL, DND41, and HPB-ALL) were treated once with DMSO, the Ysecretase inhibitor $\mathrm{DBZ}, \mathrm{CQ}$, or a combination of $\mathrm{DBZ}$ and $\mathrm{CQ}$. Indeed, $\mathrm{DBZ}$ treatment significantly reduced the number of living ALL-SIL cells as compared to 
controls (Figure 1A), while the effect on cell viability was only minor at 7 days posttreatment (Figure 1B). Interestingly, ALL-SIL cells treated with $C Q$ showed a significant decrease in cell viability that was accompanied with a significant lower number of living cells compared to vehicle treated cells. Combining DBZ and CQ showed additional inhibitory effects on ALL-SIL cell viability at 7 days post-treatment compared to single treatments. Similar observations were made in other GSIsensitive T-ALL cell lines (HPB-ALL and DND41) in which $Y$-secretase inhibition significantly reduced both cell viability and proliferation (Figure S1A, S1B). Consistent with these findings, combination treatment of DBZ and CQ in HPB-ALL and DND41 cells had a stronger effect on cell viability compared to single treatments. Interestingly, CQ treatment showed a similar effect in HPB-ALL cells, whereas in DND41 cells the number of living cells was reduced at 7 days post-treatment without a significant effect on cell viability. We obtained similar results using a structurally distinct $y$-secretase inhibitor, DAPT, as single treatment or when combined with $\mathrm{CQ}$ (Figure S1C), which also effectively blocked Val1744 N1ICD cleavage at 7 days post-treatment (Figure S1D). As expected, $\gamma$-secretase inhibition had no effect (Palomero et al., 2007) on cell viability in GSI-resistant T-ALL cell lines (CCRF-CEM and Jurkat) (Figure S2A, S2B), despite the fact that DBZ was effective in blocking NOTCH1 Val1744 cleavage and N1ICD formation (Figure S2C). In Jurkat cells, but not in CCRF-CEM, GSI reduced cell proliferation. Neither CQ nor combined treatment had an effect on GSI-resistant T-ALL cell viability, while both treatments showed a significant reduction in GSI-resistant T-ALL cell proliferation.

To test whether the effect of DBZ could be extrapolated to $y$-secretase inhibition in general, ALL-SIL cells were treated with DAPT or BMS906024 as a single treatment and combined with $C Q$. Both structurally different $y$-secretase inhibitors showed similar results on cell viability and proliferation compared to DBZ treatment (Figure S3A, S3B). Bafilomycin A1(BAFA), a V-ATPase inhibitor which, like $C Q$, inhibits lysosomal and endosomal fusion (Yoshimori et al., 1991), also significantly decreased ALL-SIL cell proliferation, and reduced cell viability albeit not significantly. However, BAFA treatment combined with GSI did significantly decrease 
A

ALL-SIL

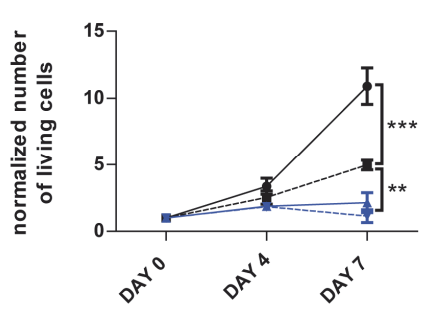

C

DAY 7

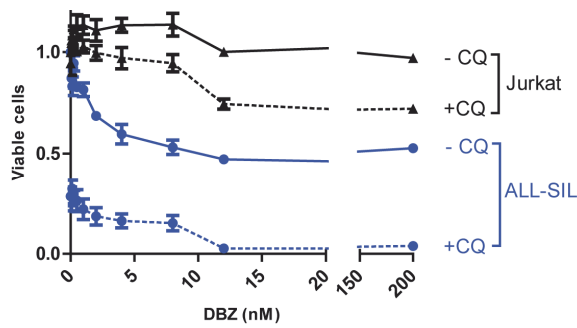

E

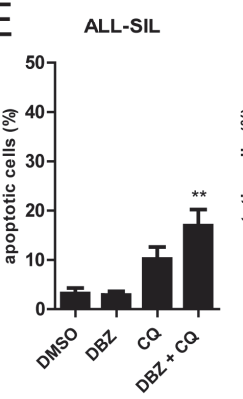

G

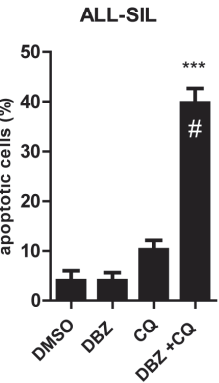

ALL-SIL DAY 7
B

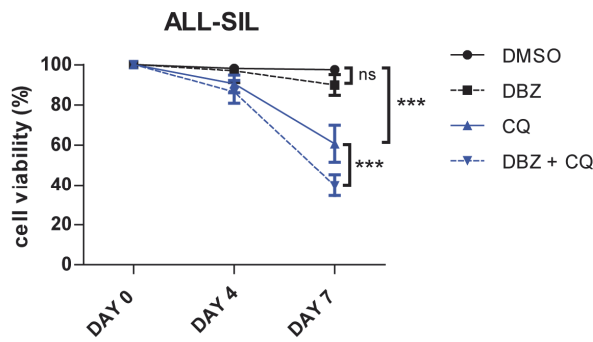

D

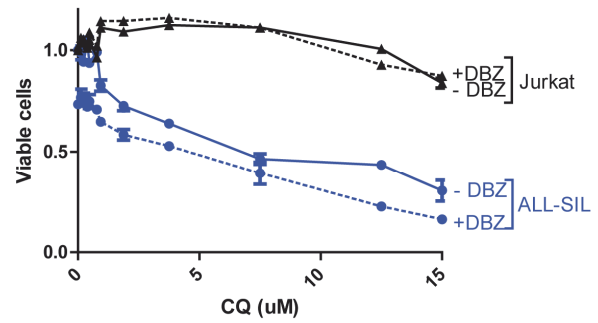

F

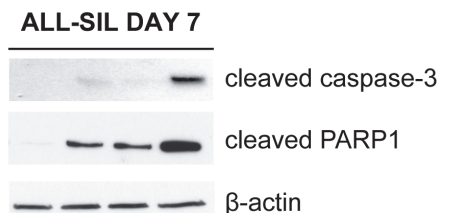

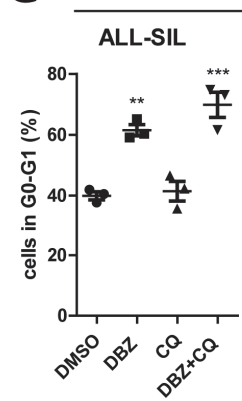
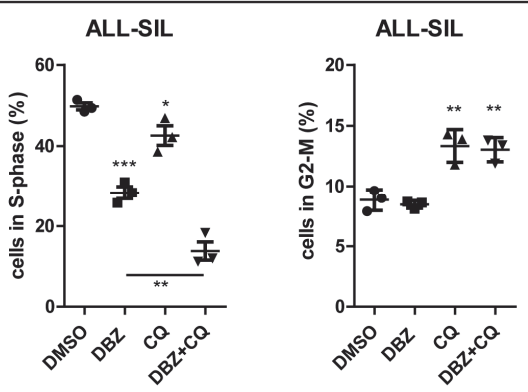

Figure 1. Chloroquine inhibits T-ALL cell viability and survival when combined with GSI. A) Time course of the number of living ALL-SIL cells treated once with DMSO, DBZ, $C Q$, or combined treatment followed until 7 days post-treatment (2-Way ANOVA, ${ }^{* *} P<0.01$, $\left.{ }^{* *} P<0.001\right)$. B) Cell viability time course of $A L L-S I L$ cells treated once with DMSO, DBZ, CQ, 
or combined treatment followed until 7 days post-treatment (2-Way ANOVA, ns: nonsignificant, $\left.{ }^{* \star *} P<0.001\right)$. C) Assessment of viable T-ALL cells, both GSI-sensitive (ALL-SIL) and GSI-resistant (Jurkat), using CellTiter Glo cell viability assay. T-ALL cells were treated once with a dilution range of $D B Z(I C 50=2.0 \mathrm{nM})$ with or without $15 \mu \mathrm{M}$ of $C Q$ and cell viability was determined at 7 days post-treatment. D) GSI-sensitive (ALL-SIL) and GSI-resistant (Jurkat) T-ALL cells were treated once with a dilution range of CQ (IC5O $=14.2 \mu M)$ with or without $2 \mathrm{nM}$ of DBZ. CellTiter Glo cell viability assay was used to determine cell viability at 7 days post-treatment. E) Quantification of the total percentage of early and late apoptotic ALL-SIL cells based on Annexin V and SYTOX AADvanced flow cytometry at 4 (left) and 7 (right) days post-treatment (1-Way ANOVA (Tukey comparison), ${ }^{* *} P<0.01,{ }^{* * *} P<0.001$, significant compared to DMSO). "Synergy was determined (2-Way ANOVA, ${ }^{* * *} P<0.001$ ). F) Immunoblot analysis of cleaved-PARP1, cleaved-caspase-3 and $\beta$-actin (loading control) protein levels at 7 days post-treatment in ALL-SIL cells. G) Quantitative overview of the percentages of cells in G0-G1, S-, and G2-M phase in ALL-SIL cells at 7 days post-treatment assessed by Edu incorporation and Propidium lodide (PI) staining (1-Way ANOVA (Tukey comparison), ${ }^{*} P<0.05,{ }^{* *} P<0.01,{ }^{* *} P<0.001$, significant compared to DMSO). DBZ: $y$ secretase inhibitor dibenzoazepine, CQ: chloroquine. Data are representative of three independent experiments and values are expressed in mean \pm SEM.

ALL-SIL cell viability and proliferation, although this effect was not as strong as observed with DBZ and CQ. All three GSI's (DBZ, DAPT, and BMS) blocked NOTCH1 Val1744 cleavage (Figure S3C). In contrast, both CQ and Bafilomycin treatment showed an accumulation of N1ICD-Val1744. CQ treatment resulted in the accumulation of two TransMembrane/IntraCellular fragments (TMIC) NOTCH1 proteins derived from wild type and mutated allele (L1594P, $\triangle$ PEST) (Weng et al., 2004), and the membrane bound (S2) cleaved form, Notch Extracellular Truncation (NEXT). Interestingly, we detected a Val1744 fragment of higher molecular weight in CQ-treated ALL-SIL cells. The accumulation of NOTCH1 proteins was only observed with $C Q$ and not observed with BAFA treatment.

Furthermore, we tested whether there was a dose dependent effect of DBZ and CQ on cell viability using a CellTiter Glo, which measures ATP producing (viable) cells. Both DBZ (Figure 1C) and CQ (Figure 1D) treatment showed a dosedependent decrease in ALL-SIL viability at 7 days post-treatment with an IC50 of 2.0 
$( \pm 0.1) \mathrm{nM}$ of DBZ and $14.2( \pm 0.2) \mu \mathrm{M}$ of $\mathrm{CQ}$. Notably, a dose of $12.5 \mathrm{nM}$ of DBZ showed a similar decrease in the number of living cells compared to a dose of 200 nM of DBZ. GSI-resistant Jurkat cells did not show a dose-dependent effect of DBZ or $C Q$, although $C Q$ showed a small inhibitory effect on Jurkat cell viability at $15 \mu \mathrm{M}$. Moreover, both the addition of $\mathrm{CQ}(15 \mu \mathrm{M})$ to the $\mathrm{DBZ}$ dilution range and the addition of DBZ (2 $\mathrm{nM}$ ) to the CQ dilution range further decreased ALL-SIL cell viability. These data indicate that a lower dose of GSI can be used to obtain a similar decrease in TALL cell viability when combined with $C Q$. A similar dose-dependent effect on cell viability by DBZ treatment was also shown in HPB-ALL cells (Figure S3D), which was further reduced by the addition of CQ. However, HPB-ALL cells showed to be significantly more sensitive to GSI inhibition compared to ALL-SIL cells (Figure S3E).

Next, we investigated if apoptosis was the mechanism by which single and combined treatment reduced cell viability in T-ALL by using Annexin VIAAD staining. In ALL-SIL cells, the total percentage of early and late apoptotic cells was not affected by $\mathrm{Y}$-secretase inhibition at 4 and 7 days post-treatment (in accordance with a main effect on proliferation rather than survival as observed previously), but $C Q$ increased the number of Annexin V+ and AAD+ cells by $10 \%(p$-value $=0.09)$ at 4 days post-treatment (Figure 1E). This effect was significantly enhanced in cells treated with both DBZ and CQ at 4 and 7 days post-treatment resulting in $17 \%$ and $40 \%$ of apoptotic cells, respectively, compared to $5 \%$ in vehicle-treated controls. These findings were supported by increased protein levels of cleaved caspase- 3 and cleaved PARP1 at 7 days post-treatment (Figure 1F). These data are in line with our cell viability results and show that $C Q$ attenuates T-ALL cell viability and induces apoptosis, especially in combination with $\mathrm{Y}$-secretase inhibition, which showed a synergistic effect. In HPB-ALL cells combined treatment also showed a synergistic increase in the number of apoptotic cells (80\%) at 7 days post-treatment (Figure S3F). Interestingly, DBZ treatment showed also a high number (20\%) of early apoptotic cells, which combined with late apoptotic cells increased to $40 \%$ of HPBALL cells in apoptosis. Moreover, when a DBZ dose of $12.5 \mathrm{nM}$ (16 fold lower) was added, which effectively blocked N1ICD formation (Figure S4A), we could still obtain a synergistic effect with $20 \%$ of apoptotic cells in the combined treatment. GSI- 
resistant cell lines did not show high numbers of apoptotic cells when combined treatment was applied (Figure S4B).

\section{Chloroquine enhances the cell cycle block exerted by GSI treatment}

As indicated before, there may be a link between $C Q$ treatment and cell cycle arrest due to $p 53$ activation. Therefore, we first investigated whether $C Q$ was able to induce alterations in cell cycle progression, as single and combined treatment with DBZ, by assessing EdU incorporation and $\mathrm{PI}$ for labelling DNA content by flow cytometry. In ALL-SIL cells, DBZ treatment increased the number of cells in G0/G1 phase with a concomitant reduction of cells in S-phase at 4 days post-treatment (data not shown). This effect was strongly enhanced at 7 days post-treatment where DBZ caused a $20 \%$ increase in G0/G1 and a two-fold reduction in S-phase cells (Figure 1G). While $\mathrm{CQ}$ as single treatment showed only minor effects, it augmented the effect of DBZ by reducing the proportion the cells in S-phase from 28\% (DBZ alone) to $14 \%$ (combination treatment) with $70 \%$ of cells arresting in G0/G1 phase at 7 days posttreatment. Furthermore, $C Q$ treatment showed a mild, but significant, increase in the percentage of cells in G2-M. HPB-ALL cells were more sensitive to GSI treatment and already at 4 days post-treatment the percentage of cells in S-phase reduced from $55 \%$ to $13 \%$ (data not shown), which was not further enhanced with CQ. At 7 days post-treatment, there was a complete loss of cells in S-phase in DBZ-treated cells. Taken together, these data indicate that $C Q$ enhances the G0/G1 cell cycle block induced by DBZ treatment in T-ALL, but the extent of this cell cycle block differs between T-ALL cell lines.

\section{Chloroquine affects NOTCH1 trafficking, signalling, and turnover in T-ALL}

Since combined treatment of DBZ and CQ showed synergistic effects on T-ALL survival compared to DBZ treatment alone and NOTCH1 mutated T-ALL cells rely on ligand-independent $\mathrm{NOTCH}$ signalling, we questioned whether $\mathrm{CQ}$ directly interfered with $\mathrm{NOTCH} 1$ signalling. As expected, NOTCH1 cleavage at Val1744, resulting in the release of NOTCH1 intracellular domain (N1ICD) and activation of NOTCH1, was blocked at 7 days post-DBZ treatment in ALL-SIL (Figure 2A), HPB- 


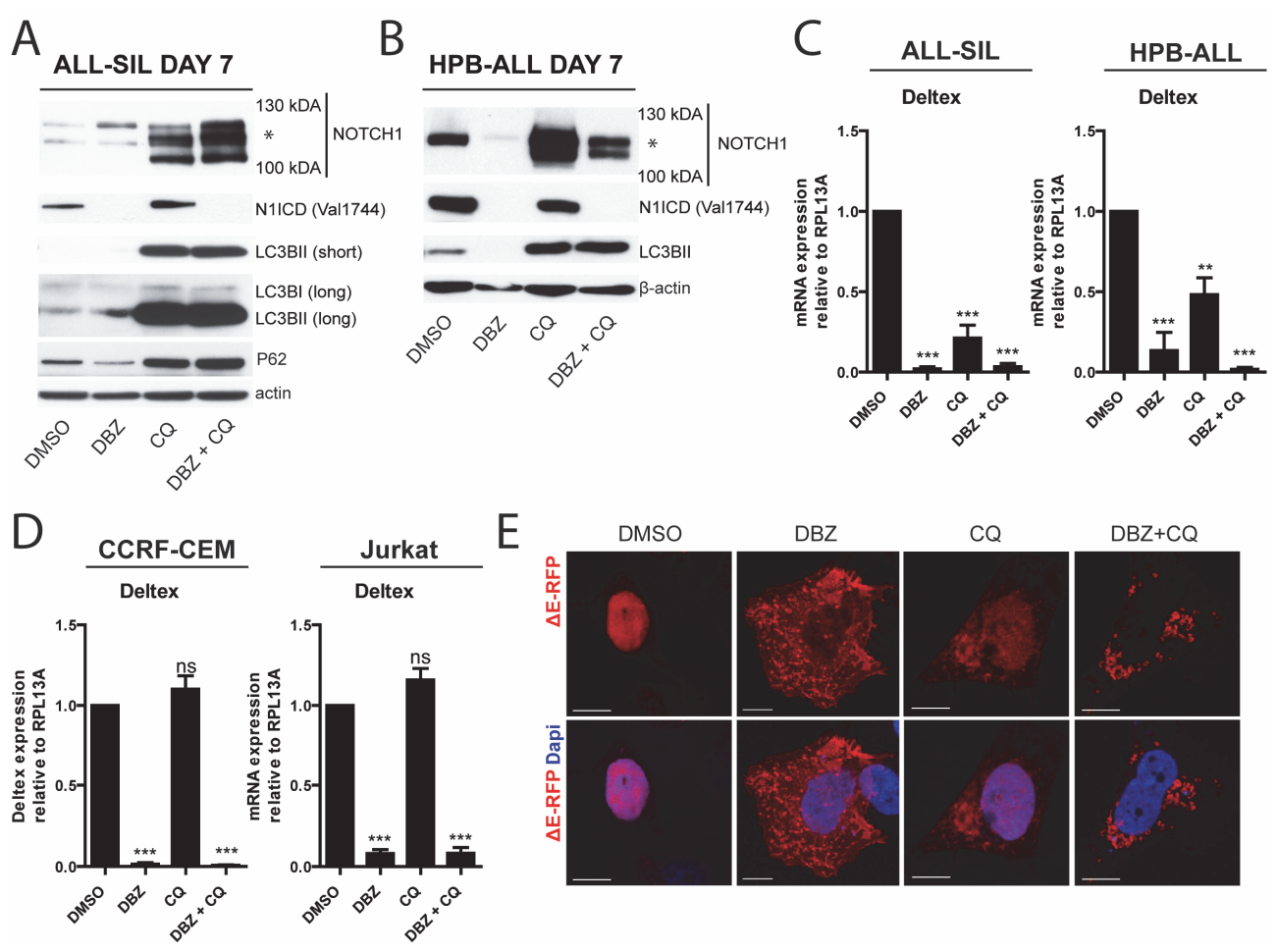

Figure 2. Chloroquine affects NOTCH1 trafficking, localisation, and turnover. A) Immunoblot analysis of LC3BI and II, P62, cleaved NOTCH1, N1ICD (Val1744) and $\beta$-actin protein levels in ALL-SIL cells at 7 days post-treatment. *Asterisk indicates the accumulation of TMIC, NEXT, and NICD NOTCH1 cleaved fragments. B) Immunoblot analysis of LC3B-II, cleaved NOTCH1, N1ICD (Val1744) and $\beta$-actin protein levels in HPB-ALL cells at 7 days post-treatment. *Asterisk indicates the accumulation of TMIC, NEXT, and NICD NOTCH1 cleaved fragments. C) RT-PCR for NOTCH1 target gene Deltex at 4 days post-treatment in GSI-sensitive (ALL-SIL and HPB-ALL) cells. RPL13A was used as housekeeping gene (1way ANOVA (Tukey comparison), ${ }^{* *} P<0.01,{ }^{* * *} P<0.001$, significant compared to DMSO). D) RT-PCR for NOTCH1 target gene Deltex at 4 days post-treatment in GSI-resistant (CCRFCEM and Jurkat) cells and RPL13A (housekeeping gene) (1-way ANOVA (Tukey comparison), ns: non-significant, ${ }^{* * *} P<0.001$, significant compared to DMSO). E) U2OS cells transfected with $\triangle E-R F P$ treated with DMSO, DBZ, $C Q$, and combined treatment for 24 hours, counterstained with Dapi. Scale bar: $10 \mu \mathrm{m}$. LC3B: membrane associated microtubuleassociated protein 1 light chain 3, N1ICD: NOTCH1 intracellular domain. DBZ: $y$-secretase inhibitor dibenzoazepine, CQ: chloroquine. Data and images are representative of three independent experiments and values are expressed in mean \pm SEM. 
ALL (Figure 2B), CCRF-CEM, and Jurkat (Figure S2C) cells. In CQ treated samples N1ICD-Val1744 levels increased in ALL-SIL cells and we also observed a strong increase in membrane-bound $\mathrm{NOTCH} 1$ receptor fragments in $\mathrm{CQ}$-treated and combination treated ALL-SIL, HBP-ALL, Jurkat, and CCRF-CEM cells (Figure 2A, 2B, S2C and S3C). In both GSI-sensitive (Figure 2C) and GSI-resistant (Figure 2D) T-ALL cells expression of the NOTCH1 target gene Deltex was inhibited by DBZ. CQ treatment also reduced Deltex expression but only in GSI-sensitive T-ALL despite high levels of N1ICD (Figure 2C). Notably, in GSI resistant T-ALL cell lines, with only wild-type $\mathrm{NOTCH} 1$ signalling, $\mathrm{CQ}$ treatment did not affect $\mathrm{NOTCH} 1$ target gene expression (Figure 2D), indicating a key difference in the effect of $C Q$ on wild-type and mutant $\mathrm{NOTCH} 1$ signalling.

Since the integrity of the endo/lysosomal compartment can regulate NOTCH1 signalling (Man et al., 2017), we determined if CQ affected NOTCH1 signalling by attenuating endo/lysosomal function in T-ALL. As expected, CQ inhibited lysosomal breakdown of autophagy-related vesicles (autophagosomes), as indicated by accumulation of membrane associated microtubule-associated protein 1 light chain 3 (Atg8) LC3B-II, the golden standard for autophagic flux at 7 days posttreatment (Figure 2A). In addition to LC3B-II, the levels of the autophagosome cargo protein P62 also accumulated in CQ-treated ALL-SIL cells. Similar observations were made in HPB-ALL cells (Figure 2B).

We hypothesized that inhibition of the endosomal and lysosomal pathway by $\mathrm{CQ}$ led to deregulated NOTCH1 trafficking. Therefore, the expression of NOTCH1 at the cell surface was assessed by flow cytometry, using an antibody specific for the extracellular domain of NOTCH1. NOTCH1 receptor availability at the cell surface was significantly increased in ALL-SIL cells treated with GSI compared to DMSO treated cells at 4 days post-treatment (Figure S4C). In contrast, a significant decrease in NOTCH1 extracellular domain expression at the cell surface was found in ALL-SIL cells treated with CQ. When GSI-treatment was combined with CQ the effect of GSI was abolished resulting in a similar NOTCH1 extracellular domain expression compared to vehicle-treated cells. Next, we transfected U2OS cells with a delta-E-RFP ( $\triangle \mathrm{E}-\mathrm{RFP})$ construct, in which the complete extracellular domain of 
NOTCH1 is deleted, but the S2-cleavage site is intact and the PEST domain is exchanged for RFP, which signals ligand-independently, similar to mutated NOTCH1 in leukemic cells. At 24 hours post-treatment, control treated cells showed $\Delta \mathrm{E}-\mathrm{RFP}$ expression exclusively in the nucleus (Figure 2E), while DBZ-treated cells only showed membrane/cytoplasmic $\triangle E-R F P$, as expected. In CQ-treated cells we observed a reduction in nuclear $\triangle E-R F P$ and a cytoplasmic accumulation. When $\mathrm{DBZ}$ and $\mathrm{CQ}$ were combined, no nuclear localisation of the $\triangle \mathrm{E}-\mathrm{RFP}$ was observed and all $\triangle \mathrm{E}$-RFP localized to cytoplasmic vesicle-like structures. Together these data suggest that $\mathrm{CQ}$ treatment leads to $\mathrm{NOTCH} 1$ accumulation in the cytoplasm and this accumulation is enhanced when $C Q$ is combined with $D B Z$ treatment, indicating that $\mathrm{CQ}$ has an effect on NOTCH1 receptor localisation, trafficking, and turnover.

\section{Ligand-independent NOTCH1 trafficking, localisation, and signalling are disturbed by chloroquine}

To further elucidate the effect of $\mathrm{CQ}$ on ligand-independent NOTCH1 trafficking and signalling, we combined $\triangle \mathrm{E}-\mathrm{RFP}$ with the autophagosomal marker GFP-LC3 transfection to see whether $\triangle \mathrm{E}$-RFP co-localized with LC3-positive vesicles. Indeed, GFP-LC3 puncta strongly accumulated in CQ and combination treated U2OS cells (Figure 3A), while no accumulation was observed in control and DBZ-treated cells. Both $C Q$ and combined treatment showed partial co-localisation of $\triangle E-R F P$ and GFP-LC3, however, $\triangle E$-RFP was also detected in LC3-negative vesicles. These data indicate that ligand-independent $\mathrm{NOTCH} 1$ trafficking is disturbed by $\mathrm{CQ}$ treatment and leads to accumulation of $\mathrm{NOTCH} 1$ in autophagosomes, but also in LC3-negative vesicles.

Next, we hypothesized that also N1ICD may accumulate outside of the nucleus in $C Q$ treated cells, as we previously showed high N1ICD protein levels and reduced $\mathrm{NOTCH}$ target gene activation in CQ-treated T-ALL cells. Therefore, we transfected U2OS cells with $\triangle E$-RFP and stained for Val1744 (N1ICD). As expected, $\mathrm{N} 1 \mathrm{ICD}$ accumulated in the nucleus in control-treated cells and co-localized with $\Delta \mathrm{E}-$ RFP expression, which was undetectable in DBZ- or combined-treated cells (Figure 3B). Most interestingly, $\triangle \mathrm{E}-\mathrm{RFP}$ and N1ICD expression did not only co-localize in 
A

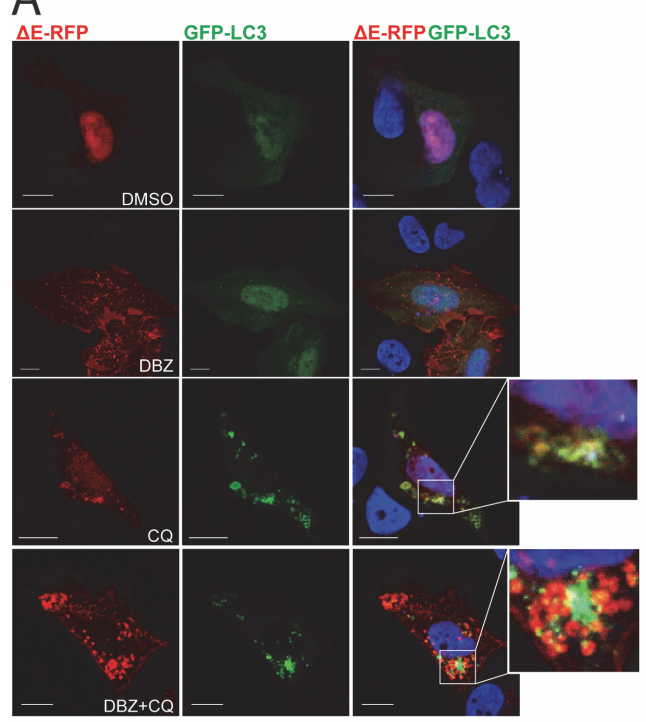

B

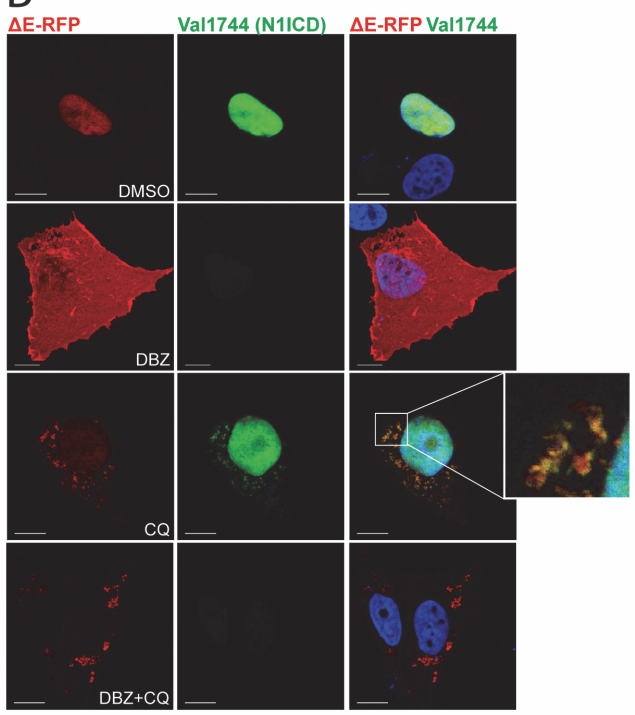

Figure 3. Ligand-independent NOTCH1 trafficking, localisation, and signalling are disturbed by CQ. A) U2OS cells transfected with $\triangle E-R F P$ and GFP-LC3 treated with DMSO, $D B Z, C Q$, and combined treatment for 24 hours, counterstained with Dapi. Magnification is used to show co-localization of $\triangle E-R F P$ and GFP-LC3 indicated by the white square. B) U2OS cells transfected with $\triangle E-R F P$ treated with DMSO, DBZ, CQ, and combined treatment for 24 hours, stained for Val1744 (N1ICD), and counterstained with Dapi. Magnification is used to show co-localization of $\triangle E-R F P$ and Val1744 (N1ICD) indicated by the white square. LC3B: membrane associated microtubule-associated protein 1 light chain 3, N1ICD: NOTCH1 intracellular domain. DBZ: $\gamma$-secretase inhibitor dibenzoazepine, CQ: chloroquine. Scale bar: $10 \mu \mathrm{m}$. Images are representative of three independent experiments.

the nucleus but also in the cytoplasm of CQ-treated cells. Altogether, our data suggest that $\mathrm{CQ}$ affects both ligand-independent $\mathrm{NOTCH} 1$ receptor and N1ICD trafficking and localisation.

\section{Chloroquine induces an accumulation of ROS in T-ALL}

Redox imbalance due to high levels of ROS is associated with DNA damage and cell cycle arrest. CQ has been shown to increase cellular ROS levels in solid cancer cells with defective autophagy-mediated degradation of mitochondria (mitophagy) 
(Rouschop et al., 2009). Flow cytometry analysis showed increased cytoplasmic ROS levels in ALL-SIL cells treated with CQ compared to vehicle treated cells at 4 days post-treatment (Figure 4A). Interestingly, at 7 days post-treatment also DBZtreated cells showed increased levels of cytoplasmic ROS, albeit to a smaller extent than with $\mathrm{CQ}$. Furthermore, combined treatment showed the highest accumulation of cytoplasmic ROS levels. Similar results were obtained in HPB-ALL cells (Figure 4B). CQ treatment alone also induced a 2-fold increase in cytoplasmic ROS levels, similar to ALL-SIL cells. A high dose of DBZ and combined treatment induced a massive ROS accumulation at 7 days post-treatment. Even at a 16-fold lower dose of DBZ significant interaction with $C Q$ in the induction of cytoplasmic ROS levels was obtained. In GSI-resistant cells lines DBZ treatment did not increase cytoplasmic ROS levels (Figure S4D). However, in Jurkat cells CQ treatment significantly increased ROS levels, which was not observed in CCRF-CEM cells.

\section{Chloroquine induces DNA damage and a subsequent activation of the DNA damage response}

High levels of ROS cause activation of the DNA damage response (DDR) and can lead to cell cycle arrest. Flow cytometry analysis of CQ-treated ALL-SIL cells showed increased $\mathrm{YH} 2 \mathrm{AX}$ (a marker of dsDNA breaks) expression by 2-fold at 4 days posttreatment, which was similar when combined with DBZ (Figure 4C). At 7 days posttreatment $\mathrm{yH} 2 \mathrm{AX}$ expression was further increased by $\mathrm{CQ}$ treatment and with the addition of DBZ, $\mathrm{YH} 2 \mathrm{AX}$ expression increased up to 3-fold compared to vehicletreated cells. In HPB-ALL cells, $\mathrm{YH} 2 \mathrm{AX}$ protein expression was also significantly increased when treated with CQ (Figure 4D). DBZ treatment (200 nM) already induced a 2-fold increase in $\mathrm{YH} 2 \mathrm{AX}$ expression, which was not further increased by the combined treatment. Lowering the dose of DBZ (12.5 nM) did not show an increase in $\mathrm{yH} 2 \mathrm{AX}$ expression, however, when combined with $\mathrm{CQ}$ treatment, a significant increase in $\mathrm{YH} 2 \mathrm{AX}$ levels was obtained. GSI-resistant T-ALL cell lines did not show increased $\mathrm{yH} 2 \mathrm{AX}$ expression (Figure S4E). Since we demonstrated elevated levels of ds DNA breaks, we assessed the DDR in CQ-treated cells (Figure 4E). Consistent with the increase in DNA damage, increased levels of 


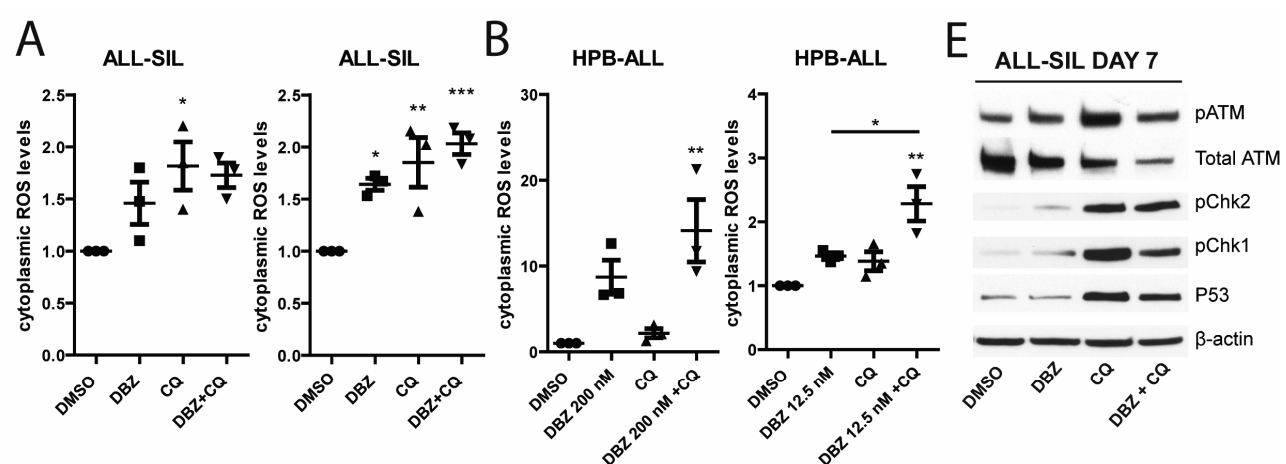

C aLL-SIL

ALL-SIL

D HPB-ALL
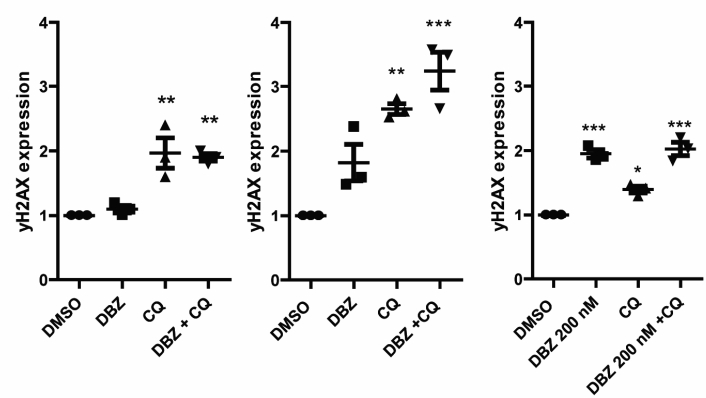

HPB-ALL

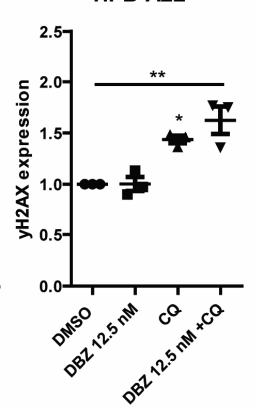

Figure 4. Chloroquine treatment elevates ROS levels and activates the DNA damage response. A) Quantification of cytoplasmic ROS levels in ALL-SIL cells at 4 (left) and 7 (right) days post-treatment analysed by CellROX labelling by flow cytometry (1-Way ANOVA (Tukey comparison), ${ }^{*} P<0.05,{ }^{* *} P<0.01,{ }^{* *} P<0.001$, significant compared to $\left.D M S O\right)$. B) Flow cytometry analysis of cytoplasmic ROS levels in HPB-ALL cells at 7 days post-treatment using a high dose (200 nM, left) and low dose (12.5 nM, right) of DBZ (1-Way ANOVA (Tukey comparison), ${ }^{*} P<0.05,{ }^{* *} P<0.01$, significant compared to DMSO). C) Flow cytometry analysis of $\mathrm{YH} 2 \mathrm{AX}$ expression at 4 (left) and 7 (right) days post-treatment in ALL-SIL cells (1-Way ANOVA (Tukey comparison), ${ }^{* *} P<0.01,{ }^{* * *} P<0.001$, significant compared to DMSO). D) Quantification of $\mathrm{YH} 2 \mathrm{AX}$ expression in HPB-ALL cells at 7 days post-treatment using a high dose (200 nM, left) and low dose (12.5 nM, right) of DBZ (1-Way ANOVA (Tukey comparison), ${ }^{*} P<0.05,{ }^{* *} P<0.01,{ }^{* * *} P<0.001$, significant compared to DMSO). E) DNA damage response protein expression analysis by immunoblot in ALL-SIL cells at 7 days post-treatment. $\beta$-actin was used as loading control. DBZ: $\gamma$-secretase inhibitor dibenzoazepine, CQ: chloroquine, ATM: Ataxia telangiectasia mutated kinase, Chk1: Checkpoint kinase 1, Chk2: Checkpoint kinase 2. Data are representative of three independent experiments and values are expressed in mean \pm SEM. 
phosphorylated ATM kinase (pATM) and downstream cascades pCHK1, pCHK2, and p53 induction were observed in CQ- and combination-treated ALL-SIL cells at 7 days post-treatment. DBZ treatment also showed a slight increase in pATM. Taken together, these data indicate that the DDR is activated, due to induction of DNA damage by $C Q$ treatment, explaining a persistent cell cycle arrest observed in T-ALL cells.

\section{Discussion}

Here, we show for the first time that the clinically used lysosomotrophic drug $C Q$ decreases T-ALL cell viability and proliferation. We demonstrate that $\mathrm{y}$-secretase inhibition induces a potent G0-G1 cell cycle arrest, which is more pronounced upon CQ addition. Whereas GSI treatment predominantly blocks T-ALL proliferation, CQ treatment induces apoptosis, which is synergistic in the combination treatment. The anti-proliferative effect of DBZ is dose-dependent and a general effect of $y$-secretase enzyme inhibition, since three structurally different GSI's show a similar effect. Furthermore, $C Q$ also shows a dose-dependent decrease in cell viability in GSIsensitive T-ALL. When using Bafilomycin, which also blocks lysosomal and endosomal fusion, instead of $C Q$, we obtained comparable effects on T-ALL cell viability and proliferation, albeit less strong. Above-mentioned effects of $D B Z$ and $C Q$ are not observed in GSI-resistant T-ALL cell lines. Interestingly, our in vitro results demonstrate that the addition of $C Q$ to $G S I$ treatment reduces the concentration of GSI required to obtain reduced cell proliferation and viability. Importantly, the interaction between $\mathrm{GSI}$ and $\mathrm{CQ}$ is synergistic with respect to apoptosis induction and allowed a reduction of 16 -fold of the dose of GSI. This strategy may be applied to increase the therapeutic ratio of GSI in T-ALL treatment by reducing GSI-induced gastro-intestinal toxicity while achieving a synergistic anti-proliferative and proapoptotic effect in leukemic cells.

Mechanistically, we show that $C Q$ treatment increases cytoplasmic levels of ROS, implicating a redox imbalance, which might result from an accumulation of mitochondrial mass, indicative of blocking mitophagy, resulting in the accumulation of (damaged) mitochondria, previously shown by our lab in solid tumours (Rouschop 
et al., 2009), but not in T-ALL. Notably, also $\gamma$-secretase inhibition showed increased levels of cytoplasmic ROS in T-ALL, which may result from inhibition of the ROS responsive (Nrf2/Keap1) pathway. This pathway normally neutralizes ROS and is stimulated by NOTCH signalling (Wakabayashi et al., 2014). Increased mitochondrial mass and cytoplasmic ROS levels resulting from CQ treatment were also found in other tumour types, including: glioma and cholangiocarcinoma (Hori et al., 2015; Qu et al., 2017) and induced cytotoxicity in cancer stem cells (Zhang et al., 2015). Together with our data, these results suggest a general dependency of tumour cells on autophagy to maintain their redox balance. Furthermore, DBZ treatment showed a minor increase in DDR activation as expected since $\mathrm{NOTCH} 1$ has been shown to be a negative regulator of the DNA damage response (Kim et al., 2007; Vermezovic et al., 2015). In CQ- and dual-treated T-ALL, we observed increased levels of DNA damage and activation of the DDR that can be responsible for the cell cycle arrest we observed.

Previously, CQ has been shown to activate ATM, in the absence of any DNA damage, resulting in p53-induced cell death in a lymphoma mouse model (Maclean et al., 2008). Indeed, in GSI-sensitive T-ALL cells we observed that $C Q$ treatment increased p53 levels and also increased ds DNA breaks and apoptosis. This is consistent with $C Q$ enhanced p53-induced apoptosis shown in a Myc-induced model of lymphoma (Amaravadi et al., 2007) and CQ-induced secretion of tumour suppressor protein PAR-4 via p53 in mice and cancer patients leading to apoptosis (Burikhanov et al., 2017). Although likely we have not directly demonstrated that ROS are responsible for the increased DNA damage, others have shown that $C Q$ upregulates p53 expression via ROS in which p53 was in turn also able to stimulate ROS formation (Chen et al., 2017). Together, our data are consistent with an important role for $\mathrm{p} 53$ activation induced by $\mathrm{CQ}$ treatment and a complex relationship between $\mathrm{p53}$, autophagy and redox balance in several tumour types.

Besides the promising effects of CQ on GSI-sensitive T-ALL cells observed in this study, CQ was already proposed to have anti-cancer activity in various different tumour types (Maclean et al., 2008; Rouschop et al., 2010; Sasaki et al., 2010) and is being investigated in many clinical trials, to evaluate the safety and 
efficacy of $C Q$ in different types of cancer, including: breast cancer, melanoma, prostate cancer, lung cancer, and colorectal cancer, but not in T-ALL (Shi et al., 2017). Interestingly, $C Q$ was shown to normalize tumour vasculature, thereby increasing perfusion, reducing tumour hypoxia, and increasing the response to treatment (Maes et al., 2014). This vasculature normalization was shown to be dependent on NOTCH1 activation specifically within endothelial cells. Interestingly, in these experiments the action of $C Q$ seemed to be autophagy independent. While we show that $\mathrm{CQ}$ affects autophagic flux, we did not prove that inhibition of autophagy was required for its anti-leukemic effects.

Previous studies showed that NOTCH1 activation by $\gamma$-secretase processing occurs both on the cell surface and in endosomes (Tagami et al., 2008). NOTCH heterodimers at the cell surface expressing T-ALL mutations in the heterodimerization domain are subject to regulated proteolysis (Malecki et al., 2006) by $\mathrm{Zn+}$ dependent ADAM metalloproteases and internalized to intracellular vesicles (van Tetering et al., 2009). Moreover, vesicle acidification was shown to be important, both for physiological ligand-dependent and ligand-independent NOTCH signalling (Vaccari et al., 2010). Therefore, we hypothesized that CQ treatment, which abrogates the fusion between endosomes, autophagosomes, and lysosomes by increasing the intra-vesicular $\mathrm{pH}$, could effectively suppress oncogenic NOTCH1 signalling and therefore decrease cell viability of NOTCH-dependent T-ALL. We demonstrate that $C Q$ treatment results in high levels of both nuclear and cytoplasmic Val1744 cleaved N1ICD. We note that Val1744 cleaved N1ICD co-localized with LC3 in autophagosomes but also in LC3-negative vesicles possibly in endosomes, where $\mathrm{Y}$-secretase has been shown to be more active due to the low $\mathrm{pH}$ environments (Valapala et al., 2013). Moreover, we did observe a decrease in the expression of the downstream target gene Deltex of NOTCH1. This suggests that, together with our finding that $\mathrm{CQ}$ only attenuates Notch target gene expression in GSI-sensitive TALL cell lines, intracellular trafficking of $\mathrm{NOTCH}$ mutated proteins is an important contributor to Notch activity and a therapeutic vulnerability for GSI-sensitive T-ALL. Besides, we also demonstrated increased total levels of the TMIC fragment of $\mathrm{NOTCH} 1$ after $\mathrm{CQ}$ treatment, from which $\mathrm{S} 2$ cleavage has also been shown to be 
pH dependent (Mathews et al., 2010). Interestingly, Bafilomycin also showed accumulation of cleaved N1ICD, but no accumulation of total cleaved NOTCH1 levels, indicating that the effect of $\mathrm{CQ}$ on $\mathrm{NOTCH} 1$ receptor turnover might be not specific to blocking endo-lysosomal fusion in general. Of interest to our work here is that the $\mathrm{Ca}^{2+}$ pump SERCA, previously identified as a therapeutic target for mutated NOTCH proteins (Roti et al., 2013), is also a substrate for Bafilomycin A (Mauvezin et al., 2015). Thus, while CQ and Bafilomycin both block NOTCH signaling they most probably do so in a different manner, which may have resulted in the observed differences in T-ALL cell viability. The exact contribution of each of these mechanisms to blocking $\mathrm{NOTCH}$ needs further investigation but illustrates that there may be multiple distinct intervention points that could be combined for targeting intracellular mutated NOTCH proteins.

Of special interest is the appearance and accumulation of an additional higher molecular Val1744-cleaved NOTCH1 fragment. We speculate that this fragment, which shows a shift of approximately $15 \mathrm{kDa}$, might be due to monoubiquitination. It has been shown previously that mono-ubiquitination of N1ICD is necessary preceding receptor endocytosis (Gupta-Rossi et al., 2004). Together our data suggest that $\mathrm{CQ}$ affects $\mathrm{NOTCH} 1$ receptor turnover and recycling, trapping the $\mathrm{NOTCH} 1$ receptor and its cleaved forms in intracellular vesicles including autophagosomes but also other unidentified vesicles, likely endosomes, and blocking lysosomal degradation of $\mathrm{y}$-secretase cleaved $\mathrm{NOTCH}$ proteins.

Thus, our results support the notion that autophagy may be a central survival mechanism in T-ALL and a therapeutic vulnerability when NOTCH signalling is blocked simultaneously. Recent evidence showed that $\mathrm{y}$-secretase inhibition in TALL leads to a metabolic shutdown, triggering autophagy as a rescue mechanism to support leukemic cell metabolism and proliferation (Herranz et al., 2015). Mice harbouring Atg7 deleted isogenic leukemia's treated with GSI induced a marked antileukemic response in vivo with improved survival. We indeed show that inhibition of autophagy by blockage of lysosomal function has an additional effect on T-ALL cell viability when combined with $\mathrm{NOTCH}$ inhibition. We confirm that autophagy inhibition using CQ in PTEN-negative T-ALL (i.e. Jurkat) does not sensitize GSI-resistant T- 
ALL. This autophagy independence can be explained by activation of AKT signalling (Herranz et al., 2015; Palomero et al., 2007). In addition, in glioblastoma neurospheres GSI inhibition resulted in elevated levels of autophagy and simultaneous inhibition of NOTCH and autophagy led to decreased cell growth, proliferation, and clonogenicity with increased apoptosis in vitro (Natsumeda et al., 2016). Together, these results suggest that tumours with wild-type PTEN are particularly sensitive to small molecule inhibitors of the $\mathrm{NOTCH}$ and autophagy pathways.

Overall, our results reveal a novel application for small molecule inhibitors targeting intracellular vesicles, such as $C Q$ and BAFA, to synergistically enhance the effect of GSI on blocking NOTCH signalling in leukemic cells with NOTCH mutations. While this needs further study one testable hypothesis is that this could be applicable to other NOTCH addicted cancers that are wild-type for PTEN as well. The repurposing of drugs, such as $C Q$, is of interest as developing new drugs is costly and time-consuming, while $C Q$, an already clinically approved drug with minor side effects, may widen the therapeutic window in cancer with activated $\mathrm{NOTCH}$ signalling.

\section{Acknowledgements}

We kindly thank J. Meijerink (Erasmus MC Rotterdam, The Netherlands) for providing all T-ALL cell lines, Bristol-Myers Squibb for providing BMS-906024, and N. Mizushima for providing the pEGFP-LC3 construct. We thank Rafi Kopan (Cincinnati Children's Hospital) for providing Notch1 constructs and J. Cordero (University of Glasgow) for help with creating and characterizing RFP tagged Notch1 cDNA's. This work was supported by the European Research Council (ERC) under the European Community Seventh Framework Program (FP7/2007-2013) ERC starting Grant 208259 and the Kootstra-Talent Fellowship Program 2016-2017 from Maastricht-UMC+.

\section{Conflict of interest}

The authors declare no conflict of interest. 


\section{Author contributorship information}

J.H., R.H., M.S., T.H. and L.B. performed the measurements and analysed the experimental data. J.H. drafted the manuscript and designed the figures under supervision of A.G. and M.V.

A.G., M.V., S.Y. and K.R. contributed to the design and implementation of the research. All authors discussed the results and commented on the manuscript.

\section{Funding}

This work was supported by the European Research Council (ERC) under the European Community Seventh Framework Program (FP7/2007-2013) ERC starting Grant 208259 and the Kootstra-Talent Fellowship Program 2016-2017 from Maastricht-UMC+. 


\section{References}

1. Amaravadi, R. K., Yu, D., Lum, J. J., Bui, T., Christophorou, M. A., Evan, G. I., ThomasTikhonenko, A., and Thompson, C. B. (2007). Autophagy inhibition enhances therapyinduced apoptosis in a Myc-induced model of lymphoma. J Clin Invest 117, 326-336.

2. Bakkenist, C. J., and Kastan, M. B. (2003). DNA damage activates ATM through intermolecular autophosphorylation and dimer dissociation. Nature 421, 499-506.

3. Burikhanov, R., Hebbar, N., Noothi, S. K., Shukla, N., Sledziona, J., Araujo, N., Kudrimoti, M., Wang, Q. J., Watt, D. S., and Welch, D. R. (2017). Chloroquine-Inducible Par-4 Secretion Is Essential for Tumor Cell Apoptosis and Inhibition of Metastasis. Cell reports 18, 508-519.

4. Campbell, R. E., Tour, O., Palmer, A. E., Steinbach, P. A., Baird, G. S., Zacharias, D. A., and Tsien, R. Y. (2002). A monomeric red fluorescent protein. Proc Natl Acad Sci U S A 99, 7877-7882.

5. Chen, P., Luo, X., Nie, P., Wu, B., Xu, W., Shi, X., Chang, H., Li, B., Yu, X., and Zou, Z. (2017). CQ synergistically sensitizes human colorectal cancer cells to SN-38/CPT-11 through lysosomal and mitochondrial apoptotic pathway via p53-ROS cross-talk. Free Radical Biology and Medicine 104, 280-297.

6. Childress, J. L., Acar, M., Tao, C., and Halder, G. (2006). Lethal giant discs, a novel C2domain protein, restricts notch activation during endocytosis. Curr Biol 16, 2228-2233.

7. Degenhardt, K., Mathew, R., Beaudoin, B., Bray, K., Anderson, D., Chen, G., Mukherjee, C., Shi, Y., Gelinas, C., Fan, Y., et al. (2006). Autophagy promotes tumor cell survival and restricts necrosis, inflammation, and tumorigenesis. Cancer Cell 10, 51-64.

8. Ding, Z. B., Hui, B., Shi, Y. H., Zhou, J., Peng, Y. F., Gu, C. Y., Yang, H., Shi, G. M., Ke, A. W., Wang, X. Y., et al. (2011). Autophagy activation in hepatocellular carcinoma contributes to the tolerance of oxaliplatin via reactive oxygen species modulation. Clin Cancer Res 17, 6229-6238.

9. Eng, C. H., Wang, Z., Tkach, D., Toral-Barza, L., Ugwonali, S., Liu, S., Fitzgerald, S. L., George, E., Frias, E., and Cochran, N. (2016). Macroautophagy is dispensable for growth of KRAS mutant tumors and chloroquine efficacy. Proceedings of the National Academy of Sciences 113, 182-187.

10. Ferrando, A. A., Neuberg, D. S., Staunton, J., Loh, M. L., Huard, C., Raimondi, S. C., Behm, F. G., Pui, C. H., Downing, J. R., Gilliland, D. G., et al. (2002). Gene expression signatures define novel oncogenic pathways in $\mathrm{T}$ cell acute lymphoblastic leukemia. Cancer Cell 1, 75-87. 
11. Gupta-Rossi, N., Six, E., LeBail, O., Logeat, F., Chastagner, P., Olry, A., Israël, A., and Brou, C. (2004). Monoubiquitination and endocytosis direct gamma-secretase cleavage of activated Notch receptor. J Cell Biol 166, 73-83.

12. Herranz, D., Ambesi-Impiombato, A., Sudderth, J., Sanchez-Martin, M., Belver, L., Tosello, V., Xu, L., Wendorff, A. A., Castillo, M., Haydu, J. E., et al. (2015). Metabolic reprogramming induces resistance to anti-NOTCH1 therapies in $\mathrm{T}$ cell acute lymphoblastic leukemia. Nat Med 21, 1182-1189.

13. Hori, Y. S., Hosoda, R., Akiyama, Y., Sebori, R., Wanibuchi, M., Mikami, T., Sugino, T., Suzuki, K., Maruyama, M., Tsukamoto, M., et al. (2015). Chloroquine potentiates temozolomide cytotoxicity by inhibiting mitochondrial autophagy in glioma cells. J Neurooncol 122, 11-20.

14. Hu, T., Li, P., Luo, Z., Chen, X., Zhang, J., Wang, C., Chen, P., and Dong, Z. (2016). Chloroquine inhibits hepatocellular carcinoma cell growth in vitro and in vivo. Oncol Rep 35, 43-49.

15. Jaekel, R., and Klein, T. (2006). The Drosophila Notch inhibitor and tumor suppressor gene lethal (2) giant discs encodes a conserved regulator of endosomal trafficking. Dev Cell 11, 655-669.

16. Kabeya, Y., Mizushima, N., Ueno, T., Yamamoto, A., Kirisako, T., Noda, T., Kominami, E., Ohsumi, Y., and Yoshimori, T. (2000). LC3, a mammalian homologue of yeast Apg8p, is localized in autophagosome membranes after processing. Embo j 19, 5720-5728.

17. Kaether, C., Haass, C., and Steiner, H. (2006). Assembly, trafficking and function of gamma-secretase. Neurodegener Dis 3, 275-283.

18. Kim, S. B., Chae, G. W., Lee, J., Park, J., Tak, H., Chung, J. H., Park, T. G., Ahn, J. K., and Joe, C. O. (2007). Activated Notch1 interacts with p53 to inhibit its phosphorylation and transactivation. Cell Death Differ 14, 982-991.

19. Liang, X., Tang, J., Liang, Y., Jin, R., and Cai, X. (2014). Suppression of autophagy by chloroquine sensitizes 5 -fluorouracil-mediated cell death in gallbladder carcinoma cells. Cell Biosci 4, 10.

20. Loehberg, C. R., Thompson, T., Kastan, M. B., Maclean, K. H., Edwards, D. G., Kittrell, F. S., Medina, D., Conneely, O. M., and O'Malley, B. W. (2007). Ataxia telangiectasiamutated and p53 are potential mediators of chloroquine-induced resistance to mammary carcinogenesis. Cancer Res 67, 12026-12033.

21. Maclean, K. H., Dorsey, F. C., Cleveland, J. L., and Kastan, M. B. (2008). Targeting lysosomal degradation induces p53-dependent cell death and prevents cancer in mouse models of lymphomagenesis. J Clin Invest 118, 79-88. 
22. Maes, H., Kuchnio, A., Peric, A., Moens, S., Nys, K., De Bock, K., Quaegebeur, A., Schoors, S., Georgiadou, M., Wouters, J., et al. (2014). Tumor vessel normalization by chloroquine independent of autophagy. Cancer Cell 26, 190-206.

23. Malecki, M. J., Sanchez-Irizarry, C., Mitchell, J. L., Histen, G., Xu, M. L., Aster, J. C., and Blacklow, S. C. (2006). Leukemia-associated mutations within the NOTCH1 heterodimerization domain fall into at least two distinct mechanistic classes. Molecular and cellular biology 26, 4642-4651.

24. Man, J., Yu, X., Huang, H., Zhou, W., Xiang, C., Huang, H., Miele, L., Liu, Z., Bebek, G., and Bao, S. (2017). Hypoxic Induction of Vasorin Regulates Notch1 Turnover to Maintain Glioma Stem-like Cells. Cell stem cell.

25. Mansour, M. R., Linch, D. C., Foroni, L., Goldstone, A. H., and Gale, R. E. (2006). High incidence of Notch-1 mutations in adult patients with T-cell acute lymphoblastic leukemia. Leukemia 20, 537-539.

26. Marks, D. I., Paietta, E. M., Moorman, A. V., Richards, S. M., Buck, G., DeWald, G., Ferrando, A., Fielding, A. K., Goldstone, A. H., Ketterling, R. P., et al. (2009). T-cell acute lymphoblastic leukemia in adults: clinical features, immunophenotype, cytogenetics, and outcome from the large randomized prospective trial (UKALL XII/ECOG 2993). Blood 114, 5136-5145.

27. Mathews, J. A., Gibb, D. R., Chen, B.-H., Scherle, P., and Conrad, D. H. (2010). CD23 Sheddase A disintegrin and metalloproteinase 10 (ADAM10) is also required for CD23 sorting into B cell-derived exosomes. Journal of Biological Chemistry 285, 37531-37541.

28. Mauvezin, C., Nagy, P., Juhász, G., and Neufeld, T. P. (2015). Autophagosome-lysosome fusion is independent of V-ATPase-mediated acidification. Nat Commun 6, 7007.

29. Milano, J., McKay, J., Dagenais, C., Foster-Brown, L., Pognan, F., Gadient, R., Jacobs, R. T., Zacco, A., Greenberg, B., and Ciaccio, P. J. (2004). Modulation of notch processing by gamma-secretase inhibitors causes intestinal goblet cell metaplasia and induction of genes known to specify gut secretory lineage differentiation. Toxicol Sci 82, 341-358.

30. Natsumeda, M., Maitani, K., Liu, Y., Miyahara, H., Kaur, H., Chu, Q., Zhang, H., Kahlert, U. D., and Eberhart, C. G. (2016). Targeting Notch Signaling and Autophagy Increases Cytotoxicity in Glioblastoma Neurospheres. Brain Pathol 26, 713-723.

31. Palomero, T., Sulis, M. L., Cortina, M., Real, P. J., Barnes, K., Ciofani, M., Caparros, E., Buteau, J., Brown, K., Perkins, S. L., et al. (2007). Mutational loss of PTEN induces resistance to NOTCH1 inhibition in T-cell leukemia. Nat Med 13, 1203-1210.

32. Pasternak, S. H., Bagshaw, R. D., Guiral, M., Zhang, S., Ackerley, C. A., Pak, B. J., Callahan, J. W., and Mahuran, D. J. (2003). Presenilin-1, nicastrin, amyloid precursor 
protein, and gamma-secretase activity are co-localized in the lysosomal membrane. J Biol Chem 278, 26687-26694.

33. Qu, X., Sheng, J., Shen, L., Su, J., Xu, Y., Xie, Q., Wu, Y., Zhang, X., and Sun, L. (2017). Autophagy inhibitor chloroquine increases sensitivity to cisplatin in QBC939 cholangiocarcinoma cells by mitochondrial ROS. PLoS One 12, e0173712.

34. Radtke, F., Wilson, A., Stark, G., Bauer, M., van Meerwijk, J., MacDonald, H. R., and Aguet, M. (1999). Deficient T cell fate specification in mice with an induced inactivation of Notch1. Immunity 10, 547-558.

35. Ratikan, J. A., Sayre, J. W., and Schaue, D. (2013). Chloroquine engages the immune system to eradicate irradiated breast tumors in mice. Int J Radiat Oncol Biol Phys 87, 761768.

36. Roti, G., Carlton, A., Ross, K. N., Markstein, M., Pajcini, K., Su, A. H., Perrimon, N., Pear, W. S., Kung, A. L., Blacklow, S. C., et al. (2013). Complementary genomic screens identify SERCA as a therapeutic target in NOTCH1 mutated cancer. Cancer Cell 23, 390-405.

37. Rouschop, K. M., Ramaekers, C. H., Schaaf, M. B., Keulers, T. G., Savelkouls, K. G., Lambin, P., Koritzinsky, M., and Wouters, B. G. (2009). Autophagy is required during cycling hypoxia to lower production of reactive oxygen species. Radiother Oncol 92, 411416.

38. Rouschop, K. M., Van Den Beucken, T., Dubois, L., Niessen, H., Bussink, J., Savelkouls, K., Keulers, T., Mujcic, H., Landuyt, W., and Voncken, J. W. (2010). The unfolded protein response protects human tumor cells during hypoxia through regulation of the autophagy genes MAP1LC3B and ATG5. The Journal of clinical investigation 120, 127.

39. Sasaki, K., Tsuno, N. H., Sunami, E., Tsurita, G., Kawai, K., Okaji, Y., Nishikawa, T., Shuno, Y., Hongo, K., Hiyoshi, M., et al. (2010). Chloroquine potentiates the anti-cancer effect of 5-fluorouracil on colon cancer cells. BMC Cancer 10, 370.

40. Schneider, M., Troost, T., Grawe, F., Martinez-Arias, A., and Klein, T. (2013). Activation of Notch in lgd mutant cells requires the fusion of late endosomes with the lysosome. $J$ Cell Sci 126, 645-656.

41. Sethi, N., Yan, Y., Quek, D., Schupbach, T., and Kang, Y. (2010). Rabconnectin-3 is a functional regulator of mammalian Notch signaling. Journal of Biological Chemistry 285, 34757-34764.

42. Shi, T. T., Yu, X. X., Yan, L. J., and Xiao, H. T. (2017). Research progress of hydroxychloroquine and autophagy inhibitors on cancer. Cancer Chemother Pharmacol 79, 287-294. 
43. Tagami, S., Okochi, M., Yanagida, K., Ikuta, A., Fukumori, A., Matsumoto, N., IshizukaKatsura, Y., Nakayama, T., Itoh, N., Jiang, J., et al. (2008). Regulation of Notch signaling by dynamic changes in the precision of S3 cleavage of Notch-1. Molecular and cellular biology $28,165-176$.

44. Vaccari, T., Duchi, S., Cortese, K., Tacchetti, C., and Bilder, D. (2010). The vacuolar ATPase is required for physiological as well as pathological activation of the Notch receptor. Development 137, 1825-1832.

45. Valapala, M., Hose, S., Gongora, C., Dong, L., Wawrousek, E. F., Samuel Zigler, J., Jr., and Sinha, D. (2013). Impaired endolysosomal function disrupts Notch signalling in optic nerve astrocytes. Nat Commun 4, 1629.

46. van Tetering, G., van Diest, P., Verlaan, I., van der Wall, E., Kopan, R., and Vooijs, M. (2009). Metalloprotease ADAM10 is required for Notch1 site 2 cleavage. J Biol Chem 284 , 31018-31027.

47. Verbaanderd, C., Maes, H., Schaaf, M. B., Sukhatme, V. P., Pantziarka, P., Sukhatme, V., Agostinis, P., and Bouche, G. (2017). Repurposing Drugs in Oncology (ReDO)chloroquine and hydroxychloroquine as anti-cancer agents. Ecancermedicalscience 11, 781.

48. Vermezovic, J., Adamowicz, M., Santarpia, L., Rustighi, A., Forcato, M., Lucano, C., Massimiliano, L., Costanzo, V., Bicciato, S., and Del Sal, G. (2015). Notch is a direct negative regulator of the DNA-damage response. Nature structural \& molecular biology 22, 417-424.

49. Wakabayashi, N., Skoko, J. J., Chartoumpekis, D. V., Kimura, S., Slocum, S. L., Noda, K., Palliyaguru, D. L., Fujimuro, M., Boley, P. A., Tanaka, Y., et al. (2014). Notch-Nrf2 axis: regulation of Nrf2 gene expression and cytoprotection by notch signaling. Molecular and cellular biology 34, 653-663.

50. Weng, A. P., Ferrando, A. A., Lee, W., Morris, J. P. t., Silverman, L. B., Sanchez-Irizarry, C., Blacklow, S. C., Look, A. T., and Aster, J. C. (2004). Activating mutations of NOTCH1 in human T cell acute lymphoblastic leukemia. Science 306, 269-271.

51. Wong, G. T., Manfra, D., Poulet, F. M., Zhang, Q., Josien, H., Bara, T., Engstrom, L., Pinzon-Ortiz, M., Fine, J. S., Lee, H. J., et al. (2004). Chronic treatment with the gammasecretase inhibitor LY-411,575 inhibits beta-amyloid peptide production and alters lymphopoiesis and intestinal cell differentiation. J Biol Chem 279, 12876-12882.

52. Yoshimori, T., Yamamoto, A., Moriyama, Y., Futai, M., and Tashiro, Y. (1991). Bafilomycin A1, a specific inhibitor of vacuolar-type $H(+)$-ATPase, inhibits acidification and protein degradation in lysosomes of cultured cells. J Biol Chem 266, 17707-17712. 
53. Zhang, B. B., Wang, D. G., Guo, F. F., and Xuan, C. (2015). Mitochondrial membrane potential and reactive oxygen species in cancer stem cells. Fam Cancer 14, 19-23.

Supplementary information

Supplementary table 1. RT-PCR primer sequences.

\begin{tabular}{l|ll} 
Gene & \multicolumn{1}{l}{ Forward } & Reverse \\
\hline Deltex & 5'-TGTGCCGCAAGACCAAGAAG-3' & 5'-TCGTAGCCTGATGCTGTGAC-3' \\
RPL13A & 5'-CCGGGTTGGCTGGAAGTACC-3' & 5'-CTTCTCGGCCTGTTTCCGTAG-3'
\end{tabular}




\section{Supplementary figures}

A

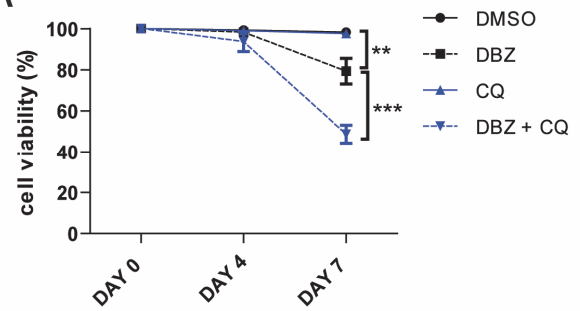

B

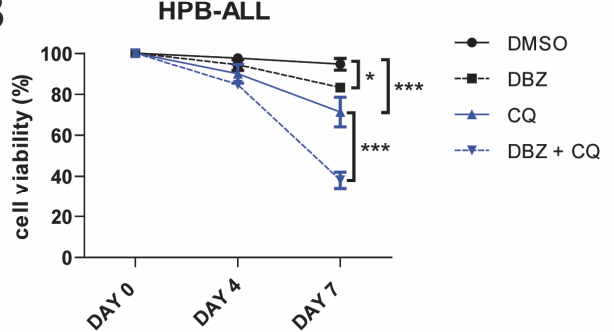

C

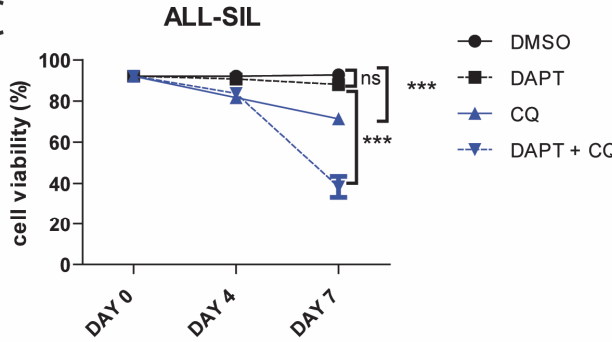

DND41

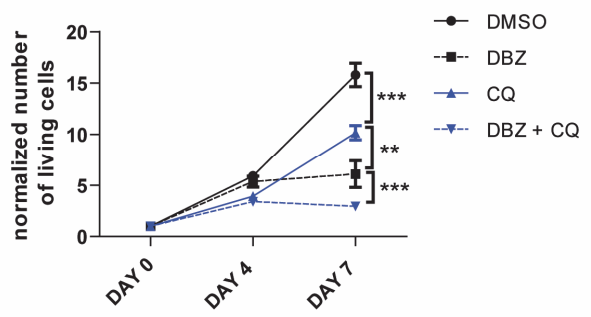

HPB-ALL

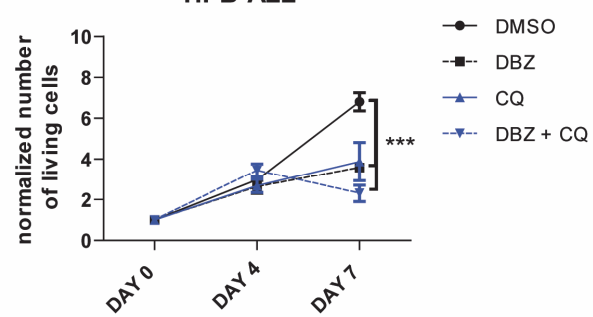

ALL-SIL

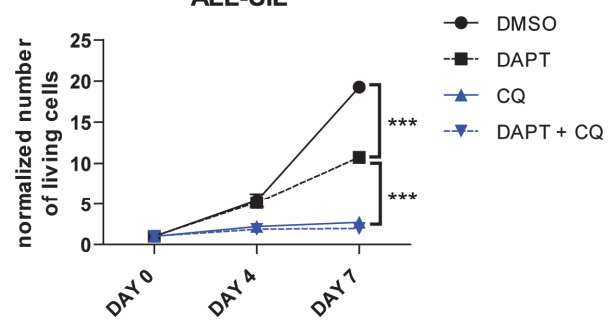

\section{ALL-SIL DAY 7}

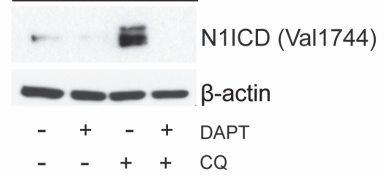

Figure S1. Chloroquine decreases cell viability in GSI-sensitive T-ALL in vitro. A) Time course of GSI-sensitive DND41 cell viability and the number of living cells until 7 days posttreatment (2-Way ANOVA, $\left.{ }^{* *} P<0.01,{ }^{* * *} P<0.001\right)$. B) Time course of GSI-sensitive HPB-ALL cell viability and the number of living cells until 7 days post-treatment (2-Way ANOVA, $\left.{ }^{*} P<0.05,{ }^{* * *} P<0.001\right)$. C) Time course of $A L L-S I L$ cell viability and the number of living cells treated with DMSO, y-secretase inhibitor DAPT, CQ or combined treatment until 7 days posttreatment (2-Way ANOVA, ns: non-significant, $\left.{ }^{* *} P<0.001\right)$. D) Immunoblot analysis of N1/CD 
(Val1744) and $\beta$-actin protein levels in ALL-SIL cells at 7 days post-treatment. DBZ: $\gamma$ secretase inhibitor dibenzoazepine, CQ: chloroquine. Data are representative of three independent experiments and values are expressed in mean \pm SEM.

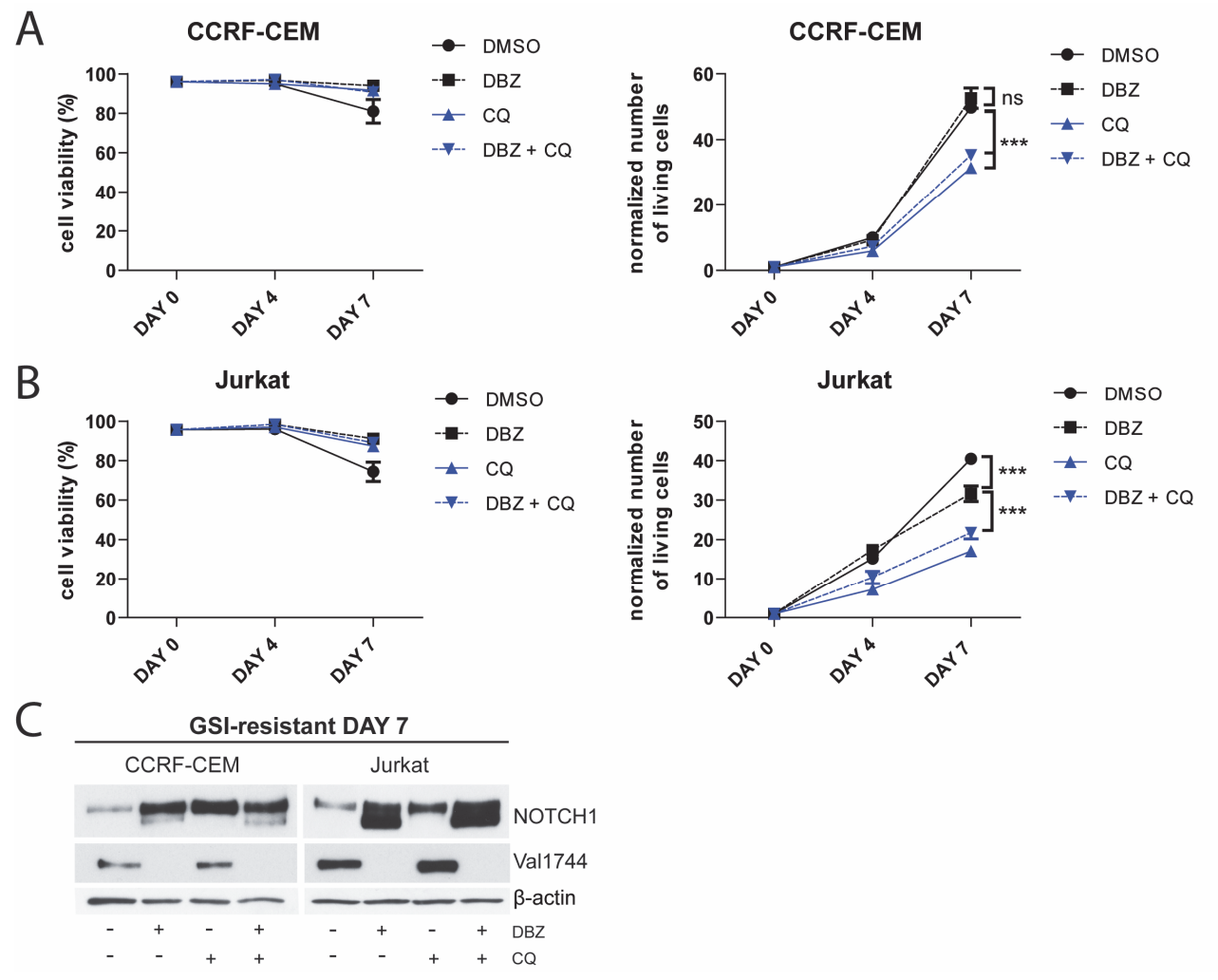

Figure S2. Chloroquine decreases GSI-resistant T-ALL cell proliferation and has no effect cell viability in vitro. A) Time course of GSI-resistant CCRF-CEM cell viability and proliferation until 7 days post-treatment (2-Way ANOVA, ns: non-significant, $\left.{ }^{* * *} P<0.001\right)$. B) Time course of GSI-resistant Jurkat cell viability and proliferation until 7 days post-treatment (2-Way ANOVA, $\left.{ }^{* * *} P<0.001\right)$. C) Immunoblot analysis of cleaved NOTCH1 fragments, N1ICD (Val1744), and $\beta$-actin protein levels in GSI-resistant T-ALL cells at 7 days post-treatment. DBZ: $y$-secretase inhibitor dibenzoazepine, CQ: chloroquine. Data are representative of three independent experiments and values are expressed in mean \pm SEM. 
A

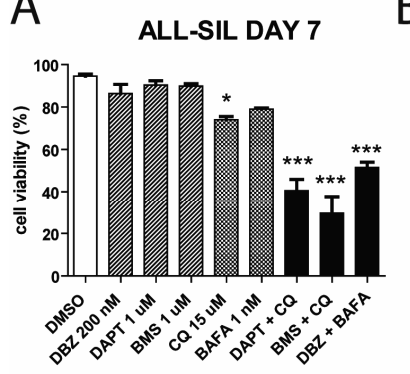

D

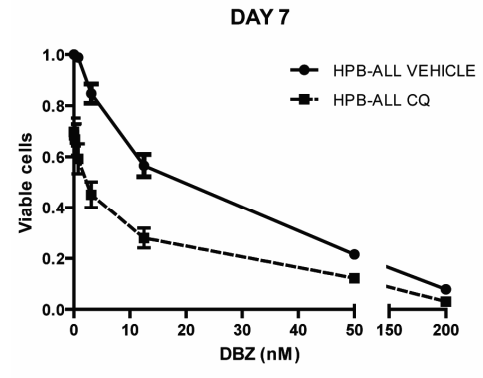

B

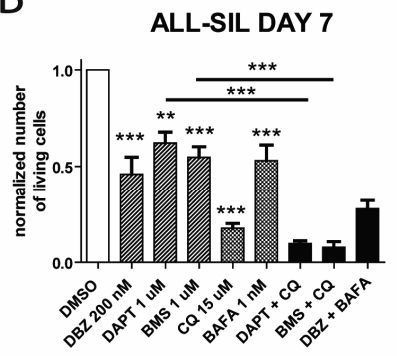

$\mathrm{E}$

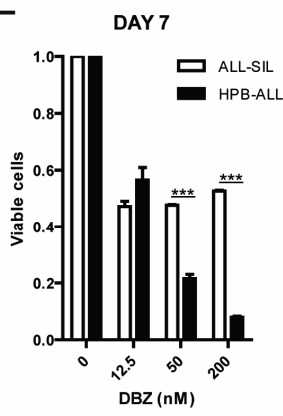

C

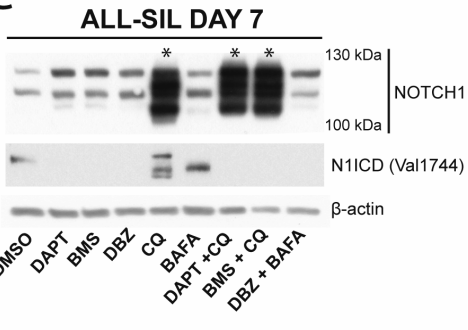

F

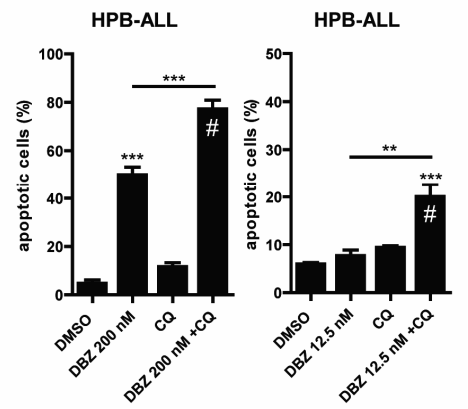

Figure S3. Structurally distinct $y$-secretase inhibitors show similar effects when combined with Chloroquine or Bafilomycin and HPB-ALL cells are more sensitive to GSI in vitro. A) ALL-SIL cell viability treated with DMSO, structurally different $\gamma$-secretase inhibitors (DBZ, DAPT and BMS), CQ, Bafilomycin or combined treatment at 7 days posttreatment (1-Way ANOVA (Tukey comparison), $\left.{ }^{*} P<0.05,{ }^{* * *} P<0.001\right)$. B) The number of living ALL-SIL cells at 7 days post-treatment (1-Way ANOVA (Tukey comparison), ${ }^{* *} P<0.01$, $\left.{ }^{* * *} P<0.001\right)$. C) Immunoblot analysis of cleaved NOTCH1 fragments, N1ICD (Val1744) and $\beta$-actin protein levels in ALL-SIL cells at 7 days post-treatment. *Asterisks indicate the accumulation of TMIC, NEXT, and NICD NOTCH1 cleaved fragments. D) Assessment of viable HPB-ALL cells using CellTiter Glo cell viability assay. HPB-ALL cells were treated once with a dilution range of $D B Z$ with or without $15 \mu M$ of $C Q$ and cell viability was determined at 7 days post-treatment. E) Quantification of the number of viable ALL-SIL and HPB-ALL cells treated with different doses of DBZ (1-Way ANOVA (Tukey comparison), $\left.{ }^{* * *} P<0.001\right)$. F) Quantification of the total percentage of early and late apoptotic HPB-ALL cells based on Annexin $V$ and SYTOX AADvanced flow cytometry at 7 days post-treatment using a high dose (200 nM, left) and low dose (12.5 nM, right) of DBZ (1-Way ANOVA (Tukey comparison), $\left.{ }^{* * *} P<0.001\right)$. "Synergy was determined for both the high (2-Way ANOVA, $\left.{ }^{* *} P<0.01\right)$ and low dose of DBZ (2-Way ANOVA, $\left.{ }^{*} P<0.05\right)$. DBZ: $\gamma$-secretase inhibitor dibenzoazepine, CQ: 
chloroquine. Data are representative of three independent experiments and values are expressed in mean \pm SEM.

A

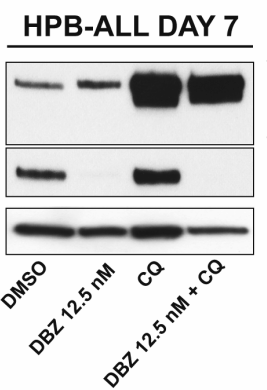

$\mathrm{D}$

CCRF-CEM

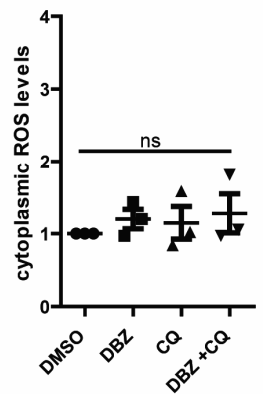

B

CCRF-CEM

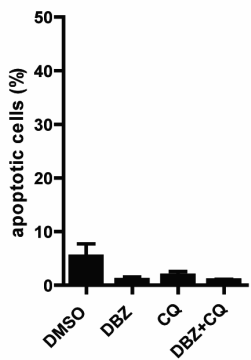

Jurkat

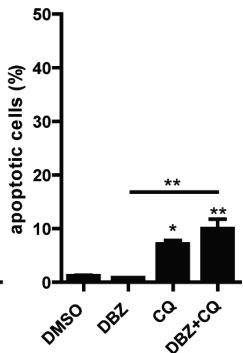

ALL-SIL

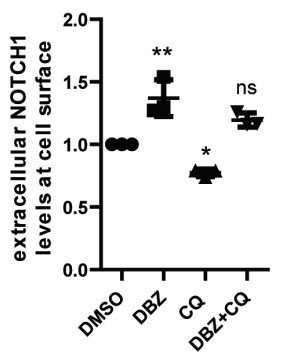

$\mathrm{E}$

Jurkat

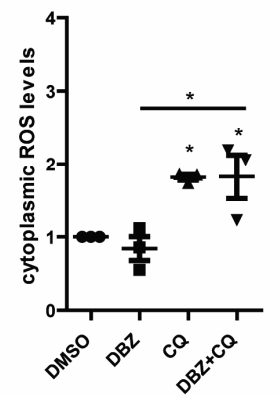

CCRF-CEM

Jurkat
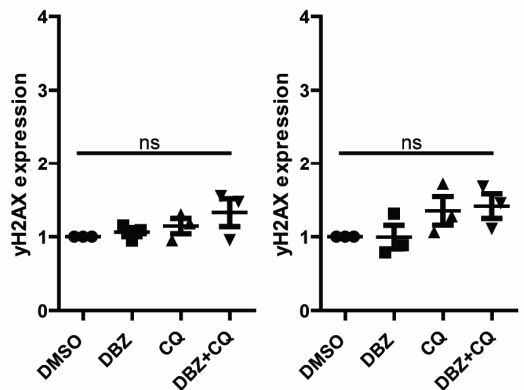

Figure S4. Chloroquine and combined treatment induce no apoptosis and ds breaks in GSI-resistant T-ALL cell lines. A) Immunoblot analysis of cleaved NOTCH1, N1ICD (Val1744) and $\beta$-actin protein levels in HPB-ALL cells treated with a low dose of DBZ (12.5 $n M)$ at 7 days post-treatment. B) Flow cytometry analysis of the total apoptotic GSI-resistant T-ALL cells at 7 days post-treatment (1-Way ANOVA (Tukey comparison), ${ }^{*} P<0.05,{ }^{* *} P<0.01$, significant compared to DMSO). C) Quantification of the mean fluorescent intensity (MFI) normalized to DMSO of NOTCH extracellular domain levels at the cell surface at 4 days posttreatment analysed by flow cytometry (1-Way ANOVA (Tukey comparison), ns: nonsignificant, $\left.{ }^{*} P<0.05,{ }^{*} P<0.01\right)$. D) Quantification of cytoplasmic ROS levels in GSI-resistant cell lines at 7 days post-treatment (1-Way ANOVA (Tukey comparison), ns: non-significant, ${ }^{*} \mathrm{P}<0.05$, significant compared to DMSO). E) Flow cytometry analysis of $\mathrm{YH} 2 \mathrm{AX}$ expression in GSI-resistant T-ALL cell lines at 7 days post-treatment (1-Way ANOVA (Tukey comparison), ns: non-significant). DBZ: $\gamma$-secretase inhibitor dibenzoazepine, CQ: chloroquine, MFI: mean fluorescent intensity. Data are representative of three independent experiments and values are expressed in mean \pm SEM. 


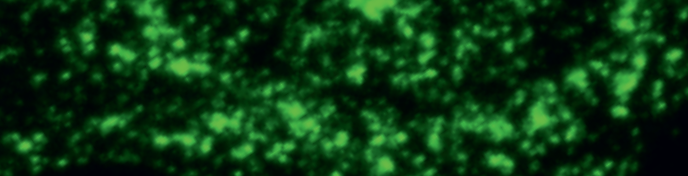

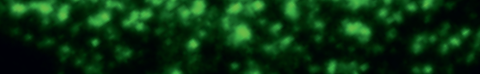

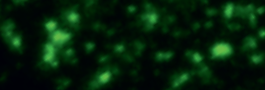

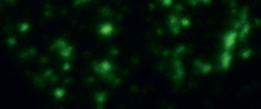

\section{CHAPTER IV}




\section{The isoforms of Divalent me transporter 1 (Dmt1) diff (Aren tarly control Notch-mediatod coll rate decisions}

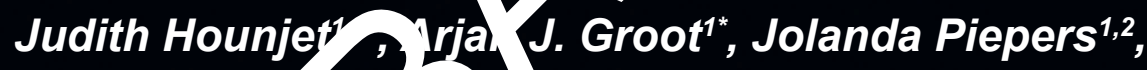
Francesca Ra, in , $m$ R. Kampen', and Marc Vooijs ${ }^{1,2 *}$

${ }^{1}$ Department of A a tion ncology (Maastro), GROW School for Oncology, Maastrich vers ty M.dical Centre+, Maastricht, The Netherlands ${ }^{2}$ Mar iro chn Mranstricht, The Netherlands

*Th auth s share first authorship.

\#corresponding author: marc.vooijs@maastrichtuniversity.nl, Tel: +31 (0)433882912 
1.
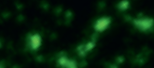

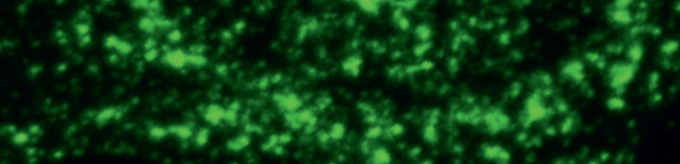

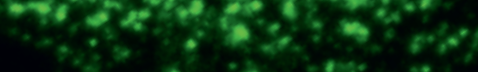

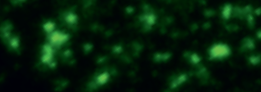

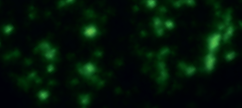

\section{CHAPTER V}




\section{Summary and General discussion}

\section{Judith Hounjet}

Department of Radiation Oncology (Maastro), GROW School for Oncology, Maastricht University Medical Centre+, Maastricht, The Netherlands

Maastro clinic, Maastricht, The Netherlands 

${ }^{4}$

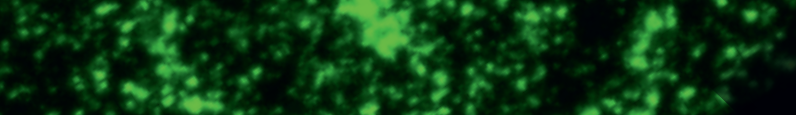

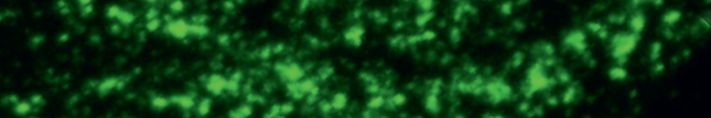

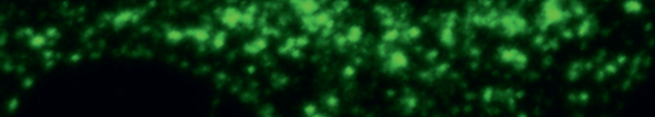

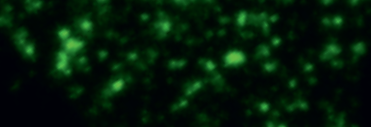

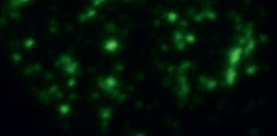


Nederlandse samenvatting 
Kanker is een van de belangrijkste doodsoorzaken wereldwijd. Kanker ontstaat door een ongecontroleerde celgroei die veroorzaakt wordt door mutaties in het DNA. Door deze mutaties worden eiwitten die groei stimuleren meer aangemaakt en actiever, terwijl eiwitten die groei normaalgesproken onderdrukken, worden geremd. Hierdoor ontstaat een disbalans, waardoor cellen ongeremd kunnen delen en er een tumor kan vormen, groeien en uitzaaien. Notch signalering is een communicatie mechanisme tussen twee cellen dat celgroei, cel differentiatie en celdood reguleert tijdens de ontwikkeling en in bijna alle volwassen weefsels. Cellen in deze organen dienen continu vernieuwd te worden en hebben dus celgroei signalen nodig voor het correct uitvoeren van hun functie.

Notch is een receptor eiwit dat aan het cel oppervlak zit. Om actief te worden, moet de Notch receptor binden aan een ligand eiwit op een naastgelegen cel. Vervolgens wordt de Notch receptor door enzymen in meerdere fragmenten geknipt. Dit zorgt ervoor dat het actieve deel van de Notch receptor vrijkomt van het cel oppervlak en via het cytoplasma van de cel zich verplaatst naar de celkern, waar het celgroei aanzet. Recent onderzoek wijst echter uit dat Notch activiteit ook wordt beïnvloed door de locatie van de (actieve) Notch receptor fragmenten in de cel. Deze fragmenten van de Notch receptor worden in de cel getransporteerd in kleine blaasjes, zogenaamde "vesicles". Afhankelijk van het soort vesicle, waarin de Notch fragmenten zich bevinden, is Notch actief of inactief. Dit zal uiteindelijk bepalend zijn voor het gedrag van de cel en welke verandering deze ondergaat.

Kankeronderzoek wijst uit dat de Notch signaal route vaak ontregeld en actief is in kankercellen en dus de groei van deze kanker cellen stimuleert. Hoge activiteit van Notch komt in verschillende soorten kanker voor, onder andere in: leukemie, borstkanker en longkanker. Het merendeel van de beschreven mutaties in de Notch signaal route komen voor in een specifiek soort leukemie van de T-cellen. In andere soorten kanker komen mutaties in het Notch eiwit sporadisch voor, hoewel Notch wel heel actief is. Waarom de activiteit van de Notch signaal route zo hoog is in veel 
soorten kanker is nog onduidelijk. Doordat veel tumoren hoge Notch activiteit laten zien, en deze activiteit afhankelijk is van de enzymen die Notch knippen, zijn remmers van deze enzymen getest als potentiële anti-kanker behandelingen. Hoewel deze Notch remmers effectief zijn in het bestrijden van kankercellen, laten ze ook nadelige effecten zien in normale weefsels. Dit komt doordat Notch remmers niet alleen Notch activiteit blokkeren in kankercellen, maar ook in de normale weefsels. Hierdoor worden Notch remmers (tot op heden) niet gebruikt in de behandeling van kankerpatiënten.

Het doel van dit promotie onderzoek was het bestuderen van activiteit van het Notch eiwit in kanker en normale cellen en het vinden van de verschillen tussen beiden. Deze verschillen zouden we kunnen benutten om nieuwe kankerbehandelingen te ontwikkelen die meer specifiek tumor cellen aanpakken zonder de normale weefsels aan te tasten. Deze kankerbehandelingen zouden dus effectiever kunnen zijn in het bestrijden van de kankercellen met minder schadelijke bijwerkingen.

In hoofdstuk II van dit proefschrift geven we een overzicht van de actuele kennis op het gebied van Notch activiteit in de fruitvlieg (waarin de Notch signaal route oorspronkelijk is ontdekt en waarin veel van de huidige kennis over Notch activiteit is verkregen) en in zoogdieren. In deze review vatten we samen waarom de regulatie van Notch activiteit door andere eiwitten in vesicles belangrijk is in de Notch signaal route. Afhankelijk van het soort vesicle waarin Notch zich bevindt, kan Notch activiteit worden geactiveerd of geremd. Er zijn aanwijzingen dat deze manier van Notch activatie meer wordt gebruikt door kankercellen ten opzichte van normale cellen. $\mathrm{Er}$ is echter meer onderzoek nodig om deze hypothese te bewijzen en hiervoor een gerichte therapeutische aanpak te ontwikkelen. In de toekomst zouden met meer kennis geneesmiddelen, die de activatie van Notch in vesicles verstoren, mogelijk Notch activiteit nog specifieker kunnen remmen in kankercellen. 
In hoofdstuk III van dit proefschrift beschrijven we een studie gedaan op leukemie cellen, die hoge Notch activiteit vertonen, met chloroquine (in combinatie met Notch remmers). Chloroquine is een geneesmiddel dat wordt gebruikt in het voorkomen en behandelen van malaria, maar wordt ook in steeds meer in klinische studies getest in de behandeling van verschillende soorten kanker. Chloroquine verstoort namelijk het transport via vesicles in de cel. We laten zien dat de combinatie van chloroquine en Notch remmers zorgt voor een afname van groei en een toename van celdood van de leukemie cellen, doordat chloroquine DNA schade veroorzaakt, die de leukemie cellen niet meer kunnen repareren. Daarnaast zorgt chloroquine ervoor dat het actieve Notch deel ophoopt in vesicles in de cel, maar niet meer actief is. Tenslotte laten we zien dat door het combineren van chloroquine met Notch remmers een lagere dosis van Notch remmers nodig is om hetzelfde anti-leukemie effect te krijgen ten opzichte van een behandeling met alleen Notch remmers. In theorie zou dit de bijwerkingen van deze Notch remmers in de behandeling leukemiepatiënten sterk kunnen verminderen.

In hoofdstuk IV van dit proefschrift hebben we Dmt1, een eiwit dat verschillende metalen waaronder ijzer transporteert, geïdentificeerd als een nieuwe regulator van Notch activiteit. Dmt1 kan in vier verschillende vormen in de cel voorkomen: Dmt1a, Dmt1a+, Dmt1b- en Dmt1b+. We laten zien dat het remmen van de Dmt1- vormen Notch activiteit remt, terwijl het remmen van de Dmt1+ vormen Notch activiteit juist stimuleert. Als alle vormen van Dmt1 inactief zijn in een cel wordt Notch ook inactief. Hoewel het mechanisme hierachter nog niet helemaal duidelijk is, laten we zien dat verlies van Dmt1 leidt tot een verstoord transport van vesicles en dat dit hoogstwaarschijnlijk ook verantwoordelijk is voor de inactiviteit van de Notch signaal route.

In hoofdstuk V van dit proefschrift geven we een samenvatting van onze bevindingen en bediscussiëren we de eventuele mechanismen die Notch, chloroquine en Dmt1 samenbrengen. Daarnaast veronderstellen we hoe deze 
nieuwe kennis toegepast kan worden in de behandelingen van kankerpatiënten en welke uitdagingen we nog dienen te overbruggen met toekomstig kankeronderzoek om te komen tot meer kanker specifieke behandelingen, die effectiever zijn met minder bijwerkingen. 

${ }^{4}$

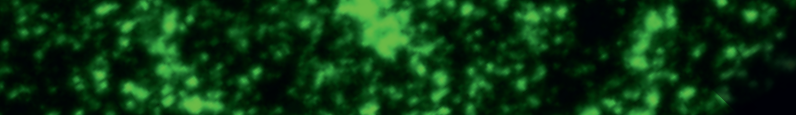

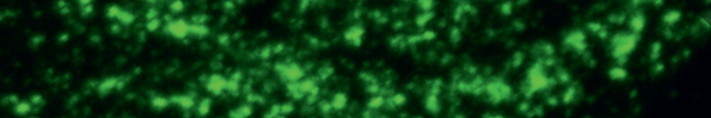

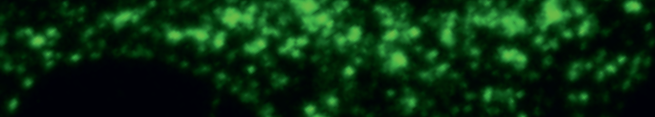

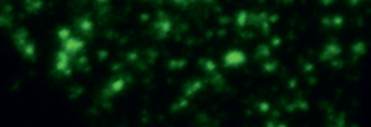

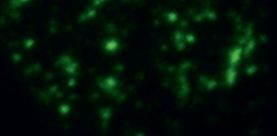




\section{Reflection}

Scientific and social impact 


\section{Scientific impact}

Cancer is one of the leading causes of death world-wide and cancer research gained extensive insights in tumor biology over the last decades. Cancer research showed that cancer cells make "smart" use of common mechanisms normal cells use for their homeostasis to sustain their growth and survival. Therefore, the main struggle in fighting cancer is to not damage normal cells while killing cancer cells. Although these mechanisms used for cell growth by cancer and normal cells seem similar, cancer cells show some modifications in these mechanisms, that maybe exploited to achieve a higher tumor selectivity of treatments. Anti-cancer drugs targeting these differences may kill cancer cells specifically, with less normal tissue damage.

Notch is a protein, which is highly active throughout mammalian development and in adult tissues, and frequently deregulated in a broad range of human cancers, sustaining cancer stem cell survival, tumor progression, and treatment resistance. Therefore, the use of Notch inhibitors appears to be a promising anti-cancer treatment. Unfortunately, Notch inhibitors also target Notch signaling in normal tissues and therefore have shown limited anti-cancer effects due to dose-limiting toxicities in normal tissues, including the intestine and skin. To achieve effective targeting of Notch in cancer tissues only, differences in Notch signaling in cancer and normal cells need to be studied to obtain a better understanding in the vulnerabilities of cancer cells regarding to Notch activity.

In this thesis, we provide novel insights in the regulation of Notch activity, which will support future cancer research in developing novel Notch targeting therapeutic strategies for anti-cancer treatments. First, we have shown that Notch in cancer cells uses intracellular trafficking by vesicles as a major source of its activity, while normal cells are not dependent to the same extent on this activation mode. Therefore, targeting the intracellular routing of Notch and thus limiting its activation in cancer cells, may result in specific cancer cell killing, without affecting Notch activity in normal tissues.

In addition, we discovered that Dmt1, a general metal transporter, is a novel regulator of Notch activity. We hypothesize that Dmt1 also affects Notch signaling by disrupting its activation in intracellular vesicles. Notch and iron addiction are common 
features of various cancers. Therefore, the development of isoform specific inhibitors of Dmt1 may provide a double edged sword in cancer treatment. First, inhibition of Dmt1 may block Notch activity and secondly reduce iron uptake, which cancer cells are more dependent on to sustain their growth and tumor progression compared to normal cells. In addition, various types of cancer may benefit from this therapeutic approach. However, more research is required to demonstrate the safety and efficacy of isoform specific Dmt1 inhibitors. Furthermore, proper patient selection will be required since not all cancer cells are driven by high levels of Notch activity and iron. Unfortunately, bringing novel drugs towards clinical use in cancer patients may require several decades of research. First, the safety and efficacy of the novel treatment needs to be proven in vivo and subsequently in clinical trials, which will be also expensive.

An effective anti-cancer treatment which may be faster, cheaper, and show low toxicity may be repurposing existing drugs. In this approach, drugs that are already approved for the treatment of other human diseases find other off-labelapplications. In this thesis, we show that chloroquine, a FDA-approved drug, which is used for the prevention and treatment of malaria, is effective in killing leukemic cells, which are 'addicted' to Notch activity. Moreover, we show that when combining chloroquine with Notch inhibitors this requires a lower dose of Notch inhibitors to gain the same anti-leukemic efficacy in vitro compared to either monotherapy. Although these data need to be confirmed in in vivo studies, combining Notch inhibitors with chloroquine in the treatment of leukemia may result in an increased anti-leukemic efficacy with decreased toxicity, due to the requirement of a lower dose of Notch inhibitors.

Future cancer research may benefit of combining fundamental research with repurposing drugs. Fundamental research will discover novel vulnerabilities of cancer cells, which do not affect normal cells. Using repurposed drugs, which target these vulnerabilities, instead of developing new drugs, may lead to faster and cheaper testing of the efficacy and safety of these drugs in cancer patients and may take less time to be implemented as approved anti-cancer treatments. 


\section{Social impact}

In addition to the benefit of our findings for future research, this knowledge may also benefit cancer patients. In this thesis, we highlight the importance of fundamental research, which will strengthens our insights in cancer biology and supports the development of more specific anti-cancer therapies. Patients will benefit from treatments, which target cancer cells more specifically, as these treatments will probably lead to increased anti-cancer activity and low toxicity. Therefore, these treatments will provide a high chance of more durable responses and increased patient survival with enhanced quality of life. In addition, repurposing drugs, which are currently used to treat other human diseases, will be probably faster implemented as anti-cancer treatments for patients compared to developing new drugs, which is expensive and may take decades to be implemented in the clinic. Less expensive anti-cancer treatments may be more accessible for minorities and developing countries increasing the equality of healthcare globally.

Over the last decades drug repurposing has been successful in several cases. The most well-known repurposed drug maybe sildenafil, marketed as Viagra, which was originally developed for the treatment of angina, a pain in the chest induced by oxygen shortage in the heart muscle, however, became the leading drug in the treatment of erectile dysfunction. A more recent success story of repurposing drugs is aspirin. Aspirin is a commonly used pain killer, however, showed to be also effective in the prevention of cardiovascular disease and colorectal cancer. Currently, several drugs are being tested as repurposed drugs in clinical trials to obtain better, faster, and less expensive treatments.

Although cancer is one of the leading causes of death world-wide, we are currently facing an additional threat to the survival of the human species: the coronavirus (COVID-19 or SARS-CoV-2) pandemic. Severe cases of COVID-19 infection result in acute respiratory syndrome and systemic organ failure, which is currently increasing mortality world-wide. Therefore, there is an unmet demand for effective treatments, however, developing novel drugs or vaccines is very expensive and most importantly time-consuming. Therefore, currently a broad range of FDAapproved drugs are tested for their anti-viral activity against COVID-19 in clinical 
trials, including: chloroquine, dexamethasone, and others. Although chloroquine treatment in COVID-19 patients is currently not recommended, dexamethasone treatment shows promising results. A large randomized controlled clinical trial in the UK showed that dexamethasone was effective in increasing survival in patients with severe COVID-19 disease. Currently, the main hypothesis on the cause of severe COVID-19 disease is an inappropriate immunological response. Dexamethasone is a corticosteroid, which is currently used to suppress inflammation in several diseases. This example shows the importance of finding effective treatments fast by combining fundamental research with repurposed drugs, which are currently improving COVID-19 patient survival and reducing their symptoms. Thus, this approach may also benefit both cancer research and patients in the future. 

${ }^{4}$

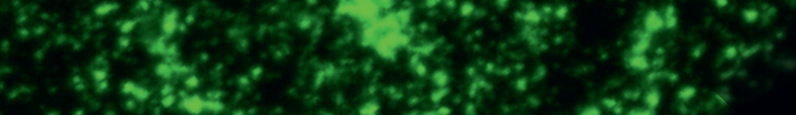

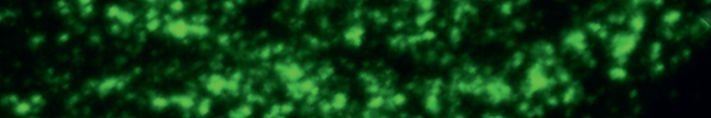

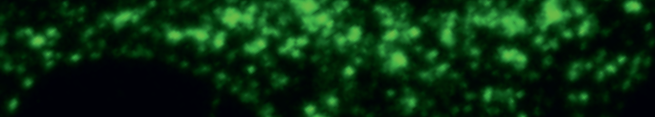

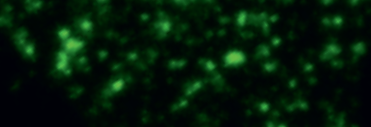

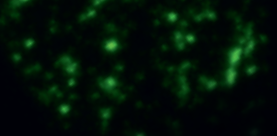




\section{Acknowledgements \\ Dankwoord}


Het is gelukt! Wat is het een spannende, maar ook hele leuke tijd geweest. Een $\mathrm{PhD}$ traject volbrengen is niet gemakkelijk, maar in combinatie met een cyber hack, een coronacrisis, een klushuis en tuin en nog even tussendoor trouwen extra spannend!

Eigenlijk wist ik al na mijn stage op de afdeling Radiotherapie dat ik hier graag als PhD student aan het werk zou gaan. Op de radiotherapie afdeling heerst een leuke sfeer, wordt een breed spectrum aan kankeronderzoek uitgevoerd, staat de deur van iedereen altijd open en zijn je collega's wel altijd in voor een grapje. Dit alles samen heeft ervoor gezorgd dat dit mooie boekje hier nu ligt waar ik trots op ben. Natuurlijk kan ik dit niet allemaal alleen. Daarom wil ik graag iedereen even in het zonnetje zetten die mij hierbij heeft geholpen:

Marc, als mijn promoter natuurlijk het allerbelangrijkst in het maken van dit proefschrift. Volgens mij heb ik het je niet altijd even gemakkelijk gemaakt. Ik was aan het begin van mijn PhD namelijk nogal koppig (en soms misschien nog steeds) over de onderzoeksprojecten die ik graag zou willen uitvoeren. Normaal is de weg voor een $\mathrm{PhD}$ student vrij "straight forward". Je solliciteert op $\mathrm{PhD}$ posities die beschikbaar zijn (dus waar de professor al budget voor heeft binnengehaald). Bij ons ging dit ietsje anders. Je had al twee projecten opgestart waar ik heel graag aan wilde werken tijdens mijn $\mathrm{PhD}$ traject, maar hier was helaas nog geen financiering voor. Je bood me aan om een ander $\mathrm{PhD}$ traject te starten waarbij de financiering al rond was. Dit was echter niet het $\mathrm{PhD}$ traject dat ik voor ogen had en besloten we er samen voor te gaan: we gingen een Kootstra Talent Fellowship schrijven. Daar zat ik dan in Zuid-Frankrijk tijdens een cursus "Development of Marine Organisms" in de late uurtjes te werken aan onze fellowship, maar dat was het helemaal waard, want we werden uitgenodigd voor een interview. Ik kan me nog goed herinneren dat ik in de wachtruimte zat rond de vroege avond, starend naar een witte muur en wat was ik zenuwachtig. Wat was ik dan ook blij dat jij even later om de hoek kwam en met me hebt gekletst totdat ik naar binnen mocht. Hierdoor was ik veel relaxter, ging de presentatie goed en was de Kootstra Talent Fellowship een paar maanden later "in the pocket"! In de opvolgende jaren heb jij nog hard moeten werken om de verdere 
drie jaar van mijn $\mathrm{PhD}$ traject te financieren. Marc, bedankt dat je mij hiermee zo goed hebt geholpen en ik daardoor de onderzoeksprojecten heb mogen uitvoeren waar mijn passie en hart ligt. Tijdens mijn PhD stond ook jouw deur altijd open en kon ik altijd bij je terecht met interestante, maar vaak ook onverklaarbare resultaten, en we kwamen er altijd samen weer uit. Ik heb heel veel geleerd in de afgelopen vier jaar op meerdere vlakken. Jij hebt ervoor gezorgd dat ik nu als onafhankelijk onderzoeker aan het werk kan. Waar ik je ook erg dankbaar voor ben is dat je me de mogelijkheid hebt gegeven om aan meerdere congressen deel te nemen. Deze waren erg leerzaam, vooral ons uitje naar Cyprus. Wat was dat een superleuke en leerzame meeting! Ik heb hiervan echt genoten!

Arjan, wat ben jij toch ongelofelijk enthousiast over je werk en wat is dat aanstekelijk! Hoewel ik je soms hebt moeten remmen in je enthousiasme (vooral omdat er maar 24 uur in een dag zitten) heb je er echt voor gezorgd dat ik enthousiast bleef over mijn projecten, ook als het even allemaal niet zo werkte als dat we hadden gehoopt. Samen zijn we ervoor gegaan en de aanhouder wint! Uiteindelijk kregen we alle "killerexperimenten" werkend! Daarnaast heb ik je in de afgelopen vier jaar goed leren kennen als persoon en weet ik dat je ontzettend lief, zorgzaam en attent bent. Je bent echt een goede vriend geworden en mocht dan ook zeker niet ontbreken op onze trouwerij samen met Jenny. Je hebt een fantastisch liedje gemaakt voor onze bruiloft! Lieve Arjan, ik wens jou en je prachtige gezin (Jenny, Maya en Max) het allerbeste en nog heel veel gelukkige, liefdevolle en gezonde jaren samen! Liefs, Juudje-parapluutje.

Daarnaast wil ik graag mijn leescommissie: voorzitter Prof. dr. L. de Windt, Prof. dr. M. Maurice, Dr. A. Romano, en Prof. dr. F. Reggiori bedanken voor de tijd en moeite die zij hebben gestoken in het evalueren van mijn proefschrift en hun opbouwende feedback.

Ook wil ik mijn lieve paranimfen: Rianne en Jolanda bedanken. Lieve dames, wat hebben wij leuke momenten beleefd! Jullie hebben ervoor gezorgd dat ik altijd met plezier naar mijn werk kwam en voor de nodige gezelligheid en humor! Wat hebben we in de kweek flink wat afgekletst (wij vrouwen kunnen gelukkig twee dingen 
tegelijkertijd) en de half 12 tosti bij jullie was ook altijd even gezellig. Natuurlijk loopt niet altijd alles op rolletjes bij het uitvoeren van kankeronderzoek dus er was ook het nodige geklaag, maar dat lucht op en zorgt voor nieuwe motivatie. Ook buiten werktijd hebben we het erg gezellig gehad, lekker op bezoek bij elkaar, lekker bubbelen en cocktailtjes drinken bij Judith (ook als het best wel koud is buiten), gezellig knuffelen met Jurre, etc. Lieve Rianne, ik wens jou, Marco, Jurre en je kleine kruimeltje nog heel veel gezonde, gelukkige en liefdevolle jaren samen in jullie mooie huis in Eijsden! Lieve Jolanda, ik wens jou en Sjeng ook het allerbeste en heel veel gezonde, gelukkige en liefdevolle jaren samen. Ik hoop dat jullie snel jullie droomhuis vinden en dat het niet al te ver weg is, zodat Rianne en ik nog gezellig op bezoek kunnen komen $:$ :

Bovendien wil ik natuurlijk mijn lieve PhD collega's bedanken met wie ik in hetzelfde schuitje zat. Lieve Damiënne, bedankt voor onze gezellige kletsmomentjes en je super lieve attenties, zoals een geweldige poezenmok $;$ : Ik wens je heel veel succes met het afronden van je $\mathrm{PhD}$ en je verdere studie! Je wordt een top arts!

Dear Jon, thank you for all the talks and laughs we had. You are a wonderful person and a very hard worker! I wish you all the best for the future!

Beste Alex, nog even volhouden en dan heb jij ook een prachtig proefschrift! Bedankt voor je gezelligheid, humor en vooral voor jouw interesse in Tito. Ik zal hem binnenkort toch maar eens meenemen!

Beste Maikel, ik wens je veel succes met het afronden van je PhD. Dat gaat je zeker lukken! Bedankt voor onze gezellige momenten samen en onze humoristische appjes. Ik wens je het allerbeste voor de toekomst en ik weet zeker dat je een top oncoloog zult worden!

Lieve Lydie, ik leerde je kennen in het lab als technician, maar nu ben je ondertussen ook al zelf PhD student! Superknap dat je deze uitdaging aangaat! Je bent een hele lieve meid en ik wens je al het geluk, want dat verdien je! Het organiseren van de teambuilding was erg gezellig samen met jou en ik heb er dan ook erg van genoten! 
Ik wens je veel succes met het verdere verloop van je $\mathrm{PhD}$, maar dat gaat je zeker lukken!

Beste Relinde, hoewel ik je natuurlijk niet zo heel vaak zag, was het altijd gezellig als je weer eens bij ons op kantoor voorbijkwam. Ik vond het dan ook erg leuk dat je er met onze teambuilding bij was!

Dear Anaís, Joel, Èlia, Annemarie, Ying and Yanchao, I wish you all good luck with you PhD projects! Do not only work hard but also try to enjoy it!

Ook wil ik graag de $\mathrm{PhD}$ studenten die gepromoveerd zijn tijdens mijn $\mathrm{PhD}$ traject bedanken. Beste Raymon, het was altijd gezellig met jou op het PhD kantoor. Bedankt voor al je humor en gezelligheid, ook tijdens onze bezoekjes bij elkaar thuis. Ik wens jou en Maaike het allerbeste voor de toekomst en nog heel veel gezonde, gelukkige en liefdevolle jaren samen en natuurlijk ook voor Henk, Hai en Huub ;)

Dear Eloy, Venus and Veronica, it was a real pleasure working with you at Maastrolab. I really enjoyed all our talks and the fun we had. I wish you all the best!

Daarnaast wil ik ook graag onze technicians en Carla bedanken. Lieve Carla, dank je wel voor al je administratieve hulp, maar ook de gezellige babbeltjes die we hebben gehad. Je staat altijd klaar voor iedereen en houdt het lab draaiende!

Lieve technicians, lieve Kim Savelkouls, Natasja, Rianne Biemans en Jolanda, wat zich niet iedereen beseft is dat jullie echt ons lab draaiende houden. Van stomme apparaten die besluiten om op vakantie te gaan tot de coronamaatregel uitvoeringen. Wat werken jullie hard om ons werk in het lab mogelijk te maken en wat ben ik daar dankbaar voor! Als er iets kapot gaat maken jullie er meteen werk van, zodat het zo snel mogelijk weer werkt. Door jullie harde werk krijgen wij onze vriezer lades weer open, zijn al onze cellijnen mycoplasma vrij, worden onze kweekkasten elk jaar netjes onderhouden, etc., etc. Lieve Technicians, hartstikke bedankt! Jullie zijn echte toppers! Kim, bedankt voor je hulp en je heerlijke carnavalsmuziek en enthousiasme! Natasja, dank je wel voor je hulp in het lab en de gezellige lunches! 
Dan zijn er natuurlijk ook nog onze Postdocs in het lab die ik graag wil bedanken. My dear Lorena, since the start of my PhD you were my lovely neighbor and I miss you every day since you left our office. You are a lovely Italian friend and I really enjoyed working next to you. I wish you all the best for the future! Marijke, wat is het toch leuk om een medekattenmoeder in het lab te hebben $\odot$. Het is altijd leuk om met jou even gezellig te kletsen over alle gekke dingen die onze katjes uithalen. Je bent een toponderzoeker! Je bent altijd zeer geïnteresseerd in alle projecten en stelt altijd goede, kritische vragen. Superleuk dan ook dat je weer terug bent in ons team! Marike, wat is het jammer dat we jou moeten missen in het lab, maar wie weet zien we je nog eens terug $:-$ Je bent een toponderzoeker en een kei in mitochondriaal onderzoek! Tom Keulers, dank je wel voor je luisterend oor en je hulp en interesse. Je staat altijd klaar voor je collega's en bent een zeer kritische en goede onderzoeker. Ik heb veel van je geleerd en het was ook altijd erg gezellig met jou op kantoor. Tom, Anne, Lenn en Tymo, ik wens jullie gezin nog heel veel gezonde, gelukkige en liefdevolle jaren samen $\odot$. Ala, thank you for your kindness and your critical questions during our meetings. I wish you all the best for the future! Rianne Vaes, je bent een lieve en gezellige collega en ik wens je veel succes met je positie als postdoc en het afronden van je promotie. Tom and Ola, thank you for your kindness. I wish you both all the best and good luck with your research. Niall, thank you for the nice chats we had. I hope you can enjoy much of the Netherlands soon!

Beste Kasper, dank je wel dat ik altijd even bij je langs mocht komen om iets te vragen over chloroquine, vesicle trafficking of interessante maar onverklaarbare data. Beste Ludwig, dank je wel dat ook altijd jouw deur openstond en ik altijd bij je terecht kon met mijn vragen.

Lieve Kim Kampen, wat ben jij een toponderzoeker! Hoewel we in het begin een beetje aan elkaar moesten wennen, hadden we al snel in de gaten dat wij een topteam vormen! Kim, wat heb ik genoten van onze brainstormsessies! Wat kan ik lekker met jou theorieën verzinnen over hoe dat nu zit met die Dmt1 isovormen. Hoewel je eigenlijk pas aan het einde van mijn PhD project bij ons in het lab aan het 
werk ging, ben ik je zeer gaan waarderen als slimme en lieve collega. Lieve Kim, ik wens jou en Juul het allerbeste voor de toekomst.

Dear Franscesca, although we only worked together for a few months I really appreciate all the effort you made in analyzing the data of the screen, all your database searches on Dmt1, your help with generating the organoid data and your feedback on the Dmt1 paper. Thank you very much for your interest our projects. I wish you all the best!

I would also like to thank the Microscopy CORE Lab of the FHML/M4I Institute of Maastricht University for their scientific and technical support in the electron microscopy work. Dear Carmen, Kevin, Willine and Hans, thank you for all your help, support, enthusiasm and interest in our projects. I really enjoyed our collaboration.

Dan is er nog een collega die ook niet mag missen: Eddy. Lieve Eddy, wat ben jij toch altijd positief en vrolijk. Eddy tovert bij iedereen een lach op het gezicht, ook al is het een minder zonnige dag! Bedankt voor alle leuke babbels die we hebben gehad en natuurlijk voor het opsporen van al mijn bestellingen $(;)$

Lieve Fleur, wat ken ik jou al lang en wat ben jij een lieve vriendin! Vroeger speelden we nog met de barbies en de Playmobil. Tegenwoordig gaan we gezellig lunchen, lekker een ijsje eten in Ulvend, een avondje uiteten of gezellig bloemetjes plukken in de plukweide. Je denkt aan alles en bent een super lieve, knappe en gezellige meid! Ik verheug me altijd weer op onze dates die eigenlijk wel altijd een paar uur in beslag nemen aangezien we altijd zoveel hebben om over te kletsen. Toen ik druk was met het schrijven van mijn proefschrift stond $\mathrm{jij}$ als een echte cheerleader voor me klaar en werden onze gezellige dates even uitgesteld. Je bent een schat! Ik hou van jou lieve Fleur en ik weet zeker dat ergens die lieve, knappe, gezellige en humorvolle prins op het witte paard op jou wacht. Ik wens je het allerbeste voor de toekomst!

Dan is er natuurlijk ook nog mijn lieve familie die mij altijd ondersteunt. Mijn lieve zusje Esther, jij staat altijd voor je "kleine" zusje klaar en bent heel attent. Als je kleine zusje naar Parijs vertrekt voor negen maanden kom je gezellig bij haar op 
bezoek, ook al zijn die vieze Parijse metro's echt niets voor jou. Met je lieve kaartjes, cadeautjes en bezoekjes sta je altijd voor me klaar en heb je ook een fantastisch vrijgezellenfeest georganiseerd en was je een top ceremoniemeester op onze bruiloft. Ook als Romeo en ik vier katten adopteren sta je voor ons klaar en kom je met alle liefde onze vier schatjes verzorgen, zodat Romeo en ik toch een weekje op vakantie kunnen gaan naar ons geliefde Fuerteventura. Lieve Esther, ik bof maar met zo een zus als jou! Ik wens jou, Twan, Mitch en ome Dokus het allerbeste voor de toekomst en dat jullie nog heel veel jaren van elkaar mogen genieten in goede gezondheid en met veel liefde.

Lieve Paps en Mams, zonder al jullie hulp, liefde en ondersteuning was dit proefschrift er natuurlijk ook nooit geweest. Jullie vonden die achten en negens eigenlijk allemaal niet nodig, maar het is altijd leuk om te zien hoe trots jullie aan iedereen vertellen dat ik mijn PhD "doe" in kankeronderzoek. Ja, binnenkort kunnen jullie mij aanspreken met Dr. Judith (-). Paps en Mams, jullie staan altijd achter mij, als ik besluit om voor mijn studie negen maanden naar Parijs te gaan, helpen jullie graag en komen jullie mij zelfs met de Thalys opzoeken en leven jullie een paar dagen mee in mijn Parijse leventje. Ook als Romeo en ik besluiten een klushuis te kopen staan jullie vanaf de sleuteloverdracht voor ons klaar en helpen jullie elk weekend weer mee aan alle Kelmondse feestjes. Wat bof ik toch met jullie! Lieve Paps en Mams, dank je wel voor alles! Ik hoop dat ik nog heel lang van jullie mag genieten!

Lieve Anjolie en Wiel, wat bof ik toch met zo'n lieve schoonouders als jullie! Jullie staan altijd voor Romeo en mij klaar, zijn altijd geïnteresseerd in alles wat we doen en helpen in het weekend weer altijd mee aan de Kelmondse feestjes. Dank je wel voor alles!

Felina, Tito, Neo en Diego, thuiswerken was nooit saai met jullie vier om me heen. Jullie zorgen voor de nodige ontspanning en inspiratie tijdens de stressvolle weken van het schrijven van mijn proefschrift. Zoals Sigmund Freud al zei: "Time spent with cats is never wasted". Hoewel het natuurlijk klinkt als het meest onlogische idee: op vakantie verliefd worden op een jong straatkatje, haar laten opvangen in een tijdelijke 
opvang op het eiland in verband met de quarantaine, waarbij een paar dagen voor haar vlucht blijkt dat ze uiteindelijk moeder wordt. Maar een moederkat en haar drie kittens overlaten vliegen van Fuerteventura naar Kelmond was zeker een van onze beste beslissingen! Poesjes, met jullie in huis is er altijd iets te doen en we kunnen altijd weer lachen om jullie gekke streken.

Dan blijft er tenslotte natuurlijk nog de belangrijkste person in mijn leven over: mijn lieve Romeo. Als ik jou zou willen bedanken voor alles wat je voor me hebt gedaan kan ik wel een heel boek schrijven. We hebben elkaar 11 jaar geleden ontmoet en wat is er in die tijd veel gebeurd. Je was een wildvreemde persoon voor mij toen ik je 11 jaar geleden in de Peppermill ontmoette en dat was toch wel een beetje eng. Maar na een paar weken inclusief vele uren op msn, afspraakjes en gekkigheid was het al snel duidelijk: jij bent het voor mij! Jij bent mijn beste vriend, mijn maatje, mijn medekomiek, mijn gekke Romeo, mijn alles! Samen met jou kan ik alles aan, je staat altijd achter me, jij accepteert mijn gekke buien en doet gewoon lekker mee, laat de rest van de wereld maar denken wat zijn dat voor een twee gekken, wij zijn zielsgelukkig met elkaar! Jij maakt me iedere dag aan het lachen om iets stoms of iets kleins. Misschien vinden mensen je wel stil in een groep en kijk je liever de kat uit de boom, voor mij ben je perfect! En bij mij ben je dat helemaal niet, haha, soms klets je me zelfs de oren van de kop af!

Wat hebben wij in de afgelopen vier jaar hard gewerkt om ons droomhuis te verwezenlijken. "Het wordt altijd beter dan dat het was". Het is prachtig aan het worden lieve Romeo en wat werk jij hier hard voor! Je hebt ooit gezegd dat het leuk zou zijn als er twee van mij waren. Dan kon de een het huishouden doen en kon je met de ander leuke dingen ondernemen. Je voegde eraan toe dat ik dit als een compliment moest zien. Je bent me er een! Een groot huishouden kost veel tijd en je doet dan ook je best om een goede huisman te zijn. Zo kwam ik al een pen tegen in de wasmachine, werd de tafel gedekt met twee messen en heb je een keer toch echt wel iets te pittig gekookt. Al doende leert men toch? 
Naast de liefde voor elkaar is er natuurlijk ook onze liefde voor de poesjes. Terwijl andere mensen heerlijk genieten van hun welverdiende vakantie regelen wij de adoptie van een toch wel heel snoezig straatkatje op Fuerteventura, die dan ook nog bevalt van drie kittens. "Och dan nemen we ze toch gewoon alle vier", zegt Romeo dan. Wat was dat een goede beslissing. Nu genieten we elke dag van elkaar en onze vier schatjes. Al 11 jaar samen en ik had er geen seconde van willen missen, lieve Romeo. Mijn Romeo, ik hou van jou en dat zal ook altijd zo blijven ...

If I lay here, if I just lay here, would you lie with me and just forget the world? 

${ }^{4}$

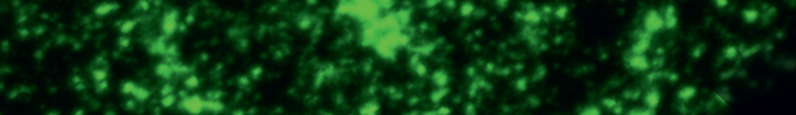

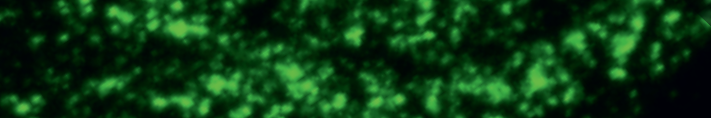

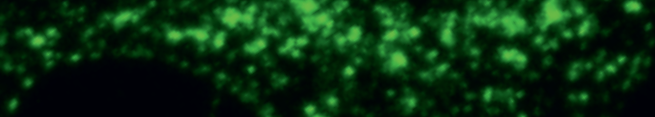

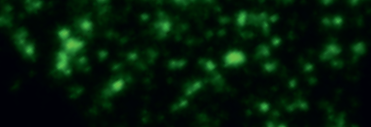

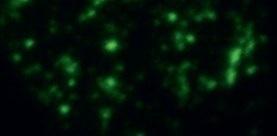


Curriculum Vitae 


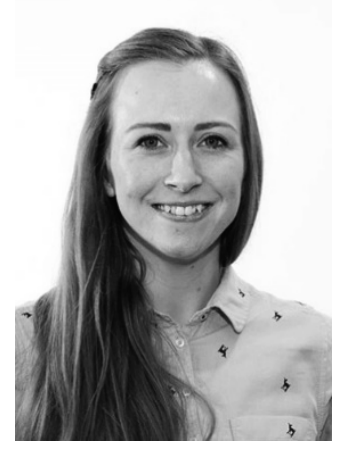

Judith Hounjet was born on February $10^{\text {th }} 1993$ in Kerkrade, the Netherlands. In 2011, she obtained her secondary school degree at Sophianum SG in Gulpen, the Netherlands. In 2011, she started her bachelor degree in Molecular Life Sciences at Maastricht University, the Netherlands. During her bachelor studies she was member of the $10 \%$ best performing students of all bachelor programs in the Netherlands (Socrates International Honour Society). In addition, she joined a Maastricht Research based learning for excellence (Marble+) program, which focused on developing competences and presentation skills. She performed her bachelor internship under the supervision of Dr. M.R. Losen at the Department of Psychiatry and Neuropsychology (Maastricht University, the Netherlands) where she studied the generation of antibodies from immortalized B cells in Myasthenia Gravis. In addition, she performed a voluntary internship during the summer holidays to extent her lab skills and completed her bachelor degree with cum laude in 2014.

She continued her academic studies starting a master in Biomedical Sciences at the Transnational University Limburg (a collaboration between Hasselt University and Maastricht University) in 2014. During her first year she performed her junior internship under the supervision of Prof. Dr. M.A.G.G. Vooijs at the Department of Radiotherapy at Maastricht University. She studied the role of Divalent metal transporter 1 (Dmt1) on Notch signaling and extended her internship voluntarily during the summer holidays. She obtained an Erasmus fellowship to complete her Master studies with an one-year exchange with the Université Pierre et Marie Curie (UPMC) in Paris, France, were she belonged to the top 3 students of her class. During this one-year exchange she performed two extracurricular courses, including the International Developmental Biology course at the UPMC and the Development of Marine Organisms course at the Marine station of Villefranche-sur-Mer (Sorbonne Université) in France. She completed her senior research laboratory internship under the supervision of Dr. A. J. Bardin at the Department of Stem cells and Tissue Homeostasis at the institute Curie in Paris, performing a molecular analysis of 
spontaneous intestinal stem cell neoplasia in aged male Drosophila. She completed her Master degree in 2016.

In 2016, Judith was granted the Kootstra Talent Fellowship to start her PhD research under the supervision of Prof. Dr. M.A.G.G. Vooijs at the Department of Radiotherapy at Maastricht University. During her PhD she studied the effect of combined treatment of chloroquine and Notch inhibitors in human T-ALL cells and investigated the role of the isoforms of Dmt1 on Notch trafficking and signaling. During her PhD she supervised students in the lab, taught as a tutor the course Growth and Development II ( $2^{\text {nd }}$ year bachelor of Medicine, Maastricht University), gave poster presentations at the EACR25 and KWF Cancer Biology meeting in 2018, and an oral presentation at the Notch targeting in Cancer conference in Cyprus. 

${ }^{4}$

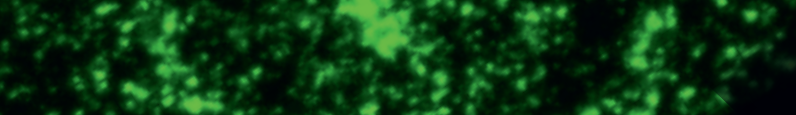

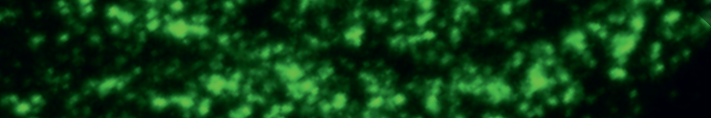

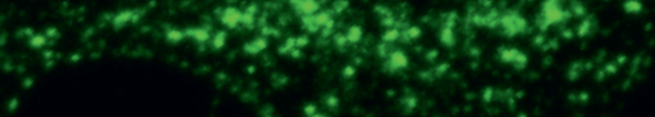

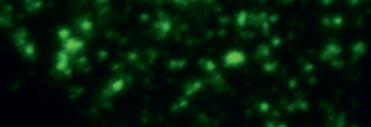

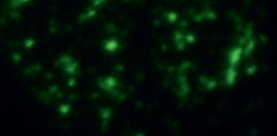




\section{List of publications}




\section{Publications}

Giuranno L, Wansleeben C, lannone R, Arathoon L, Hounjet J, Groot AJ, Vooijs M. NOTCH signaling promotes the survival of irradiated basal airway stem cells. Am J Physiol Lung Cell Mol Physiol. 2019 Sep 1;317(3):L414-L423. doi:

10.1152/ajplung.00197.2019. Epub 2019 Jul 19.

Hounjet J, Habets R, Schaaf MB, Hendrickx TC, Barbeau LMO, Yahyanejad S, Rouschop KM, Groot AJ, Vooijs M. The antimalarial drug chloroquine sensitizes oncogenic NOTCH1 driven human T-ALL to $Y$-secretase inhibition. Oncogene. 2019 Jul;38(27):5457-5468. doi: 10.1038/s41388-019-0802-x. Epub 2019 Apr 9.

Nogales-Gadea G, Saxena A, Hoffmann C, Hounjet J, Coenen D, Molenaar P, Losen M, Martinez-Martinez P. Generation of Recombinant Human IgG Monoclonal Antibodies from Immortalized Sorted B Cells. J Vis Exp. 2015 Jun 5;(100):e52830. doi: $10.3791 / 52830$.

Hounjet, JSJM. Myasthenia gravis: a pathologic approach. Biomedical and health sciences research: FHML MaRBLe Research Papers. 2014;3:306-18.

\section{In preparation}

Hounjet J, Groot, AJ, Piepers J, Rapino F, Kampen KR, Vooijs M. The isoforms of Divalent metal transporter 1 (Dmt1) differentially control Notch-mediated cell fate decisions.

Hounjet $\mathbf{J}$, Vooijs M. The role of intracellular trafficking of Notch receptors in Notch signaling activation (review) 


\section{Presentations}

$28 / 06 / 2019$

Notch targeting in cancer meeting, Konnos Bay, Cyprus (oral)

$22 / 11 / 2018$

GROW Science Day, Maastricht University, The Netherlands (poster)

$19 / 11 / 2018$

KWF Cancer Biology meeting, Lunteren, The Netherlands (poster)

$01 / 07 / 2018$

European Association for Cancer Research (EACR25), Amsterdam, The Netherlands (poster)

$28 / 05 / 2018$ GROW Pizza meeting, Maastricht University, The Netherlands (oral)

$17 / 11 / 2017$ GROW Science Day, Maastricht University, The Netherlands (poster)

\section{Awards}

Kootstra talent fellowship (2016)

First year of funding to start $\mathrm{PhD}$ program

Erasmus fellowship (2015)

One-year exchange with Université Pierre et Marie Curie (UPMC) in Paris, France Member of Socrates International Honour Society (2014) $10 \%$ of best performing students of all bachelor programs in the Netherlands 